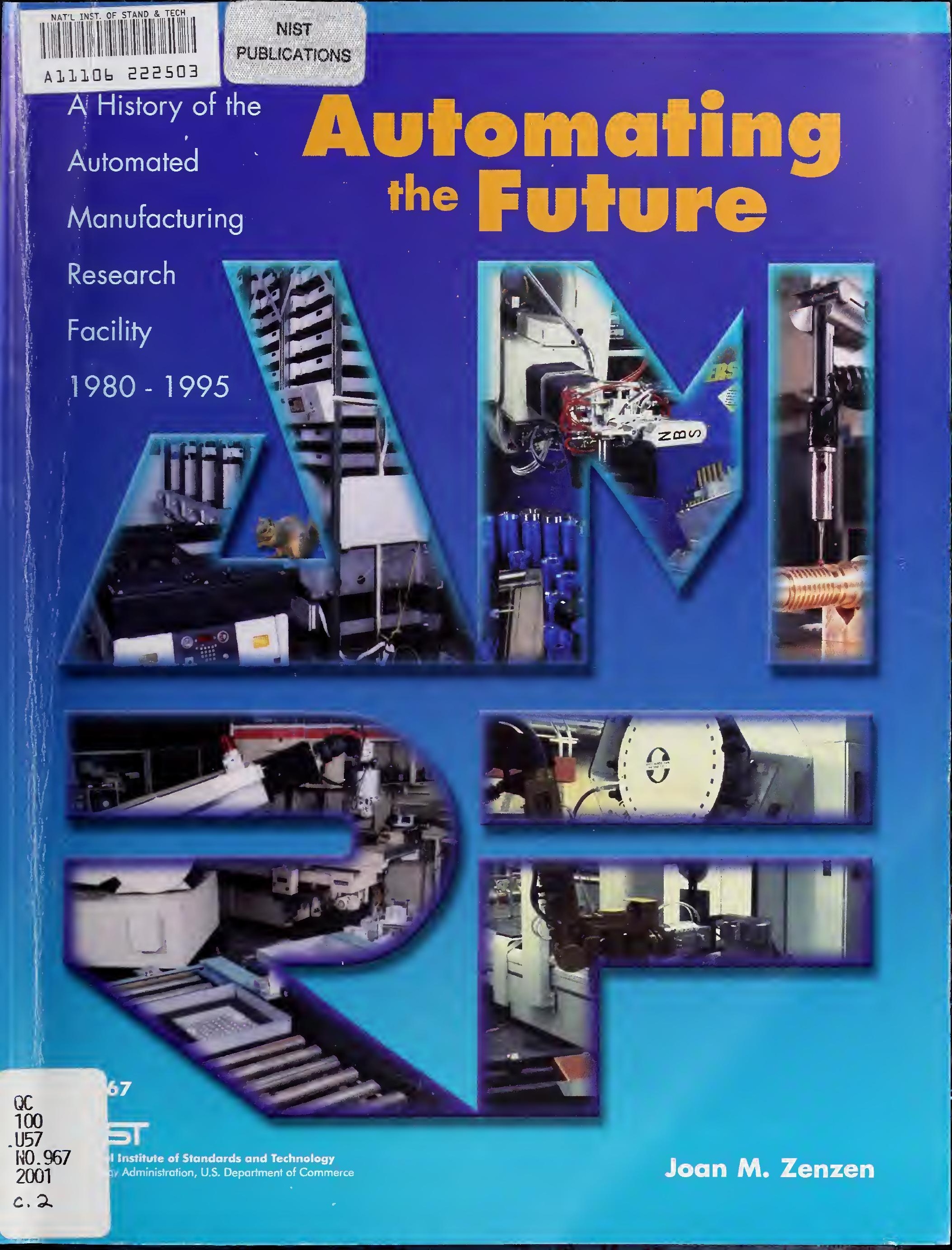




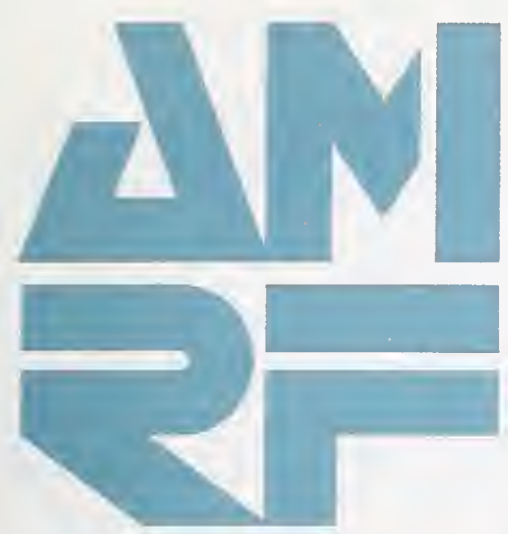

\section{AUTOMATING THE FUTURE} A HISTORY OF THE AUTOMATED MANUFACTURING RESEARCH FACILITY

\section{$1980=1995$}

\section{NIST Special Publication 967}

Joan M. Zenzen

Manufacturing Engineering Laboratory

National Institute of Standards and Technology

Gaithersburg, Maryland 20899-8200

\section{March 2001}

\section{U.S. DEPARTMENT OF COMMERCE}

Donald L. Evans, Secretary

\section{Technology Administration}

Karen H. Brown, Acting Under Secretary for Technology

National Institute of Standards and Technology

Karen H. Brown, Acting Director

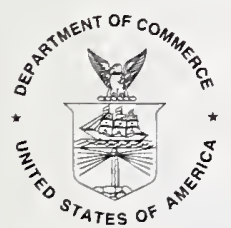




\section{Disclaimer Statement}

Commercial equipment and materials are identified in order to specify adequately certain procedures and/or research. In no case does such identification imply recommendation or endorsement by the NIST, nor does it imply that the materials or equipment identified are necessarily the best available for the purpose.

National Institute of Standards and Technology Special Publication 967

Natl. Inst. Stand. Technol. Spec. Publ. 967, 104 pages (March 2001) CODEN: NSPUE2

\section{U.S. GOVERNMENT PRINTING OFFICE - WASHINGTON: 2001}

For sale by the Superintendent of Documents, U.S. Government Printing Office Internet: bookstore.gpo.gov - Phone: (202) 512-1800 — Fax: (202) 512-2250

Mail: Stop SSOP, Washington, DC 20402-0001 


\section{CONTENTS}

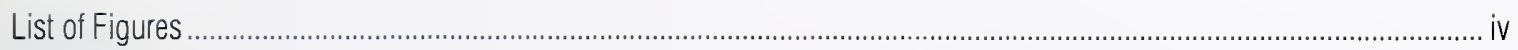

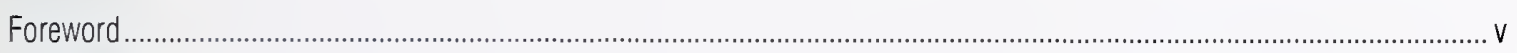

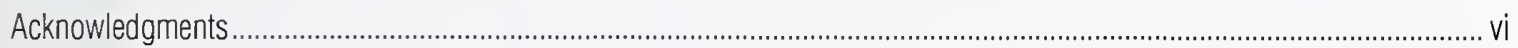

\section{Chapters}

1 Measuring for Manufacturing .............................................................................................................................. 1

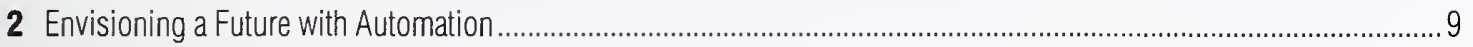

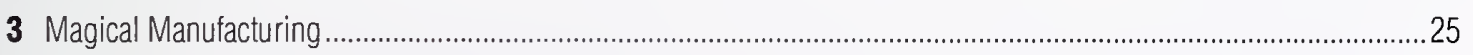

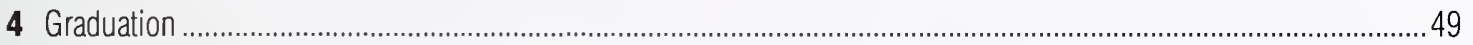

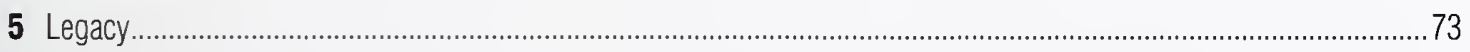

\section{Appendixes}

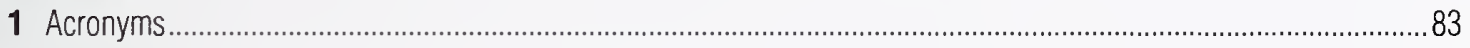

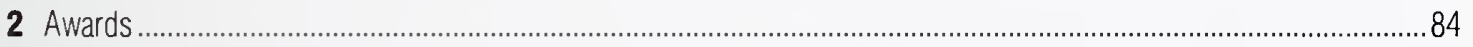

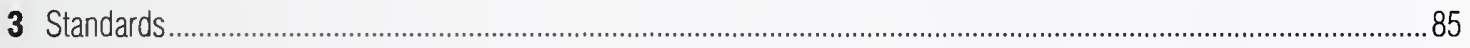

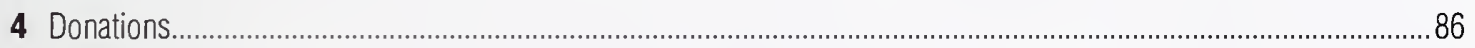

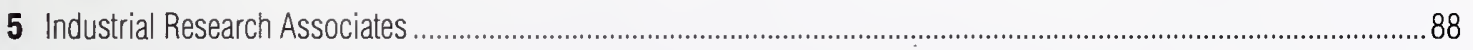

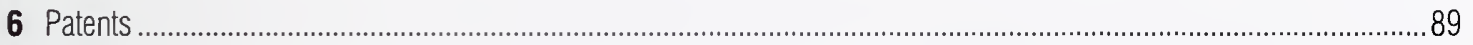

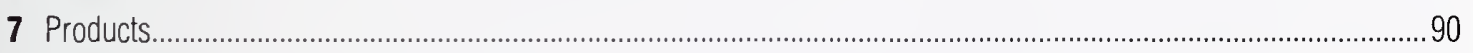

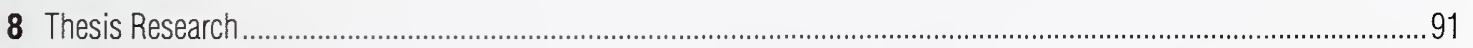

9 Academic Connections ........................................................................................................................ 92

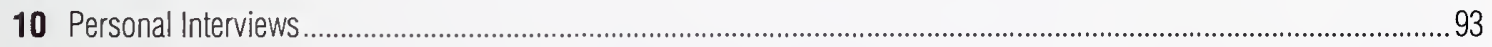

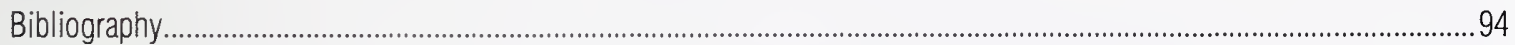

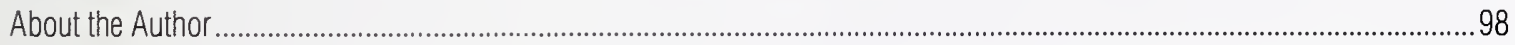




\section{FIGURES}

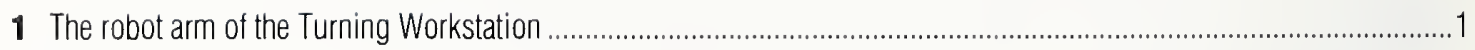

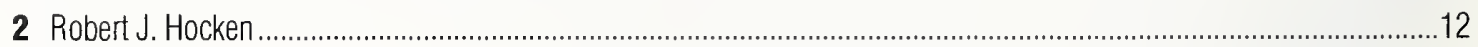

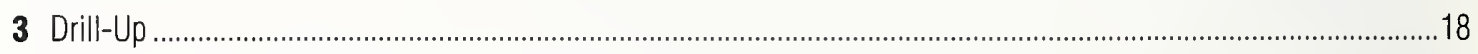

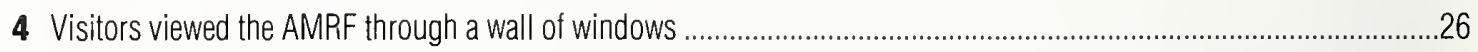

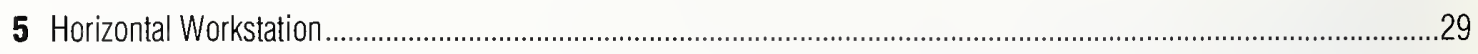

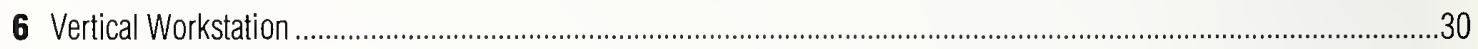

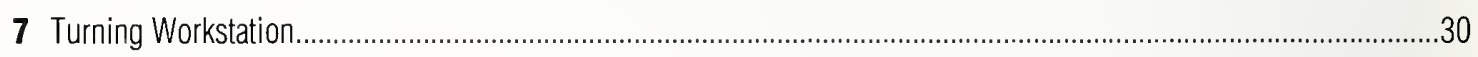

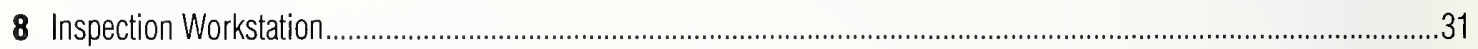

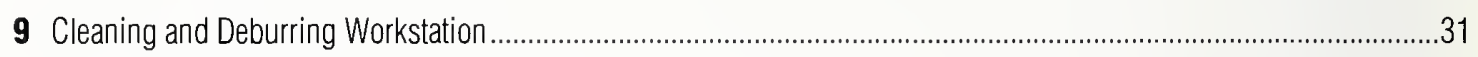

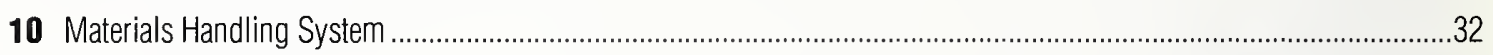

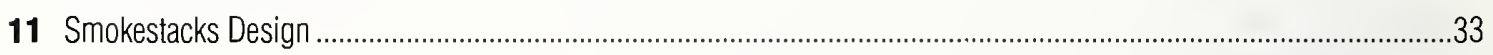

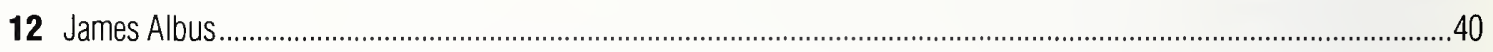

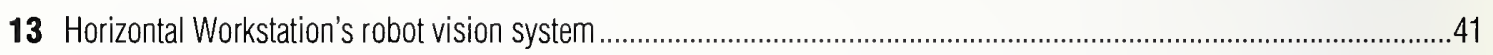

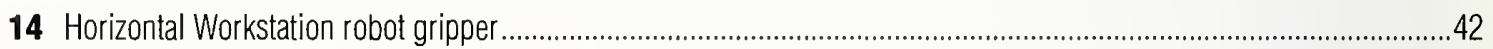

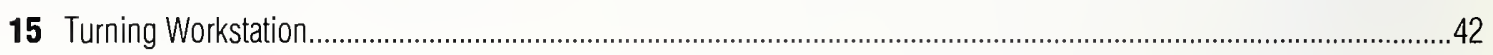

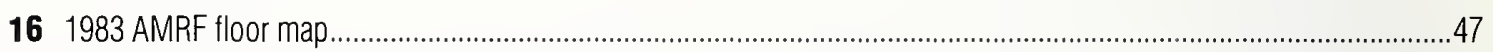

17 Demonstration of Vertical Workstation's automated process planning system.........................................................53

18 Cleaning and Deburring Workstation................................................................................................................5

19 The Advanced Deburring and Chamfering System (ADACS) ............................................................................54

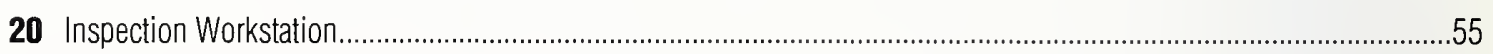

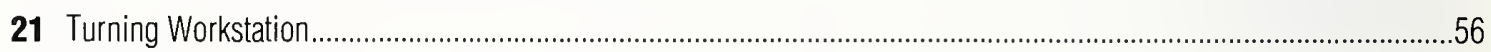

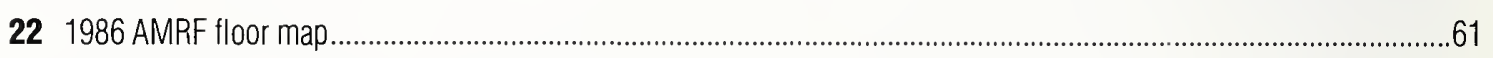

23 Mare Island Flexible Manufacturing Workstation....................................................................................................63

24 Portsmouth Naval Shipyard Level I Fastener Workstation ............................................................................................65

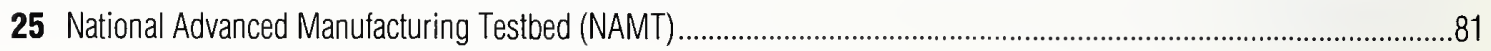




\section{FOREWORD}

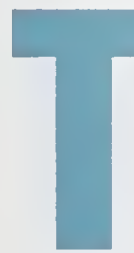

HE TECHNICAL STORY of the National Institute of Standards and Technology's (NIST's) Automated Manufacturing Research Facility (AMRF) is, in fact, the story of the integration of robots, computers, and machine tools into "the free world's largest and most advanced public research facility for the study of automated manufacturing," according to the December 1986 issue of American Machinist magazine. While the technical aspects that led up to and were the AMRF have been covered in depth in documents and conference presentations, little has been written about the researchers who actually conceived the idea for the AMRF and made it a reality, and how they did that.

As NIST prepared to celebrate its centennial in 2001, each laboratory was asked to make a contribution to the celebration. Richard H. F. Jackson, Director of the Manufacturing Engineering Laboratory (MEL) at the time, had already identified the void in the historical documentation of the AMRF and realized such a history would be the perfect item for MEL to contribute to the centennial. He had the foresight to contract with an established historian and writer to produce that history. This document, the result of that effort, is an outstanding contribution to the NIST Centennial Celebration and more than fills the void that Jackson identified. My thanks to Ric for his idea and to the author for making it a reality.

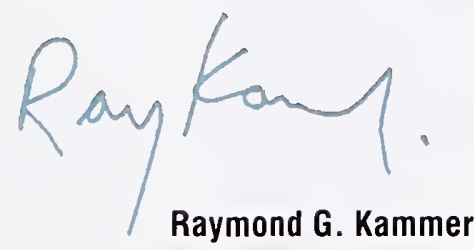

Former Director, NIST 


\section{ACKNOWLEDGMENTS}

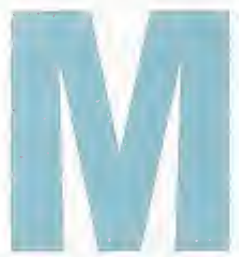

ANY FOLKS HAVE CONTRIBUTED to this history about the people who coordinated robots, computers, and machine tools into the Automated Manufacturing Research Facility (AMRF). At the National Institute of Standards and Technology (NIST), Joan Wellington in the Mariufacturing Engineering Laboratory (MEL) provided invaluable support throughout the process. She tracked down documentation, identified people for interviews, and facilitated the writing and revising stages. Harry Brooks and the other NIST librarians cheerfully and professionally fielded my many questions about technical and congressional documents. NIST historian Lisa Greenhouse pointed me to biographical files in the NIST Archives and found some photographs. Jim Schooley graciously allowed me a sneak peak of his Centennial history of NIST, Responding to National Needs. Barbara Horner sent out pages of the draft manuscript to the many interviewees and reviewers and valiantly kept track of all responses so that I could incorporate them into the revised text. Howard Bloom, first as MEL deputy director and then as MEL acting director, enthusiastically embraced this project and ensured that I had the support and resources needed to get the history done. His staff in the laboratory office, especially Rosalie Avant, Cathy Graham, Norma Purcell, and John Slotwinski, made me feel welcome and comfortable as I conducted research and completed the book. Avant also typed in some of the appendixes. Mike Schmitt helped with some administrative questions. NIST attorneys Michael Rubin and Mark Madsen made sure the oral history interviewees had proper waivers. Paul Vasallo and Sandy Kelley aided the process of initiating the contract for this book. Former MEL Director Ric Jackson recognized the value of a history of the AMRF and secured the funding for its writing. He shared his own thoughts about the significance of the facility and allowed me to sift through the documentation and make my own interpretations. He, along with Howard Bloom, James Albus, Phil Nanzetta, John Slotwinski, Charles McLean, Don Eitzen, Joan Wellington, John Simpson, and Ernest Ambler, read the entire draft manuscript and provided invaluable comments. Beamie Young created a striking book cover and shepherded the manuscript through the printing process. Bill Welsh turned the manuscript into an attractive and readable book. Special thanks goes to each of the people I interviewed, whose stories made the AMRF come alive.

Dian and Brian Belanger connected me with the people at NIST and reminded me that "stay-at-home" moms (even me with a Ph.D.) could balance home and work. My children, Sarah and Aaron, kept me focused on the important stuff, withstood my occasional absences, and always gave me hugs and kisses when I returned. My husband Stuart Weinstein encouraged me and supported me throughout this project. He read every page of the manuscript and kept our home computer from running away with my bits. I dedicate this book to my father, Nick E. Zenzen, and my brother, Nick J. Zenzen, both of whom taught me the beauty of machines. 


\section{Chapter One}

\section{MEASURING FOR MANUFACTURING}

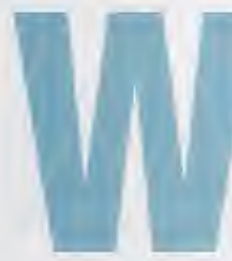

ATCHING A ROBOT AND MACHINE TOOL manufacture a widget is like watching a graceful dance. First, you hear the steady rhythm of a person typing a command into the computer terminal. Bits of information stream through silicon chips and are routed through a maze of networks, directing the performance as a part order is entered into the system. Then, you hear the motorized humming of a robot cart, rear red lights flashing alternately to the same staccato beat of the typing. Once the cart reaches the workstation, the robot, stout and squat at its base but long and extended of arm, grips the desired metal blank and sweeps it into the air in controlled, precisely directed movements. The gripper head twirls almost 360 degrees while the blank sits squarely in its hold, edges shining as they flash in and away from the light. Stop, the robot arm adjusts its position, stop, the robot arm turns again in a smaller space, and stop, the robot arm brings the blank into position for acceptance by the machine tool. The hydraulic cylinders compress and extend with each movement, sounding like each colorful balloon being blown up and tied for a festive occasion. With the blank ready for cutting, coolant rushes in and the cutter whirls and slices metal down to the desired shape. The shrill high-pitched sound of metal cutting metal is softened by the soothing liquid, washing away cuttings and cooling the pieces. With finished widget in hand, the robot arm again sweeps into its carefully orchestrated dance to transfer its product back to the robot cart (Fig. 1). Off to another partner, the cleaning and deburring station, where the widget is buffed and shined by so many whirring brushes. Finally, at its last stop, the inspection station, a calibrated glass sensor rod briefly touches and steps away, touches and steps away from the shiny metal widget. The dance is done, the widget waits for its next partner, and the robot and machine tool commence their next routine.

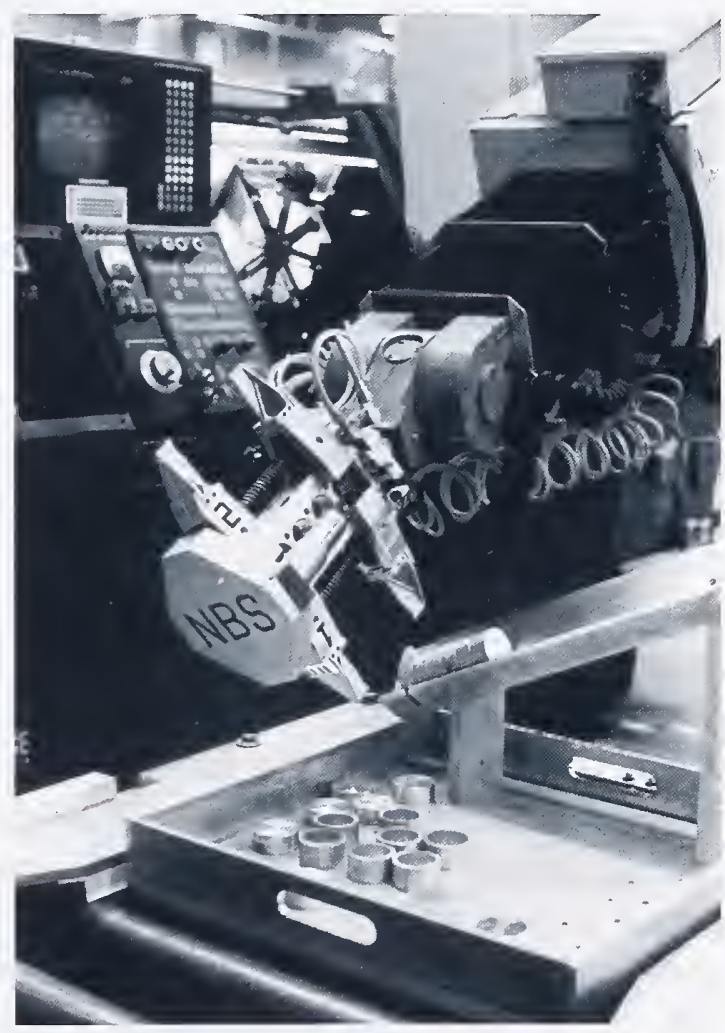

Figure 1. The robot arm of the Turning Workstation (TWS) swings into action to pick up the finished product from the turning center machine tool. (Photo collection, AMRF Files, NIST)

What was ultimately magical about the Automated Manufacturing Research Facility at the National Institute of Standards and Technology, the former National Bureau of Standards, was the elegant coordination of computers, robots, and machine tools to produce small batches of designed parts. This dance was a visible performance of the many achievements contributed by a host of scientists, engineers, technicians, managers, and theorists. Along with the underlying computer code, database systems, and control mechanisms, the AMRF served 
as the dress rehearsal, the point from which manufacturers could take the seed ideas and direct their own dances in their own real factories. This history examines the birth of the vision in the late 1970s within the NBS's Center for Mechanical Engineering and Process Technology and follows its course from realization in the Center for Manufacturing Engineering and then the Manufacturing Engineering Laboratory of NBS/NIST to its dismantlement in 1995. The many people who contributed to its success faced an assortment of challenges, and their stories will frame and guide this study. Robots dancing and machine tools whirling in artful coordination kept members of American industry, the federal government, and the larger public mesmerized and hooked on the idea of an actual automated manufacturing facility.

TEPPING BACK FOR A MINUTE, having an automated manufacturing facility developed by researchers at the venerable National Bureau of Standards appears tertiary to the agency's primary goal of providing standards of measurement for industry, commerce, government, and the public. How does this dance of computers, robots, and machine tools fit within the larger mission? It helps to look at the dynamic relationship between standards and manufacturing in the United States over time. By the beginning of the twentieth century, there were several changes in the landscape of American manufacturing. First, the improvement of life through technological advancements required the partnership of science and industry. The life-changing inventions of Thomas Edison, for example, relied upon the scientific contributions of a cadre of mathematicians, physicists, and chemists to make such things as an incandescent light bulb possible and practical. These scientists, in turn, needed precision instruments, tools, and measurement standards to support their work. Second, US manufacturing exploded, thanks to a combination of factors, including more efficient steam power to drive industrial machines, mineral exploitation to supply the raw materials, expanded transportation networks to move goods, and changed business practices using mass marketing techniques to capture a large potential population of consumers. Third, the emerging world-power status of the country as a result of the Spanish-American War gave manufacturers the opportunity to sell their increased number of goods overseas. But, this enviable situation also required that these goods demonstrate acceptable levels of quality and performance if they were to compete successfully.

Germany's experience made clear the importance of standards in supporting an expansion into world markets. Within a decade of the establishment of its Physikalisch-Technische Reichsanstalt, Germany had achieved world leadership in the manufacture of dye products, porcelain, artificial indigo, optical glass, and scientific and precision instruments. With 13,600 people employed in 760 firms, the instrument and optical glass companies alone had tripled their product exports and made no secret of their debt to the Reichsanstalt and its measurement standards for this growth. If the United States and its manufacturing companies wanted to achieve similar success, they needed to support efforts to establish an agency for standards at home. This realization became reality when on March 3, 1901, President William McKinley signed into law the act creating the National Bureau of Standards, to become effective on July 1 of that same year.'

Within the first twenty years of its existence, the Bureau established an international reputation for its developments in standards, measurement, and testing. And, with the onset of World War I, NBS further proved its utility to industry by contributing to the technological advancement of almost every aspect of wartime production. Standards in measurement brought more opportunities for innovation in manufacturing. And with those innovations came an increased need for measurement standards. One critical example was in the area of

Rexmond C. Cochrane, Measures for Progress: A History of the National Bureau of Standards (Washington, DC: US Department of Commerce, 1966; reprint, Arno Press, Inc, 1976), 14-15, 39, 47, 509. 
artillery supplies, whose manufacture reached a scale during the war that had never before been achieved for any machined product. With almost 8,000 plants around the country producing interchangeable parts and components, the need for accuracy in the gages and master gages on which they were based was paramount. The Bureau tested and calibrated gages, using precision gage blocks first designed in 1904 by Swedish engineer Carl Edvard Johannson. When these crucial blocks became unavailable during the war, NBS pursued manufacture of a satisfactory replacement set invented by William E. Hoke. By combining various sizes of these precision gage blocks, engineers could reliably make any desired dimension and ensure proper fit within the larger product. NBS Director Dr. Samuel Wesley Stratton voiced a strengthened commitment to manufacturers in his address for the 1918-1919 annual report, stating that the Bureau would be "fundamentally concerned, either directly or indirectly, with the improvement of methods of production or the quality of the output" ${ }^{2}$ of industry. His intent was to foster the same type of close relationship between the Bureau of Standards and technological interests as the Department of Agriculture had with agricultural interests. ${ }^{3}$

HERE WERE MANY MORE OPPORTUNITIES to help industry during World War II. Bureau scientists provided an endless stream of measurements on the thermodynamic properties of artificial rubber. This data was vital to American manufacturers trying to find a suitable synthetic substitute for this important wartime product whose natural supplies were now controlled by the Japanese. Gage block work continued at heightened levels, with the Bureau testing and ensuring that manufacturers used accurate measuring devices. A huge effort in Brazil to increase mining operations of critical quartz crystal, the key element for crucial radio transmission and frequency, left NBS with the necessary job of testing up to 75,000 pounds of raw crystal per month and certifying its quality. A whole range of standard samples in steel, iron, alloys, ores, ceramics, chemicals, hydrocarbons, oils, and paint pigments aided industry in ensuring acceptable wartime products. And, for the secret atomic bomb project, Bureau scientists determined methods for producing highly purified graphite (for the reactors) and uranium (for the bombs). ${ }^{4}$

For industry in the postwar period, the Bureau continued to provide gage block and other services, enhanced by using statistical quality control. This method determines the minimum number of measurements needed to ensure that on a large number of identical parts only a small known percentage would on average lie outside the given tolerance. Productivity increased markedly with this adaptation, but more importantly for the idea of the AMRF, statistical quality control also allowed measurement to aid the production process, determining trends in that process and even recommending actions to prevent drift into excessive nonconformity. The AMRF would later use the idea of combining measurement with production to produce parts within tight tolerance ranges. Statistical quality control in the 1940s and 1950s allowed NBS scientists to compare test objects to artifact standards with electronic instruments and provide for the first time, scientifically-based uncertainty statements for error. With this improved measuring capability, American industry could further explore new possibilities.

One area emerged in the development of computers. By 1946, two professors at the University of Pennsylvania had built the Electronic Numerical Integrator and Computer (ENIAC). Stored program machines

\footnotetext{
Samuel Wesley Stratton, as quoted in Cochrane, Measures for Progress, 219

Cochrane, Measures for Progress, 199-201; John A. Simpson, "Mechanical Measurement and Manufacturing," in Richard H. F. Jackson, ed, Manufacturing and Automation Systems: Techniques and Technologies: Three Pillars of Manufacturing Technology, vol. 45 of Control and Dynamic Systems: Advances in Theory and Applications, edited by C. T. Leondes (San Diego, CA: Academic Press, Inc., 1992), 19.

Cochrane, Measures for Progress, 374-5, 377-79, 423-24.

Simpson, "Mechanical Measurement," 20-21; Cochrane, Measures for Progress, 449-53. Gage block work in the 1950s also gained higher tolerances by producing highly stable steel blocks and using electro-mechanical comparators to measure length. See Elio Passaglia with Karma A. Beal, $A$ Unique Institution: The National Bureau of Standards 1950-1969 (Washington, DC: Government Printing 0ffice, 1999), 345-48.
} 
were emerging internationally at the University of Cambridge and the University of Manchester. The United States government recognized the promise of such machines, but demand outstripped the initial capability to build them. The National Bureau of Standards had the knowledge to provide at least a temporary solution until independent manufacturers could establish themselves. From its wartime research, the Bureau had gained expertise in electronics, printed circuits, and electron tubes. After the war, newly appointed NBS director Edward U. Condon, a theoretical physicist with an obvious affinity for mathematics, established the National Applied Mathematics Laboratories to address the nation's need for computing and its supporting mathematical computations. In the fall of 1948, the Electronics Division and the Machine Development Laboratory began building the world's first all solid-state electronic computer, known as the National Bureau of Standards' Eastern Automatic Computer (SEAC). At the time of its June 20, 1950, dedication, SEAC was the only stored program machine in the country and the fastest such machine in the world. Until its retirement in April 1964, SEAC completed classified computations for the military and the Atomic Energy Commission. It also assisted such agencies as Social Security and Census with statistical sorting and tabulating analysis and the Bureau itself with calculations on electronic circuit designs and optical lenses. A companion computer at the Bureau's Institute for Numerical Analysis at the University of California Los Angeles, called the NBS's Western Automatic Computer (SWAC), handled specific problems encountered by the aircraft industry while also tackling engineering, physics, and mathematical work required by federal agencies on the West coast.

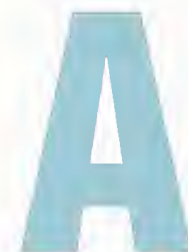

LONGSIDE DEVELOPMENTS IN PROGRAMMABLE MACHINES came the idea of programmable machine tools. Machine tools had undergone their own transformation over the past two hundred years. British inventors in the eighteenth and early nineteenth centuries had developed machine tools to manufacture interchangeable parts for the steam engine, which fueled the first industrial revolution. These contributions included the first metal lathe, boring machines for producing properly fitting cylinders for steam engines, and engine lathes for making accurate screw threads. By the nineteenth century, Americans contributed their own designs to the steady improvement in machine tool capabilities, further advancing the industrial revolution and ushering in the capability of mass production of goods. Eli Whitney, after inventing his cotton gin, designed in 1818 the first milling machine to manufacture firearms. American Joseph R. Brown, of the Brown \& Sharpe machine tool company, built in 1862 the first universal milling machine to cut helical flutes in twist drills. One of the key US contributions to the development of machine tools came between 1840 and 1850 with the invention of the turret lathe. This machine could make a complex series of cuts, such as for screws, automatically with great speed and accuracy. Machine tools capable of automatic production emerged for gear cutting (about 1860 by Gage, Warner \& Whitney of New Hampshire). Multi-spindle lathes (in 1895 by Americans Reinholdt Hakewessel and E. C. Henn) and multi-spindle milling machines (in 1898 by James Gregory of Connecticut) also appeared.

These "automatic" machine tools actually used mechanical handwheels and dials to control the cutting processes. A forerunner to the idea of automation through programming is found as early as 1801, when the French inventor Joseph-Marie Jacquard devised an automatic loom capable of producing complex patterns in textiles. The Jacquard loom used steel cards punched with holes to determine the different patterns. These cards are the ancestors for the paper cards and tapes first used to control modern computers. Not until after World War

Cochrane, Measures for Progress, 451-62; Passaglia with Beal, Unique Institution, 41-44.

William Steeds, A History of Macbine Tools 1700-1910 (London: Oxford University Press, 1969), 56, 102, 107, 123, 130, 141: "Machine tool, history" entry in Encyclopedia section of Britannica.com website; Edward E. Kirkham, "Genesis of Numerical Control," in Frank W. Wilson, ed., Numerical Control in Manufacturing (New York: McGraw-Hill Book Company, 1963), 1-3. 
II did the idea of programmable machine tools using paper cards become a reality. By this time, machine tool builders had developed sophisticated automated, but not programmable, machine tools that expanded the capabilities of mass production and also met the heavy demands for goods during World War II. Stand-alone multiple-stage die machines automatically stamped and formed metals for a wide number of applications. Precision special purpose metal cutting machines also existed, often linked with automatic materials handling equipment to form production lines in automobile manufacturing. Metal-cutting machines used template control to build parts, especially for the aircraft industry. Yet, the aircraft industry, which had to deal with increasingly complex parts requiring high levels of precision, eagerly looked for additional innovations to reduce machining costs and shorten manufacturing times.

Numerical control offered an alternative. John T. Parsons, vice president of the Parsons Corporation, Aircraft Division, in Traverse City, MI, sparked this development work when he called Professor George S. Brown at the Massachusetts Institute of Technology (MIT) in the spring of 1949, asking about the possibility of devising a small horsepower machine tool driven by intermittent data. Parsons had been experimenting with a discreteposition machining method to produce a template for an airfoil shape. His template work convinced him of the possibility that punch cards could hold this machining information and send pulse-type signals to drive power devices controlling the machine tool. Representatives from the Air Force at Wright-Patterson Air Force Base encouraged Parsons in his efforts, awarding him a contract. Parsons then turned to MIT, which had newly developed expertise in tying pulse-type data with computers. Discussions quickly led to a contract in July 1949 between the Parsons Corporation and MIT for an engineering study and development of a machine tool controlled by a computing machine. The Air Force was indirectly involved through its original contract with the Parsons Corporation. By April 1951, the Air Force had contracted directly with MIT to continue its research on an NC machine tool. In March 1952, MIT had the experimental machine tool system running and began gaining experience in operating the machine and gathering data about its accuracy and reliability. In September 1952, MIT publicly demonstrated its three-axis digitally controlled milling machine to 242 representatives from 130 industrial organizations and government agencies. MIT could report during this demonstration that over the course of 4,000 hours of operation, the machine had had an impressive total downtime of two percent. ${ }^{9}$

HIS MACHINE USHERED IN THE AGE of NC machine tools, although only the aircraft industry first embraced this development. Other industries failed to recognize the value of $\mathrm{NC}$ machine tools until after they had been proven on aircraft production floors. But, advancements continued in electronics, improving the original paper tape NC machine tools to the point that paper tape was eliminated (these machine tools became known as Computer Numerical Control or CNC tools), and finally putting a group of machines together under the control of a central computer (known as Direct Numerical Control or DNC machine tools). With these advancements and their utility proven by the $1960 \mathrm{~s}$ in the aircraft industry, other manufacturing industries began to embrace the technology. ${ }^{10}$

With computer-driven machine tools came computer-driven measuring devices, known as Coordinate Measuring Machines. CMMs, with the help of a skilled operator, could make accurate, three-dimensional measurements of many different types of objects. Again, measurement and manufacturing evolved to create new possibilities and further changes in both worlds. But, in the case of computers entering the relationship, the

\footnotetext{
Kirkham, "Genesis of NC," 4; "Automation" entry in The New Encyclopaedia Britannica, Macropaedia, vol. 14 (Chicago: Encyclopaedia Britannica, Inc., 1995), 549 .

J. Francis Reintjes, Numerical Control: Making a New Technology (New York: Oxford University Press, 1991), 16-25, 38-47.

${ }^{10}$ Ibid, 154-55, 176.
} 
National Bureau of Standards faced a new challenge. Ironically, the home of the country's first programmable machine, SEAC, the Bureau's metrology division remained committed to gears and master blocks, artifact standards that had existed since the 1901 establishment. Nowhere in the dimensional metrology program did you see evidence of computers. To bring the division up to the times and as part of an overall effort to modernize metrology throughout the Bureau, Ernest Ambler, Director of the Institute of Basic Standards (and later NBS director), combined the metrology division with the Atomic Physics Program, which had been the Bureau's research arm for optics, electronics, and lasers. Putting physicist John Simpson in place as deputy chief for metrology, Ambler called for the automation of the calibration process, to meet the new demands of manufacturing. With a budget initiative from Congress, NBS purchased a coordinate measuring machine and a mini-computer (the size of a house refrigerator) and began its investigations. ${ }^{11}$

Ambler and his newly-invigorated metrology group never turned back from the promise of automation. When gear manufacturers called for the expansion of the gear calibration program to meet increasingly tighter tolerance limits, Ambler said no. As Simpson later wrote, "In an act of considerable political courage, and even more optimism," ${ }^{12}$ Ambler shut down the entire gear laboratory and made the new measuring machine facility the source for gear calibrations. Gage and gear calibrations remained available for certain situations, but as Ambler later recalled, "it was clear that that kind of technology was reaching the end of the line."13 $T h e$ second industrial revolution, with the computer as the centerpiece, was on.

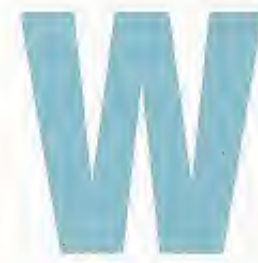

HAT DID COMPUTERS PROMISE US manufacturers and how could the National Bureau of Standards help integrate them into industry? Again, the interplay of standards and manufacturing played a key role in the answer. Measuring capabilities, thanks to the coordinate measuring machine, added greater possibilities for advancements in manufacturing. But, even CMMs had their limitations. Many part families, either because of their small size or level of complexity, were ill-suited to this type of measurement. In addition, companies began adopting, for financial reasons, shorter runs of part manufacturing to reduce inventories and the money it cost to store those inventories. Calibrations, whether automated or not, wasted valuable manufacturing and labor time because a known percentage of completed parts had to be thrown away or recycled for not meeting specifications. NBS researchers became convinced that metrology, this measuring process, had to move from the laboratory and into the manufacturing process. By measuring the machine - monitoring its parameters - manufacturers could one day produce the part right the first time. This new measuring system became known as deterministic metrology. When linked with robots and automated with computers, the simple machine tool of yesterday would potentially become an economically valuable resource for the future. Simpson later noted that "It made sense to all of us that if we were going to provide the type of research that would be useful to the American community, we would have to do the same thing," move to the production floor. And so, the idea for the AMRF arose. ${ }^{14}$

American industry in the late 1970s needed all the help it could get. The world was becoming a global marketplace and competition was stiff. Once unknown companies from places like Japan and Germany became industry leaders by adopting different, less costly managerial and technological innovations, and making

\footnotetext{
'Simpson, "Mechanical Measurement," 21-22. "The AM Award: Dr. John Simpson," American Machinist and Automated Manufacturing (December 1986): 61-62.

Simpson, "Mechanical Measurement," 22.

${ }^{13}$ Ernest Ambler, interview by Karma Beal, July 27, 1988, transcript, 11, NIST Archives.

${ }^{14}$ J. A. Simpson, R. J. Hocken, J. S. Albus, "The Automated Manufacturing Research Facility of the National Bureau of Standards," Journal of Manufacturing Systems 1 (1982): 19. Simpson quote from John Simpson, interview by the author, February 25, 2000, audiotape, NIST.
} 
superior products. US manufacturers, after decades of being the unquestioned providers of goods in several industries, failed to change, with disastrous results. In 1971, for the first time in the twentieth century, the United States measured a negative merchandise trade balance. With only a brief rise in the 1976 period, the merchandise and manufacturing trade balances dropped rapidly, taking away the US lead in semi-conductor equipment, automobiles, and machine tools. The consumer electronics industry told an even sorrier story. In 1955, 96 percent of all radios sold in the US were made here. That number dropped by 30 percent by 1965 . By 1975, it was near zero. Attention might focus on the big manufacturers, such as the Big Three automobile companies in Detroit and how to help them. But, in reality, those companies slowly adopted computers and automated their production processes with the introduction of robots. They had the capital and the large production base of making identical parts. They certainly could use assistance, but the real problem laid in the discrete-parts manufacturing industry. Seventy-five percent of all US trade in manufactured goods was done by companies producing in small lots or batches rather than in mass quantities. These companies in the late 1970s and early 1980s hardly had a computer on their premises, let alone integrated into the production process. Yet, they could have benefited significantly. Computers and automation promised flexibility. As the vision went, a company could produce one widget, reprogram the computer, and right away make a completely different widget. Each one would be within tight tolerances and without wasting time or materials. NBS researchers focused on these customers when designing the AMRF. ${ }^{15}$

This book examines the many challenges Bureau scientists faced in realizing their dream of a fully automated manufacturing facility. My central argument, developed in five chapters, is that government has a responsibility to provide the research support needed by industry now and in the future to encourage growth and stability. Industry alone does not have the financial resources to engage in this work. And, cross-fertilization of ideas, a hallmark of the AMRF, is not possible if research is conducted solely in industry labs. This chapter laid out why the primary research institute of the US federal government would venture into the world of automated manufacturing. The next chapter will provide the nuts and bolts of how the AMRF went from an idea talked about among scientists in offices and at kitchen tables to an actual place carved out of the NBS Instrument Shops. The challenges of getting upper Bureau management to support the project and the effort to win financial backing from Congress and the Navy will be detailed. Chapter Three, in some ways the heart of the story, recounts the many challenges faced and overcome to demonstrate the feasibility of an automated factory. Major technological and management innovations will be spotlighted in terms of how they contributed to the working facility. Scientists, engineers, managers, and technicians all gained a strong sense of camaraderie as they focused on the common mission of demonstrating the full facility, and their stories, gleaned from oral history interviews, will be recounted. The collaborative nature of government employees, industry representatives, and academic researchers from universities will be explored. Standards work, which made it possible for computers, robots, and machine tools to talk with each other and automate production, will be explained. Industry involvement and Navy sponsorship kept the AMRF alive. Regular demonstrations, articles, and other public relations efforts ensured visibility. Chapter Four relates how the AMRF shifted focus after full demonstration of the facility in 1986. From a single-mission enterprise to a laboratory for exploring individual research projects, the AMRF made a range of contributions to its customers. Finally, Chapter Five looks at the reasons for closing the AMRF in 1995 and its legacy.

\footnotetext{
${ }^{15}$ Craig Giffi, Aleda V. Roth, Gregory U. Seal, Competing in World-class Manufacturing: America's $21^{3}$ Century Cballenge (Homewood, 1L: Business One Irwin, 1990), 1-8. Thomas G. Gunn, Manufacturing for Competitive Advantage: Becoming a World Class Manufacturer (Cambridge, MA: Ballinger Publishing Company, 1987), 1-14. NBS Annual Reports, 1978, 52; 1981/1982, 4, N1ST Library.
} 
HE STORY OF THE AMRF is an important one. A broad coalition of government, industry, and university researchers concentrated on a single problem of national significance. Crossing of boundaries became the norm, a new idea especially for the lone scientist model often used in the past at the National Bureau of Standards. People with all kinds of training, in physics, mathematics, electrical engineering, artificial intelligence, computer science, databases, and manufacturing came together as a group to solve a pressing problem. The Bureau would never be the same again. Readers interested in the functioning and goals of government will gain an understanding of how such a large and complex project functioned and succeeded. Industry representatives will gain an appreciation of the benefits of sharing expertise and knowledge. Historians of technology will learn about technological advances of the recent past and how they have shaped industry and the government. Scientists will see the impact of individual research on a whole area of the American economy. Managers will obtain clues on some of the practices that helped move the project forward. The general reader will get a good story about the commitment and innovative work of a group of dedicated individuals. One hopes that this story will inspire future directions in collaborative research. Let the dance begin. 


\section{Chapter Two}

\section{ENVISIONING A FUTURE WITH AUTOMATION}

HE DANCE now known as the Automated Manufacturing Research Facility was at first a slow one with many partners, many visions contributing to its evolving form. Concerns about foreign competition in US markets set the stage for the dance. Promising technical advances in computers and robots gave dancers the framework for designing their response. A range of players, often working solo or in small groups, experimented with different moves. Footwork emerged and then, suddenly, an entire choreography crystallized.

A 1976 General Accounting Office Report to Congress titled Manufacturing Technology - A Changing Challenge to Improved Technology set the dark stage. Over the past thirty years, the report lamented, other industrialized nations had consistently higher rates of improved industrial productivity than those of the United States. Only the first decade of this increase could be attributed to rebuilding after World War II. As late as the period 1960-1973, US productivity increased at an annual rate of only 3.3 percent while West Germany had an average 5.8 percent increase and Japan a whopping 10.7 average annual increase. These numbers gave pause to the notion that the United States was economically healthy, able to withstand foreign competition and maintain its lead in many manufacturing and production fields.

Business executives, industry watchers, manufacturers, and professional societies were all too aware of the situation. One newspaper reporter described America's productivity rate as "creeping closer and closer to a dead stop." Even President Carter's special assistant for inflation and trade policy called productivity a "terrible problem for this nation . . a difficult and debilitating problem." Yet, the United States government failed to show committed leadership in confronting its productivity slump. In 1971, President Richard M. Nixon established the National Commission for Productivity and Work Quality to provide a national productivity focus. A name change in $1975 \mathrm{kept}$ this same focus, but neither organization directed its efforts specifically to manufacturing technology. By 1978, President Carter and the Congress quietly let the center die. ${ }^{4}$ The Carter administration explained that "The best thing we can do for productivity is to create a healthy climate for private investment. . . . productivity is basically the responsibility of the private sector." Another early 1970s National Science Foundation program, called Research Applied to National Needs (RANN), supported efforts in energy, the environment, and urban life. Some engineering and manufacturing advancements came out of RANN, but again

\footnotetext{
United States General Accounting Office, Report to the Congress by the Comptroller General of the United States: Manufacturing Technology - A Changing Challenge to Improved Technology, LCD-75-436 (Washington, DC: GP0, 1976), 55, File I-5, John Simpson Files, Manufacturing Engineering Laboratory (MEL), NIST. The GAO defines productivity in the manufacturing environment as the relationship between output (products manufactured) and input (resources consumed in the manufacturing process). For comparative purposes, output per person-hour of input is commonly used. Quote by Bradley Graham, "US Productivity: Golden Days 0ver," Washington Post (September 10, 1978), F5, File B-1, Simpson Files, MEL, NIST. Robert Strauss, quoted in Bradley Graham, "Productivity Problems Outlined," Washington Post (October 4, 1978), C-1, Simpson Files, MEL, NIST. GA0, Manufacturing Tecbnology, 76; Graham, "US Productivity: Golden Days Over," F5.

Carter administration official (unidentified) quoted by Graham, "US Productivity: Golden Days Over," F5.
} 
it died by fall 1977 with no replacement. ${ }^{6}$ The newly launched Air Force-Department of Defense program called Integrated Computer-Aided Manufacturing (ICAM) had its budget reduced in the program's first full year of operation, 1978. The Society of Manufacturing Engineers raised its collective hands in despair. In ominous language, the society predicted "the rapid decay of American industry and the degeneration of America itself into a small and unimportant industrial backwater" if no action was taken.

Studies from the early 1970 s had identified where productivity could get a big boost. Manufacturing, which contributes approximately 30 percent of the gross national product of modern industrialized nations, was not as efficient as generally believed. In the area of batch-type or discrete parts metalworking, which accounts for about 40 percent of total manufacturing employment and produces 75 percent of metal parts, this assumption was glaringly wrong. Charles F. Carter, Technical Director for Cincinnati Milacron, the leading US machine tool manufacturer, followed the creation of such work pieces in manufacturing plants and discovered that only about 1.5 percent of the overall manufacturing time for a piece was spent as productive time removing metal. Parts spent the rest of their time waiting for machine tools to warm up, waiting to be transferred to another machine tool or inspection station, and waiting for other unfinished pieces to be completed for product assembly. Machine shops thus had high inventories of in-process parts, taking up space and money without adding to productivity. Carter's study of machine tool usage also indicated problem areas for productivity. The average machine tool in a batch-type shop, which produced parts in small-lot sizes, was used to cut metal only about 15 percent of the time. Fifty percent of the time, machine tools were waiting for parts to cut, leaving firms with the high cost of maintaining this expensive equipment without gaining productive - profitable - benefits. ${ }^{9}$

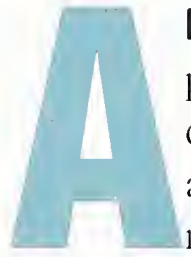

LL EYES TURNED TO AUTOMATION and the automatic factory as the answer to boosting productivity. The Society of Manufacturing Engineers prophetically pronounced that "the continuing and rapidly accelerating evolution of industry has now brought us to the gates of the automatic factory." And none too soon. One company executive encapsulated the thoughts of many by stating that "the Automatic Factory is probably the only means available for raising or at least maintaining the American standard of living." What is automation and why was it considered to be so important? An engineering manager at Ford Motor Company in 1946 coined the term automation to describe the increased use of automatic devices in mechanized production. Automation has come to mean the technological process of using programmed commands combined with automatic feedback control to ensure proper execution of instructions. Robotics is a specialized branch of automation, in which the automated machine possesses certain human-like characteristics, such as an arm with multiple degrees of freedom. The idea of the automated factory ranged along a continuum, from a company having a few robots working on a production line with mostly human workers to a total "lights-out factory" without direct human intervention. ${ }^{12}$

\footnotetext{
"For a detailed look at the RANN program, see Dian 0lson Belanger, Enabling American Imovation: Engineering and the National Science Foundation (West Lafayette, IN: Purdue University, 1998), chapters three and four.

Society of Manufacturing Engineers, The National Role and Importance of Manufacturing Engineering and Advanced Manufacturing Technology (May 1978), Enclosure 1, p. 5, File I-21, Simpson Files, MEL, NIST.

Ibid, Enclosure 1, p. 5.

Carter study, "Trends in Machine Tool Development and Application," Proceedings of the Second International Conference on Product Development and Manufacturing Technology (London: Macdonald, 1972), 125-41, referenced in M. Eugene Merchant, "Future Trends in Manufacturing-Toward the Year 2000," Annals of the CIRP vol. 25, no. 2 (1976): 473-75. M. E. Merchant, "The Coming of the Automatic Factory," Manufacturing Engineering (March 1980): 70-71, File C-5, Simpson Files, MEL, NIST.

${ }^{10} \mathrm{Ibid}$, Enclosure 1, p. 5.

S. K. Smith, Eaton Corporation, quoted by Daniel B. Dallas, "The Advent of the Automatic Factory," Manufacturing Engineering (November 1980): 73, File C-33, Simpson Files, MEL, NIST.

"Automation" entry in The New Encyclopaedia Britannica, Macropaedia, vol. 14 (Chicago: Encyclopaedia Britannica, Inc, 1995), 548.
} 
Facts and figures made clear the importance of any kind of automation to manufacturing. Carter's study of machine tools and parts showed that with computer-integrated automatic factories, the huge inventory of inprocess parts could be reduced up to 90 percent, realizing enormous gains in indirect capital and labor costs and productivity. Automation could also increase machine tool usage by 600 percent or more, thereby vastly reducing direct labor and overhead costs and promising big improvements in productivity. The theory went that as medium-sized batch-machine shops, who essentially produce all the machinery used to manufacture everything else, became more productive and significantly reduced their costs, they could pass this savings to their customers. The entire manufacturing community would see a profound impact on productivity. ${ }^{13}$

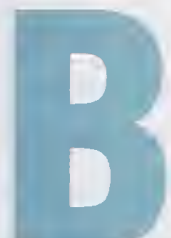

Y THE LATE 1970s, the United States and other countries had made their first forays into automation. A West Coast General Motors (GM) facility could turn a strip of steel and coiled bar into a completely finished wheel without any manual assistance. A New Jersey manufacturer of fire extinguishers took a billet of steel and shaped, heat treated, machined, assembled, tested, painted, and packaged its product without a human touching the process. In West Germany, an impressive automated system in an aircraft manufacturing line in Augsburg had large machining centers with automatic tool setting and tool changing. Automatic carts brought parts to each center. In Japan, Seiko took handmachined watch parts and used an automatic system for assembly. ${ }^{14}$ These programs existed and succeeded because they were hard wired, they could do a single job without introducing flexibility. GM needed a bunch of wheels and Seiko built lots of the same style watch, so having their processes automated made sense and could be done fairly simply, once the computer and robot technology had been established. The real trick was applying flexibility to automated machine tools so that they could make, in quick succession, a range of different parts in lot sizes as small as one.

\section{Two lines converge}

By 1978, two separate areas of research at the National Bureau of Standards converged, providing an American answer to the puzzle of flexible computer integrated manufacturing. From the stark stage of reduced American productivity and foreign competition came the beginning of a framework for the AMRF dance. One research line started in 1968 when Ernest Ambler, then Director of the Institute of Basic Standards, put atomic physicist John Simpson in charge of automating 3-dimensional metrology. This appointment began Simpson's second of three "careers" at the Bureau. He had started in 1948 as a research physicist in electron physics, building a series of electron spectrometers to obtain detailed information on the structure of atoms and molecules. One of these instruments proved an exceedingly sensitive detector of atmospheric pollutants with commercial applications. He became more and more fascinated with instruments as opposed to the results obtained from them, so Simpson welcomed the opportunity to combine his physics background with metrology, the start of his second "career." His third incarnation at NBS would be in manufacturing, as director of the center that ran the AMRF. ${ }^{15}$

Carter study, "Trends in Machine Tool Development, as referenced in Merchant, "Future Trends in Manufacturing," 473-75. Richard C. Dorf, Robotics and Automated Manufacturing (Reston, VA: Reston Publishing Company, Inc, 1983), 30; Merchant, "The Coming of the Automatic Factory," 70-71.

"Dallas, "Advent of the Automatic Factory," 68.

"The AM Award: Dr. John A. Simpson," American Machinist and Automated Manufacturing (December 1986): 61-62; Michael Baum, "Automation 'Czar' Receives Presidential Award," Commerce People (April 1986), 8; John A. Simpson, interview by Karma Beal, 1993, transcript, NIST Archives; John Simpson, interview by author, February 25, 2000, audiotape, NIST; Karl G. Kessler, Recommendation for Gold Medal Award, May 6, 1975, 2, John simpson Biographical Files, MEL, NIST. 
To automate metrology in the late 1960s, Simpson and his staff purchased a modified Moore 48, jig boring machine, which Moore Special Tool of Bridgeport, CT, had outfitted with a sensor probe to turn it into a coordinate measuring machine (CMM). Simpson's team, including Phil Stein, then added a mini-computer to control the machine, creating the first automated CMM. Yet, this device had inherent inaccuracies, and so the

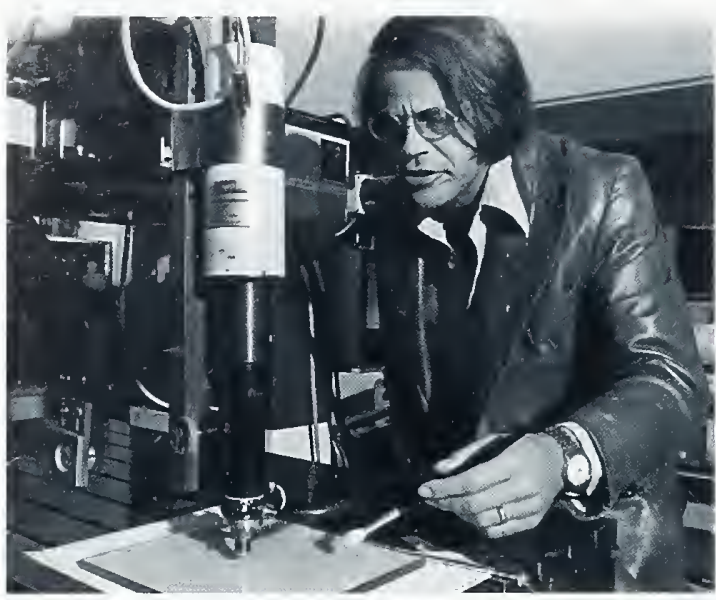

Figure 2. Robert J. Hocken (shown here) shared the NBS Applied Research Award in November 1980 with John Simpson and William Haight for their work on a selfcorrecting, three-axis coordinate measuring machine. (NBS 1978 Annual Report, 52) team, with John Lazar, added laser interferometry, to make the basic length measurements, with lasers built by Hewlett Packard and originally designed by engineer Dick Baldwin. Laser interferometry offered accuracy, versatility, and easy interfacing to digital dataprocessing equipment, the computer. Robert Hocken (Fig. 2), with William Haight and Bruce Borchardt, all of whom had recently joined Simpson's team, realized that the machine errors were repeatable and that error maps could be created without real-time measurement. In 1977, they explored this idea in expanded 3dimensional metrology laboratory facilities. They applied mathematical algorithms, traceable to elementary graduate school physics, to repeated measurements of an object in different orientations and characterized the machine's in-process gauging errors.

With the resulting error correction map, the computer automatically factored out most of the measuring machine's errors, caused from misalignment, wear and tear, and heat expansion. This self-correcting, three-axis coordinate measuring machine earned Simpson, Hocken, and Haight the NBS Applied Research Award in November 1980. Their work demonstrated that building the perfect measuring machine was unnecessary. It was only necessary to build a machine that was highly repeatable, for then one could compensate for errors through mapping and fast computing. The NBS researchers realized, though, that not every manufactured part could or should be measured by this new machine, due to the level of complexity or size of a part. Instead, they became convinced that measurement for quality control had to occur during the manufacturing process, on the machine tools themselves. ${ }^{16}$

The second line of research developed out of the Bureau's Institute for Computer Sciences and Technology and its director Ruth Davis. While working at the Defense Advanced Research Projects Agency (DARPA) in the 1960s, Davis had funded projects in the emerging field of artificial intelligence at the Massachusetts Institute of Technology, Carnegie-Mellon, and Stanford. She had never been comfortable with the initial findings of this work, which argued that a control theory for running an autonomous machine was not possible in the foreseeable future. Once at NBS, she continued to talk about the future of artificial intelligence (AI) and in 1971, attracted the intellectual curiosity of John Evans. Evans had done his high school science project on the

\footnotetext{
William P. Meade, The National Bureau of Standards' Automated Manufacturing Researcb Facility (AMRF): An Analysis of its Impact (Chapel Hill, NC: Management Collaborative Group, 1984), 19; "The AM Award: Dr. John A. Simpson," 62; Robert J. Hocken and Philip Nanzetta, "Dimensional Metrology at the National Bureau of Standards," The Physics Teacher 21:8 (November 1983): 509-1 1; US Department of Commerce, "Three Scientists Receive Applied Research Award from NBS," News release 80-21 (November 14, 1980), File Simpson, John A., NIST Archives; Simpson, "Mechanical Measurement," 23; Kessler, Recommendation for Gold Medal Award, 2; Lawrence Livermore Laboratory, Machine Tool Task Force, Robert J. Hocken, Working Group Chairman, Technology of Machine Tools, vol. 5, Machine Tool Accuracy, UCRL-52960-5 (Livermore: University of California, 1980), 26; NBS, Annual Report, Fiscal Year 1978, 53; Robert Hocken, interview by author, March 3, 2000; Thomas Charlton, interview by author, May 8, 2000, both audiotapes, NIST.
} 
perceptron, the first neural network, an early idea in AI. Now with a Ph.D. in astrophysics, he was hunting for areas at NBS to explore his interests in AI and applied technology. Davis set Evans up in a small automation technology group within her institute and provided funding. This group immediately began focusing its attention on robots and America's declining productivity rate. ${ }^{17}$ Yet, it didn't take off until 1973 when Evans hired James Albus, a decision which former director Ray Kammer proudly described as "one of the smartest things John did."18

Albus lived and breathed robots. But, robots were only a stepping stone, a laboratory for understanding the really big stuff: intelligent behavior. For his Ph.D. dissertation, he proposed a model of the cerebellum, the part of the brain that controls motor coordination, and then built a computer model of a cerebellum to control a robot. Formalized as the Cerebellum Model of Articulation Control, CMAC has proven useful in neural network control systems and served as a starting point for the control architecture of the Automated Manufacturing Research Facility. Albus had been at NASA where he designed electro-optical systems for more than 15 satellites. He then became program manager of the NASA Artificial Intelligence Program and talked up his ideas about robot control, only to deaf ears. When Evans heard the same ideas, he practically hired Albus on the spot, quickly recognizing the potential his AI ideas had on industrial robots. And, Albus understood that manufacturing offered the first large-scale testbed for robots and his ideas on intelligent behavior. Industry needed to boost productivity, and robots promised huge gains the more they were integrated. "Following the money" meant applying his ideas to industry, so Albus joined Evans in the NBS automation technology group. ${ }^{19}$

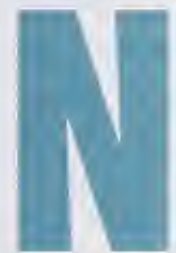

OW THE FUN STARTED. By 1974, Albus had developed a mobile robot for the US Navy to work in hazardous environments, protecting humans from potentially dangerous tasks. He had also worked with Evans and Robert Lach, the NBS Shops foreman, on marrying a crude "robot," in actuality an arm with an automatic opening vise, to an Excello machine tool. The vise would load the machine tool, taking the place of a human operator. Vision work proceeded by 1977 at the request of NASA. Albus's design used a solid state camera and flash unit to create planes of light across an object to determine its position and orientation. This work held the promise of increasing manufacturing productivity by reducing the need for human operators at machine tool stations or in the material handling system. A 1978 contract with the US Air Force under its Integrated Computer-Aided Manufacturing (ICAM) program, which helped batch-processing aerospace firms, led to work on establishing guidelines for robot selection, robot computer languages, and robot control systems. ${ }^{20}$

Underlying all of this robot work was a gem of an idea: a hierarchical control system. Building on the layered model of the cerebellum he had developed in his dissertation, Albus explored how a hierarchical structure

\footnotetext{
Davis continued to be active in attempts to stretch the work of the automation technology work beyond its sphere in the Institute for Computer Sciences and Technology, knowing that automation research required cutting across disciplinary lines. This effort achieved success with the fiscal year 1978 budget, with automation technology named as the top priority for NBS, supported by a $\$ 1$ million congressional appropriation. This money went with the automation technology group when it was enveloped into the new Center for Mechanical Engineering and Process Technology (CMEPT). See House Committee on Science and Technology, Subcommittee on Science, Research and Technology, $97^{\text {th }}$ Cong., $1^{\text {t }}$ sess., The National Bureau of Standards: A Review of Its Organization and Operations 1971-1980 (May 1981), 98, note 168; CMEPT, Long-Range Plan (November 1978), File CMEPT Long Range Plan, AVIRF Files, NIST.

Kammer quote from Ray Kammer, interview by author, June 16, 2000; John Evans, interview by author, February 18, 2000; James Albus, interview by author, February 25, 2000; John Lyons, interview by author, July 28, 2000, all audiotapes, NIST.

${ }^{19}$ Albus quoted in Albus, interview, February 25, 2000; James S. Albus, Brains, Behavior, and Robotics (Peterborough, NH: BYTE Books, 1981), 143-45, 275-76, 301; Kammer, interview, June 16, 2000; J. A. Simpson, R. J. Hocken, J. S. Albus, "The Automated Manufacturing Research Facility of the National Bureau of Standards," Journal of Manufacturing Systems 1:1 (1982): 32.

${ }^{20}$ Albus, Brains, Behavior, and Robotics, 257; Albus, interview, February 25, 2000; Anthony Barbera, interview by author, May 22, 2000, audiotape, NIST; NBS Annual Reports, Fiscal Year 1974, 19; Fiscal Year 1975, 17; Fiscal Year 1978, 52-53, all in NIST Library; Robert Lach, interview by author, July 21, 2000, audiotape, NIST. For information on robot vision, see Paul R. Cohen and Edward A. Feigenbaum, eds., The Handbook of Artificial Intelligence, vol. 3 (Los Altos, CA: William Kaufmann, Inc., 1982), chapter 13; Aibus is cited on p. 258.
} 
might answer a perplexing problem in robotics. If a simple robot interacts and reads only a few pieces of sensory information, then designers could use almost any type of control system structure for coordinating robot, computer, and other hardware. Once that robot begins to interact in a sophisticated way with a range of sensory data, though, the underlying structure becomes problematic. Single-layer control programs, as Ruth Davis had encountered in the late 1950s, become enormously complex to write and almost impossible to correct for errors. Computing power was only slowly making such complex programs even possible to run. Instead, Albus argued that the control structure should be broken down into modules or layers, like an army is broken down into different commands. The main attraction of such a hierarchical design is that it can be partitioned to limit complexity in any one module, regardless of how complex the overall system may be. In addition, using state tables, each module becomes autonomous, taking in sensory data and producing the desired output based on the conditions established in the tables. ${ }^{21}$

Anthony Barbera, who joined the group late in 1974, began testing Albus's theories on computer control systems. Barbera had first worked with Albus in the late 1960s at NASA, where Albus shared his thoughts about intelligence, neurophysiology, and robotics. Caught by the "bug," Barbera completed a Ph.D. in biophysics at Johns Hopkins University and immediately joined Albus at the Bureau of Standards. From 1975 on, Barbera and the automation technology group, which came to include Mary Lynn Fitzgerald, Gordon Vanderbrugh, Roger Nagel, and Brad Smith, experimented with control systems using the "Stanford Arm," a small test robot designed by a Stanford University student. One result of this work was the development of a way for each module of a hierarchical control system to interact with sensory and other data in real time. This Real-time Control System (RCS) used a mailbox feature, or common memory, for communication between modules. Every twenty milliseconds or so, each module queried the central mailbox and received its set of input commands. With this information, the module used its state tables to compute its output commands, which were sent back to the mailbox. In another twenty milliseconds, the process repeated. ${ }^{22}$

Such a system had the drawback of requiring modules to talk through the mailbox as opposed to talking to themselves directly. However, this arrangement made it unnecessary for the modules to share a common language; the mailbox did any translating required. In addition, the mailbox made it easy to add new computers or other hardware to the overall system, so long as each newcomer provided its "address" to the relevant modules. Operators could readily access maps of the current state of the system and stop the query process at any point. The real-time aspect of this arrangement becomes apparent by the fact that modules do not waste their time reading unnecessary mail. Each module reads only the parts of common memory defined for it and reacts accordingly. Unnecessary chatter is eliminated. The combined ideas of hierarchical control and a real-time control system would serve as the foundation for controlling the different systems in the AMRF. The idea of hierarchical control would also be accepted world-wide in automated manufacturing. ${ }^{24}$ Back to 1976 , the dimensional metrologists

\footnotetext{
Albus, Brains, Behavior, and Robotics, 261, 267-68.

Peter L. Blake, ed, Advanced Manufacturing Technology (New York: North-Holland Publishing Company, 1980), 238; Barbera, interview, May 22, 2000; Albus, interview, February 25, 2000; Albus, Brains, Behavior, and Robotics, 276-79; Simpson, "Mechanical Measurement," 27; Simpson, interview, February 25, 2000.

${ }^{23}$ Ailbus, Brains, Behavior, and Robotics, 276-79; Simpson, "Mechanical Measurement," 27; Simpson, interview, February 25, 2000; Albus, interview, February 25, 2000.

Joseph Engelberger, the accepted father of industrial robots, stated in an interview that automated manufacturing required looking seriously at the underlying computer systems. "Probably the person to speak to that best would be Jim Albus at the National Bureau of Standards because he's been hawking, and a lot of people have adopted the so-called hierarchy theory." See Alfred B. Bortz, "Joseph Engelberger: The Father of Industrial Robots Reflects on His Progeny," Robotics Age (April 1985): 21. Engelberger installed his first robot in 1961 and started Unimation, Inc., the world's first robot manufacturer. See also Ray Kammer, interview, June 16, 2000; Russell Young, interview by author, June 30, 2000, audiotape, NIST; Albus, interview, February 25, 2000.
} 
began to show interest in this control system work. Bob Hocken's group saw its budget completely cut. In an attempt to find new directions for his group, Hocken began meeting with John Evans and an automation coordination group evolved. ${ }^{25}$

These explorations into computers, machine tools, and robots converged formally between 1977-1978 when the Bureau of Standards underwent a major reorganization. Public attention focused on the Bureau to a degree not seen in recent years, driven in part by the concern many sectors of society felt towards the loss of American productivity, increasing foreign competition, unsteady economic times, and calls for social relevance in all areas of the federal government. These shifts in focus were strongly supported and encouraged by the thenAssistant Secretary for Productivity, Technology, and Innovation in the Department of Commerce, Jordan Baruch, himself a very capable engineer with an up-to-date knowledge of computers. With this increased visibility and a shower of internal and external examinations, NBS Director Ernest Ambler made a number of changes. He replaced the separate Institutes of Basic Standards, Materials Research, and Applied Technology with a new National Measurement Laboratory and a National Engineering Laboratory (NEL). Each lab consolidated research areas that had become technically advanced yet isolated from work in other related areas. For the new engineering laboratory, Ambler appointed John Lyons as its first director and tasked him with collecting all of the technology-related programs, except for materials. Ambler later recalled that in establishing NEL, he wanted "to get the Bureau back into hard science and engineering and make it relevant," structuring the lab into the hard engineering disciplines through its individual centers. ${ }^{26}$ Lyons was a physical chemist who had worked for about twenty years for the Monsanto Chemical Company before coming to the Bureau in 1973 to head its Center for Fire Research. As director of NEL, Lyons collected together electronics, chemical engineering, civil engineering, fire research, mechanical engineering, and robotics and established a series of centers. For the Center for Mechanical Engineering and Process Technology (CMEPT), Lyons put John Simpson in charge with John Evans as his deputy. Thus began the formal relationship between the metrologists and the roboticists. ${ }^{27}$

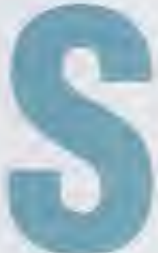

IMPSON AND EVANS made "productivity enhancement" the driving goal of their new center. Such a focus united the otherwise wide-ranging CMEPT, which included the continuous process industries, such as the petroleum and chemical fields; the energy industry; and the discrete parts industry. But, Simpson also understood the dire straits of American manufacturing and wanted his center to take an active role in finding technological solutions. In his files, with each item carefully numbered and catalogued for continuing referral, Simpson kept articles, reports, and any other indicators that pointed to the problems of the discrete parts industry and suggested solutions. In his 1978 long-range plan for CMEPT, which Evans compiled, Simpson opened with three assumptions that captured his vision for his corner of NBS: that productivity enhancement had to be a joint government-industry cooperative venture, that large-scale automation would be the major player in productivity enhancement, and that the development of the metrology needed to support this new manufacturing technology would come from the Bureau of Standards. He used the 1976 General Accounting Office report as a significant source for articulating the problems of manufacturing, and he emphasized the report's conclusion that NBS was "uniquely equipped for a major role in improving productivity in manufacturing.", ${ }^{28}$ He took seriously this charge. In later recollections, he bluntly identified

Hocken, interview, Warch 3, 2000; Evans, interview, February 18, 2000.

${ }^{3}$ Emest Ambler, interview by Karma Beal, September 22, 1988, transcript, 3-4, NIST Library. John Simpson later stated that he believed Ambler reorganized NBS to meet the calls for national relevance while also protecting what Ambler considered to be the core of the Bureau: physics, chemistry, etc. See Simpson, interview, 1993.

Lyons, interview, July 28, 2000; NBS Annual Report, Fiscal Year 1978, 6-7.

3 CMEPT Long-Range Plan (November 1978), 38. 
himself as belonging to the "radical left-wing of the Bureau that wanted to see something accomplished. ... I thought a government scientist was more useful to the common weal, so to speak. . . I wanted to play a larger role. ${ }^{29}$ In his earlier days with the Bureau (when it was still located on Van Ness Street in Washington, DC), he had stepped outside the artificial barriers of government science and became active in the American Physical Society, eventually becoming one of the first government scientists to sit on the society's Board of Governors. That larger vision shaped his entire career at the Bureau of Standards and informed his direction of CMEPT. ${ }^{30}$

\section{The idea for a factory}

Slowly, the pieces of research from the old automation technology and 3-dimensional metrology groups came together under Simpson's guiding hand. Work on the automated coordinate measuring machine pointed to the idea of applying error correction to machine tools, making the machine tool "intelligent" by self-correcting its errors. Early experiments on an old Burgmaster machining center proved that this idea of measuring the manufacturing process, instead of waiting until after a part was made, significantly increased accuracy. At just about this time, Henry Fuchs from the Bureau of Engraving and Printing (BEP) came to NBS with a problem. Fuchs needed someone to machine a pair of approximately 13-by 30-inch cylinders that made the perforations in stamps. Sheets of printed stamps passed through a revolving set of matched cylinders, with one cylinder having approximately 17,500 pins to perforate the paper and the other cylinder with the corresponding $1 \mathrm{~mm}$-diameter holes to accept the pins as they passed through the paper. Fuchs needed a set of cylinders to create the perforations in a large sheet containing several sets of collector stamps of irregular size for a philatelic exposition in Canada. BEP's original plan to sell unperforated sheets of stamps had not been well received by the stamp collecting community. Previously, an Italian firm had hand-crafted such cylinders, taking two and half years to deliver a set. By the time the BEP had decided to perforate this commemorative stamp issue, the Italian firm could not meet the deadline. Drawings for the cylinders specified that every hole in the pin cylinder match up with the corresponding hole in the die cylinder within 0.001 inches when assembled in the perforating machine. American manufacturers balked at this tight tolerance requirement, which was beyond the capability of existing production machines. This predicament left Fuchs desperate for a solution. Surely, the Bureau of Engraving and Printing's sister organization, which focused on measurement, could help. ${ }^{31}$ Fuchs allowed that a tolerance of 0.002-inches might be tolerated, but even this allowance exceeded the capabilities of the available machines in the NBS Shops. Since either not trying or failing to make useable cylinders had the same detrimental impact on the United States, Dave Bettwy, chief of the NBS Shops, agreed to the task on a best effort basis if Fuchs agreed to fund the effort. ${ }^{32}$

The resulting collaboration between both bureaus set in place the footwork for the dance called the Automated Manufacturing Research Facility (AMRF). Bettwy and NBS Shops foreman Bob Lach, the numerical control (NC) machine tool expert, met with Fuchs to see what could be done. Lach and his talented group of instrument makers first had to make special subplates for an NC machine tool to make it large enough to hold the cylinders. Next, they had to figure out how to index the cylinder with pins, to determine exactly where the rows

\footnotetext{
${ }^{29}$ Simpson, interview, 1993.

${ }^{30} \mathrm{Ibid}$, i, 36-48; "The AM Award: Dr. John Simpson," 61. Most of the articles used for framing the first section of this chapter came from this collection of Simpson files, still kept in the MEL office files.

"The AM Award: Dr. John A. Simpson," 63; Simpson, "Mechanical Measurement," 23; Robin P. Bergstrom, "Drilling Precision Stamp Cylinders at NBS," Mamufacturing Engineering (April 1984): 76-77; Lach, interview, July 21, 2000; David Bettwy, interview by author, July 14, 2000, audiotape, NIST.

Bettwy, personal communication to author, October 6, 2000, File Bettwy, AMRF Files, NIST.
} 
of holes should be placed on the matching cylinder. Bettwy designed a special driving dog to minimize angular errors as the indexing plate positioned each row of holes for drilling. Bettwy also recognized that Bob Hocken's laser interferometry techniques for achieving systematic error modeling could be applied to this project. Laser interferometry could document the $x-y$ position of each hole as it was drilled. This information would then be used to vary appropriately the $\mathrm{x}-\mathrm{y}$ positions in the $\mathrm{NC}$ program for the subsequent cylinder. Lach turned to Ralph Veale, who provided and set up the laser interferometer measuring equipment. Thomas Charlton, who had joined Bob Hocken's group in January 1979 and had worked on the systematic error modeling project, helped take measurements and create an error map. Lach still had to confront the problem of thermal errors resulting when the machine tool warmed up and expanded, affecting machining accuracy. To minimize this effect, the plant division turned up the air conditioning equipment and put accurate, recording thermometers in place to track the ambient temperature. Personnel kept the doors to the Shops area closed at all times. Once machining started, Lach and his team kept it machining constantly in order to eliminate all warm-up and machining-load temperature transitions. This latter step also proved a necessity, with machining needed 24 hours a day, seven days a week for several weeks to meet the BEP deadline. ${ }^{33}$

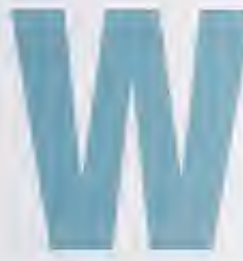

ITH THE CYLINDERS DONE, Hocken's metrology division only had enough time to sample several of the thousands of holes in each cylinder. Bettwy used Computer Aided Design (CAD) equipment to plot these measurements on two overlaying layers of the cylinders. He found that the centers of the measured holes did fall within 0.002-inches of each other, or, in effect, of drilling each hole within 0.001 inches of its absolute specified position on the drawing. When Fuchs used the variable positioning capability of the equipment used for perforating the commemorative stamp sheets, the perforating did perform satisfactorily. The Bureau of Engraving and Printing delivered one half of the required quantity of stamps on the first day of the exposition. As Bettwy later recalled, all of this effort "was well worthwhile when the credibility of the US was maintained, and the final sales of the commemorative issue amounted to approximately $\$ 6,500,000$." ${ }^{34}$

The challenge of the original 0.001 -inch tolerance limit remained. Two private industry companies had already tried and failed to develop special drilling machines. So, Hocken and Bettwy approached the Bureau of Engraving and Printing, suggesting that if it bought a large machine tool and put it in the NBS Shops, Hocken's group could refine the error correction process and get the required level of accuracy. Buoyed by the initial success and anxious to have a long-term remedy to stamp perforation that did not rely upon the two-and-a-halfyear turnaround time (and accompanying high costs) of the Italian firm, the BEP said yes. This task had greater challenges because the majority of the cylinders needed by the BEP were for the web printing press, the same type of press used for printing newspapers. The press printed stamps on paper fed continuously from a roll approximately 6-feet in diameter. Once printed and with glue applied, the stamped paper then passed through the perforating cylinders and rolled up onto another 6-foot diameter spool. As opposed to the original project, these cylinders were slightly smaller in diameter, but, depending on the size of the stamps in the run, would have as many as 50,000 holes per cylinder. The holes had to be positioned with great precision because the cylinders could not be adjusted relative to each other. ${ }^{35}$

\footnotetext{
${ }^{33}$ Bettwy, interview, July 14, 2000; Lach, interview, July 22, 2000; Charlton, interview, May 8, 2000, audiotape, NIST; Bergstrom, "Drilling Precision Stamp Cylinders," 76-78.

${ }^{34}$ Bettwy, personal communication, October 6, 2000.

${ }^{35} \mathrm{Tbid}$.
} 
As a group, Lach, Hocken, Charlton, and others picked out a large Brown \& Sharpe 1500 NC vertical machining center. This time period saw almost weekly changes in machine tools with respect to accuracy and other features, and the group felt that this was the best machine at the time for its purposes. The machine tool was standard issue except for the requirement of glass scales on the $\mathrm{x}$ - and $\mathrm{y}$-axes. Charlton first used lasers to characterize the machine tool's systematic manufacturing errors. These errors were caused by tool or table positioning, machine motion, and expansion or contraction of the machine due to temperature changes. After applying mathematical algorithms, the group developed an error map and applied a software correction technique to the machine tool. This technique basically required fooling the machine controller, or NC system. The software running inside the controller could not be touched because it was considered proprietary and was therefore "closed." So, other members of the team, including Kang Lee and Jim Shaver, captured the outputs of the controller via a set of microprocessors resident in the controller, applied the error correction map on the signals on a separate computer, then fed the adjusted outputs into the machine controller. These corrections might have seemed to direct the machine tool to the wrong position, but because of the errors, the machine actually drilled in the correct spot. Running under this system, the Brown \& Sharpe machine produced a remarkable five-fold increase in accuracy. Interestingly, the software so improved the accuracy of the machine that the temperature gradient on the glass scales became a significant source of error. Temperatures measured by

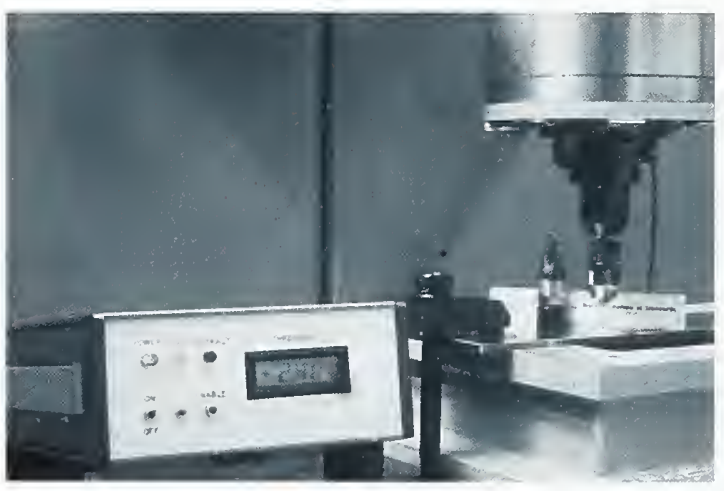

Figure 3. Drill-Up saved valuable time and money in machining by sensing before a drill broke, telling the machine tool to retract for the operator to change the drill. (Photo collection, AMRF Files, NIST) sensors placed on the scales were then included in the error correcting algorithms. The magazine editors of Industrial Research presented its IR-100 award to the many people who contributed to the development of the idea of error correction in automated equipment. ${ }^{36}$

Another common problem appeared with drill breakage. The huge 1,500-pound head on the Brown \& Sharpe "peck-drilled" with a little 1 mm-diameter drill at its end, up and down and up and down like a pecking hen. As John Lyons later remarked, "It was very strange. You would look at this great monstrous machine tool... and on the end of it we were controlling little bitty drills. ${ }^{, 37}$ The trick was not to look for changes in the vibrations of the machine tool's massive spindle but rather to look at the vibration signature of the interaction between the drill and the part being drilled. To avoid drill breakage, machinists would first visually inspect drills and then, to avoid the consequences of the so-called infant mortality rate, drill about 12 holes as a test to see if the drill broke. If the drill passed these two tests, the machinist would drill about 300 holes and then replace the drill. Still, drill breakage happened on average every thousand holes, causing damage that was difficult and time consuming to repair. When drilling tens of thousands of holes for the stamp perforators, such an error rate was unacceptable. As chief of the NBS Instrument Shops Division Dave Bettwy later recalled, one day an engineer walked by and saw a machinist reach over and hit the emergency retract button to stop the process. The engineer asked why he did that, and the machinist replied that he could tell by the sound of the drill that it was probably

\footnotetext{
"The AM Award: Dr. John A. Simpson," 63; Simpson, "Mechanical Measurement," 23-24; Bergstrom, "Drilling Precision Stamp Cylinders," 77-79; Charlton, interview, May 8, 2000; Lach, interview, July 21, 2000; Meade, NBS's AMRF, 19; Kang Lee, interview by author, April 7, 2000, audiotape, NIST; Hocken, interview, March 3, 2000 . People cited in the IR-100 award were Ken Yee, Don Blomquist, Kang Lee, Tom Charlton, Jim Shaver, Ralph Veale, B. Borchardt, R. Liu, W. Zinn, and Alkan Donmez. 
going to break, so he stopped the machine to change it. The engineer replied, "If you can hear it, we can sense it." Ken Yee and Don Blomquist went back and developed a sensor so that when the drilling started, it recorded the sound level. Every fourth of a revolution, the sensor would re-check the sound level against the initial reading, and record each time the level was exceeded. When the level was exceeded for four counts in a row, it would tell the machine to retract, and the operator would change the drill. To test the effectiveness of this approach, the researchers drilled holes without lubricant. After the sensor retracted the drill, they turned off the sensor and continued drilling. Typically, the drill failed within five holes of the sensor warning of failure. Drill-Up (Fig. 3), as this device was called, reduced breakages to zero. Valeron and Technovations corporations commercialized it, and this drill wear detector was used in the manufacturing community. Yee and Blomquist won the prestigious IR-100 Award, from Industrial Research magazine, for their work on this detector. ${ }^{38}$

With Drill-Up and systematic error modeling, the NBS researchers found a way to control the manufacturing process to make the part, or in this case drilling 50,000 holes on the cylinders, right the first time. This idea of measuring the machine instead of the part became known as deterministic metrology and held great promise for enhancing manufacturing productivity. First, time spent measuring process parameters was less than measuring attributes of the finished part. Second, these process parameters did not change with new products, again saving valuable time. Third, the number of incorrectly manufactured parts was reduced to almost zero and reworking was unnecessary. Fourth, manufacturers knew that their shipped parts were right and to what level of accuracy. Such calculations had been impossible to do previously due to the inaccuracies and limitations of coordinate measuring machines. Combined, these benefits added up to significant possible savings for companies and higher productivity rates. ${ }^{39}$

ROM CREATING A SINGLE INTELLIGENT machine tool to make stamp perforations came the idea for a completely automated factory. This idea resulted from the contributions of many farsighted and concerned individuals who worried about the status of American manufacturing. The combined expertise of the different divisions that later went into the creation of the Center for Mechanical Engineering and Process Technology and the technical acumen of NBS Instrument Shops personnel helped provide the environment for sparking such an ambitious program. Each person contributed his or her bit of knowledge about computers, machine tools, and robots to make an integrated automated factory even conceivable. That said, it did take some visionary thinking, and a certain amount of chutzpah, to suggest such a large and complex project that went beyond the state-of-the-art of the time. Nothing like it, in terms of personnel numbers or level of industry-government-university cooperation, had been done at the Bureau. The Automated Manufacturing Research Facility was truly ground breaking, and its effects continue to reverberate both within the now-called National Institute of Standards and Technology and throughout manufacturing worldwide.

Two separate ideas combined to make the final realization of the AMRF. First, Russell Young promoted the idea of a factory in the NBS laboratory. Second, Bob Hocken, with Bill Haight and Tom Charlton, conceived the idea of a full factory automation program. These two sets of contributions led to the conceptualization of the AMRF. Young had joined the Bureau in 1961 with a Ph.D. in physics to work in surface science. He developed what he called the topografiner, a non-contacting instrument for high resolution mapping of surface topography. This instrument was a forerunner of the scanning tunneling microscope, for which the Nobel Prize was awarded

\footnotetext{
${ }^{38}$ Simpson, "Mechanical Measurement," 23-24; Bettwy, interview, July 14, 2000.

${ }^{39}$ Simpson, "Mechanical Measurement," 24-25; Simpson, interview, February 25, 2000.
} 
in 1986. Young, though not a co-recipient, was cited in the award for his earlier work. In 1973, unable to get further support within NBS for his work on the topografiner, Young joined Simpson in the engineering calibration area. Following the 1978 reorganization of the Bureau, Young found himself in charge of the Mechanical Processes Division, which included the old automation technology group of Evans, Albus, Barbera, and others. It was from this group, and especially Albus, that Young believes "the seed from which the AMRF grew was planted. . . ."40 Albus and his colleagues recognized how the idea of integrated hierarchical control and robotics could have an enormous beneficial impact on the discrete parts industry and American productivity. In response, he and his colleagues proposed a substantial program to develop an intelligent control system to aid manufacturing. ${ }^{41}$

It was at a group leader's meeting, probably in late 1978 or January 1979, to consider a budget request to support such a program that Young remembers first becoming involved in AMRF decisions. At the meeting were Young, Hocken, Vanderbrugh, Haight, Don Eitzen, Dennis Swyt, and Clayton Teague. As Young recalls, this proposal included using some desktop models but not implementation with real manufacturing hardware. It was at this point that both Young and Swyt remember Young taking the firm position that a program would be useful for and influential to industry only if NBS demonstrated its effectiveness in a physical manufacturing facility. "I remember the strong feeling that I had," Young said later, "that it would be a mistake to go ahead" with just the table-top version. Young was very much in Albus's camp, but he thought the idea would fail. In his scientific career, Young had found that unless one implemented an idea, tested it, and made mistakes along the way, people would not accept the work. For this reason, he pushed hard for a research version of an automated factory, a factory in the laboratory, in the NBS Shops. Teague also remembers the meeting and the discussion of building a research facility at NBS, but he does not recall who actually made the proposal for the full-fledged facility. Yet, many people agree that Young's steadfastness in supporting such a program was a key to its eventual success. ${ }^{42}$

HE IDEA OF A FACTORY AUTOMATION program developed from Hocken and his co-workers Haight and Charlton. Hocken had a depth of understanding of the problems in American manufacturing in the 1970s. In 1976, Paul Pontius, chief of the NBS mass section, took Hocken to the Chicago Machine Tool show, the showcase for machine tool manufacturers. Pontius wanted Hocken to see who used the Bureau's calibrations. This experience stayed with Hocken. As he later recalled, "I was very much impressed by that. It was apparently a huge and very vibrant industry that relied on the measurements being done at NBS at the time. And I felt that we probably weren't really serving them very well. . . . They were advancing into the computer era, and we weren't." ${ }^{, 43}$ Hocken then got a taste of the international machine tool and manufacturing scene. Through CIRP, the International Institution for Production Engineering Research (translation from the French), Hocken had the opportunity to tour laboratories in England, Europe, Japan, and the United States. He was impressed by what these other labs were doing in comparison to NBS, which again did not seem to be doing enough. Then, Hocken chaired a machine tool task force out of Lawrence Livermore National Laboratory to survey the state of the art of machine tool accuracy around the world. That provided an even more intimate look at industry advances. He returned to Japan and

\footnotetext{
${ }^{40}$ Young, interview, June 30, 2000.

"Ibid.

2 Young, interview, June 30, 2000; Dennis Swyt, interview by author, March 10, 2000; and Clayton Teague, interview by author, July 28, 2000, both audiotapes, NIST. Simpson, in his remarks at his retirement party, named both Young and Hocken as the parents of the AMRF. See "Remarks," file John Simpson, AMRF files, NIST. Don Eitzen, personal communication to author, January 28, 2001.

3 Hocken, interview, March 3, 2000; Charlton, interview, May 8, 2000.
} 
toured the facilities of the builders and users of machine tools. When he came back in 1979, he focused on the Bureau of Engraving and Printing project and used the idea of the intelligent machine tool, through error modeling and sensing, that he knew from both his travels and inhouse work at the Bureau. ${ }^{44}$

Sometime In 1979, as Tom Charlton remembers, Hocken came to the office with three pages of handwritten notes, saying that he had worked out this plan for a manufacturing facility the previous night. As Hocken remembers, he and Bill Haight had started talking about matching the programs they had seen in Germany and Japan. "We came up with this idea of building a big experiment to see how automated we could make a manufacturing plant." In any case, Hocken, Haight, and Charlton shared an office suite, and their conversations began to turn to building such a laboratory at NBS. From there, Hocken recalls putting together proposals, sketching out a tentative budget, and making presentations. Only after this work does he remember Albus and others sharing Young's and their ideas about a factory in the laboratory. ${ }^{45}$

Documentation points to the origin of the AMRF idea in either late 1978 or early 1979. The Fiscal Year 1978 NBS Annual Report has a big section on automation work in the Bureau, but it does not mention an automated research facility. But, in February 1979, Howard Sorrows sent a memo to Young thanking him for his initiative request on the "Discrete Parts Batch Manufacturing Facility." 46 Sorrows ties this proposal idea to the cooperative technology ("CT") program that was implemented in 1978 to "stimulate joint efforts by the Federal government, industry, and academia in developing the science and technology base critical to U.S. industry." ${ }^{47}$ In a 1981 report on the Bureau of Standards, the House Subcommittee on Science, Research and Technology notes that in spring 1979, NBS presented to the Department of Commerce a proposal for its fiscal year 1981 budget titled Research for Industrial Productivity and Innovation. At its core was the idea to use "part of the NBS machine tool shop as an automated manufacturing test bed" to study computers, machine tools, and automation. ${ }^{48}$ A separate initiative on cooperative technology, which also included a proposal for a center in automated manufacturing, went forward to Commerce at the same time.

Both were rejected and were not included in the Secretary of Commerce's request to the Office of Management and Budget. However, in the February 1980 hearings before the House Subcommittee on Science, Research and Technology, committee chairman Donald Fuqua (R-Fl.) asked NBS Director Ambler what priority items he had if the agency received additional money. Ambler responded that "our first priority would be in research for automated manufacturing." He then presented to the subcommittee the 1979 NBS request to Commerce, which included the almost $\$ 2.8$ million for automated flexible batch manufacturing and \$21 million for the cooperative technology centers in such areas as automated manufacturing. The February 1980 Long Range Plan for the National Engineering Laboratory, covering 1980-1985, also includes three references to a "small automated mechanical machining facility."

\footnotetext{
${ }^{*}$ Hocken, interview, March 3, 2000.

${ }^{45}$ Hocken, interview, March 3, 2000; Charlton, interview, May 8, 2000.

${ }^{*}$ Howard Sorrows to Russell Young, February 15, 1979, File Russell Young, AMRF files, MEL, NIST.

${ }^{47}$ NBS Annual Report, 1978, 53.

${ }^{48}$ House Subcommittee, NBS: A Review of Its Organization, 101.

${ }^{49}$ Ambler quoted in House Committee on Science and Technology, Subcommittee on Science, Research and Technology, 1981 National Bureau of Standards Autborization: Hearings, $96^{\text {th }}$ Cong., 2d sess., February 1980, 64, 66-67. John W. Lyons and Kenneth R. Goodwin, National Engineering Laboratory Long Range Plan 1980-1985 (Gaithersburg, MD: NBS, 1980), 3, 16, 17, File Long Range Plans, AMRF Files, NIST. On page 22, the Long Range Plan directly refers to developing the concept of hierarchical control and the promise offered by the cerebellum model for artificial intelligence for automation theory. People considered many different names for the research facility, including "Automated Manufacturing Test Facility," before selecting the Automated Manufacturing Research Facility, Charles McLean, personal communication with Joan Wellington, January 5, 2001.
} 
fiscal year 1981 \$2 million for the purpose of an Automated Manufacturing Research Facility and for fiscal year 1982 another $\$ 4$ million. This date thus marks the official beginning of the AMRF. The dance had now been set.

Many people made the October 1980 congressional authorization possible. Once Young's and Hocken's ideas had been combined into the initial conception for an automated research facility, Hocken and Albus began putting together a proposal and talking it up with John Simpson. Simpson took awhile to warm up to the idea. As he recalled later, Hocken and Young "beat on me for months before I saw their wisdom in starting a full-scale demonstration instead of a table-top toy." ${ }^{, 50}$ NEL director John Lyons quickly agreed with the concept, but then the group had to think about funding. They knew that NBS funds could not afford a full-scale operational research factory, so Lyons, Simpson, Hocken, Albus, and Blomquist went to the $11^{\text {th }}$ floor of the Administration Building to see Dr. Ambler. Ambler was the eighth director of NBS. A trained physicist born and educated in England ${ }^{51}$, he had joined the Bureau in 1953 and had contributed to nuclear and cryogenic physics research before becoming Director of the Institute of Basic Standards in 1968. In this position, he had initiated the automation of the metrology section, which ultimately led Simpson and Lyons to his doors a little more than a decade later. They were taking that first step toward automation back in 1968 to its natural conclusion in a research factory. Lyons, Simpson, and the others presented the problem. They knew such a facility and its research, if allowed to grow to its full capability, would help manufacturing considerably. But they would have to look outside the agency for the necessary money and take the associated risk. If the other agency decided to pull out, NBS would have to let people go. Ambler agreed that the program was too important not to do and that the risk was justifiable. "I still remember Ambler sitting across the table," Simpson later noted, "and saying that he had watched the Foreign Defense forces during the War in England, drilling with broomsticks [for lack of guns]. He sort of vowed he'd never let that happen again. He realized the manufacturing was necessary [to keep the military supplied and defend the country]." ${ }^{52}$ Despite agreeing to seek outside funding, Ambler still tried his hand with the Department of Commerce, which rejected the idea. Congress then based its initial authorization on that 1979 Commerce proposal.

HERE WAS ONE MORE INTERESTING DEVELOPMENT on the funding front in 1980. In January 1980, Philip M. Klutznick became the new Secretary of Commerce, a position he held for only a year when the Carter administration was replaced by the Reagan Republicans. Klutznick was a real estate developer from Chicago who liked big ideas. He asked then NBS Deputy Director Ray Kammer to put together four or five really big initiatives, along the lines of $\$ 100$ million each, for Klutznick to review, thinking Carter would get re-elected. Kammer later recalled that the Bureau developed its initiatives more in response to Klutznick's enthusiasm than in any real expectation of getting the money, "it was a summer exercise." ${ }^{\prime 53}$ But, Lyons remembers the proposal Simpson's group, with Bob Hocken being a major contributor, developed. To house the imagined automated research facility at such a high level of spending, Simpson's group proposed erecting a 13-story building, "which would allow him to look down on the $11^{\text {th }}$ floor!" where Director Ambler sat. ${ }^{54}$ The proposal also articulated some forward thinking about outreach, suggesting that the Bureau establish a series of development and training centers to help industry upgrade to the level that it

\footnotetext{
${ }^{50}$ Simpson, remarks at his retirement, 1. See also Simpson, interview, February 25, 2000.

Ambler became a United States citizen in 1958.

Simpson, interview, 1993.

Kammer, interview, June 16, 2000.

Lyons, interview, June 1, 1993, 29. Donald Eitzen also temembers the 13-story building proposal. See his electronic mail message to Paul Vassallo forwarded to Ric Jackson, June 2, 1999, File John Simpson, AMRF Files, MEL, NIST.
} 
could incorporate the automation work of the research facility. The Manufacturing Extension Partnership, a hugely successful NIST program, embodied some of these early ideas. ${ }^{55}$

\section{Why a research factory}

During each of these proposal writing sessions and when doing their "dog and pony show" to generate funding from outside sources up and down the streets of Washington, DC, Simpson, Albus, and Hocken had to articulate in concrete terms what they envisioned for the AMRF, its choreography. Why was it crucial for the National Bureau of Standards to do this work? Throughout the lifetime of the facility, there were many skeptics, both within the Bureau and outside, and the team had to confront these criticisms. Bureau folks, not wanting their agency to use scarce dollars on a factory, wondered if the work could instead be done in company testbeds. Such an arrangement, said the AMRF supporters, failed to provide an impartial setting, without concerns about proprietary issues. Also, a hands-on facility, as Young had argued, allowed them to test engineering problems and make mistakes on the equipment manufacturers used, learning in the process. Yet, as Lyons later stated, there were essentially two root reasons for building the AMRF. First, there was the compelling force of international competition in the late 1970s and early 1980s. Japan and Germany were "literally eating our lunch in the automobile business." And automated factories, which weren't terribly sophisticated, contributed greatly to this situation. Simpson, Albus, Hocken, and Lyons firmly believed that the discrete parts industry, which had the greatest need for automation and largest impact on overall productivity, needed better measurement techniques and standards to make automation viable. Using sensors, error correction, a hierarchical control system, and standard interfaces for connecting machine tools to computers and robots, these firms could potentially make parts right the first time, thus save time and money and increase productivity.

Second, it was fun. As the Bureau of Engraving and Printing experience proved, real measurement issues challenged each of the researchers to find solutions, testing their creative limits and expanding the borders of knowledge. Jack McInnis of the Navy Manufacturing Technology program recognized this attitude, saying that these people were at NBS working on the AMRF because it was fun and they were doing neat stuff. ${ }^{58}$

0 ACCOMPLISH THESE GOALS, the trio of Simpson-Hocken-Albus ${ }^{59}$, who became the leaders behind the AVRF, developed a concrete vision of the program. They wanted their ultimate customers, the more than 100,000 small discrete parts manufacturing firms, to have flexibility in automating their productions. This flexibility would one day allow these companies to machine a part right the first time, make a couple hundred of them, and then immediately machine a different type of part. Flexibility also had to come from the machines these manufacturers would hook up to their production processes. AMRFers knew that automation in these plants would come in stages, one or two machines at a time. Computers, robots, and machine tools from different companies had to hook up together, talk, and work as an integrated system. Simpson often likened this flexibility to hooking up a stereo, getting music from different components made by different manufacturers. To develop the standards to make this vision possible, the trio intentionally chose robots from different companies, computers from more companies, and machine tools from still more companies. Each of the six workstations would test ways to get a computer, a robot, and a machine tool

\footnotetext{
${ }^{35}$ Lyons, interview, June 1, 1993, 29; Lyons, interview, July 28, 2000; Eitzen, personal communication, January 28, 2001.

${ }^{36}$ Hocken, interview, March 3, 2000.

"Lyons, interview, July 28, 2000.

John Lyons, interview, July 28, 2000; Jack McInnis, interview by author, May 5, 2000, audiotape, NIST.

${ }^{59}$ Russell Young retired from NBS in January 1981.
} 
(or other automated equipment such as a measuring machine or storage/retrieval units) to communicate and accomplish tasks. Along the way, work on sensors, an integrated database, and the overall control system would make the final facility.

Their approach set the AMRF apart from any other research facility around the world. The idea of applying error correction to machine tools as well as coordinate measuring machines, to fulfill the dream of making parts right the first time, stepped ahead of other projects, such as in Germany, which focused on precision measurement as opposed to manufacturing. Applying mathematical modeling, what Hocken called fundamental physics math, to this error correction work also made the AMRF different. ${ }^{61}$ The AMRF relied on industryuniversity-government participation, another hallmark of the project. As Roger Nagel from the robotics group later stated, "It was very important to all of us that the AMRF not be an academic exercise but rather be of immediate and short-term future value to industry." helped ensure the immediacy of the project. Using standard, off-the-shelf components made the AMRF singular from the German and Japanese approaches, which built their own hardware. And, Americans acknowledged that computer software would ultimately make or break the vision of flexibility, which the Japanese in particular failed to address. ${ }^{63}$

With Ambler's blessing and this vision in mind, Simpson, Albus, and Hocken went on the road to drum up funding. Simpson used his connections to open doors and got the team audiences with the Army, the Air Force, and the Navy. Albus and Hocken made their enthusiastic sales pitch with a range of charts, overheads, and sketches. Although the Air Force had collaborated with the former automation technology program earlier, it required immediate results from its investment which the AMRF could not deliver. The Navy listened. One of its continuing problems had been getting parts made for its ships, submarines, and aircraft carriers without losing valuable time in drydock. Either the vessel could carry a host of spare parts, taking up valuable space, or it could order the needed part from blueprints. The AMRF, with its focus on computer-driven manufacturing, promised an answer. ${ }^{64}$ The Navy also had a program, Manufacturing Technology or ManTech, and people with the same kind of visionary thinking as the Simpson team to recognize the potential of the AMRF. Navy ManTech worried about how to find ways to build its fleet and weapons systems more cost effectively with higher quality and better production techniques. These systems had been under careful review in the mid-1970s due to low reliability rates and poor quality. Will Willoughby from NASA came over to find a solution. He promoted the idea of having Navy ManTech fund national centers of excellence for areas such as electronics and machined parts, to focus the research and implementation. As former Navy ManTech director Jack McInnis laughingly recalls, the AMRF salespeople came knocking on his door right after Willoughby presented his ideas. After more presentations and visits to see the AMRF emerge on the shop floor, the Navy decided to name the AMRF its first Center of Excellence and provide a significant amount of the funding over the life of the project. "When somebody hands you something that is 85 percent of what you are looking for," said McInnis, "it's too good an opportunity to walk away from. They did a lot of good work for us over the years." ${ }^{\text {. }}$

That work, the dance, now began in earnest.

\footnotetext{
60 "The AM Award: Dr. John A. Simpson," 60, 63-64.

${ }^{61}$ Charlton, interview, May 8, 2000

${ }^{62}$ Roger Nagel, interview by author, February 28, 2000, audiotape, NIST.

${ }^{63}$ See Howard M. Bloom, Leonard S. Haynes, David S. Bettwy, and Mahn Hee Hahn, Summary Foreign Trip Report, November 9, 1982, File David Bettwy, AMRF Files, MEL, NIST; Hocken, interview, March 3, 2000.

${ }^{64}$ Albus, interview, February 25, 2000; Hocken, interview, March̉ 3, 2000; Lyons, interview, July 28, 2000.

scInnis, interview, May 5, 2000
} 


\section{Chapter Three}

\section{MAGICAL MANUFACTURING}

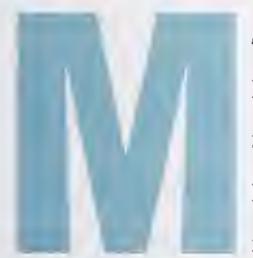

AGIC MIGHT CHARACTERIZE how observers saw the dancing robots and machine tools in the AMRF. Controlled by computers, these industrial behemoths almost effortlessly whizzed and turned in elegant coordination while producing a single unique widget sure to impress. A robot cart could deliver, within an hour of order placement, an inspected and approved aluminum dovetail box complete with American flag machined on its top. Who could not think that the AMRF was a magical place full of possibility and hope for all of American manufacturing? Here was a testbed for the factory of the future, demonstrating to the world that automation had promise. But, magic, as any Houdini or David Copperfield wannabe knows, requires vision, practice, determination, and even smoke and mirrors to pull it off. For the AMRF, its more than one hundred National Bureau of Standards employees also needed the generous contributions of its many sponsors in government, industry, and the universities to make the dance magical.

Many such partnerships with outside organizations began once the United States Congress provided the seed money for the AVRF in Fiscal Year 1981. Within months of the official October 1980 start-up of the facility, large firms eagerly sent the first Industrial Research Associates. This situation followed exactly the vision of National Bureau of Standards Director Ernest Ambler who had noted early on that, "I'd like to see representatives from American industry crawling all over that shop." The Bureau of Standards had a long history of partnerships with industry, and Director Ambler wanted the same level of participation in the AMRF. A Lockheed Corporation investigator looked at automatic tool settings, a Hewlett-Packard scientist examined length measurement problems, and a Deere \& Company worker explored calibration issues for automated coordinate measuring machines. These companies and others recognized the research dividends they would reap from working with the National Bureau of Standards. They also had the wide employee base that could afford the time and money of having a researcher away from the factory. Once a business and NBS had defined a research project of mutual interest, an employee would work in the AMRF for typically six months to a year. Firms paid their employees' salaries while the Bureau provided general lab space and equipment. In the first year alone, some corporations also lent or donated almost a half million dollars' worth of equipment. More money from Congress and the \$2-\$6 million annual commitment from Navy ManTech beginning in 1983 provided steady financial backing. ${ }^{2}$

To house these research associates, equipment, and growing funds for examining automation, the Bureau needed a proper dance floor. Two organizational shifts accomplished this goal. In late 1980, National Engineering Laboratory (NEL) director John Lyons split the continuous processing areas from the Center for Mechanical Engineering and Process Technology (CMEPT). He put John Simpson in charge of the new Center for Manufacturing Engineering (CME), keeping it focused on measurements and standards services for the discreteparts industry. By February 1981, Simpson and Robert Hocken realized the need for another change. Hocken, the

Ambler, quoted in Peter Behr, "Even in R\&D, Standards Bureau Measuring Up," Washington Post (March 30, 1981), Washington Business, 7.

Steven Ashley, "Mini-machining Cell," American Metal Market Metalworking News (April 20, 1981), 10, File B-18, John Simpson Files, MEL office, NIST; US Department of Commerce, "Improved Manufacturing Productivity Is Goal of Navy/NBS Research Program," News Release (May 25, 1983), File Demo Nov83, AMRF Files, NIST; National Bureau of Standards, Annual Report, 1981/1982, 4; 1984, 2, NIST Library; Philip Nanzetta, "Update: NBS Research Facility Addresses Problems in Set-Ups for Small Batch Manufacturing," Industrial Engineering (June 1984): 73. 
dimensional metrologist who had formulated the idea of error mapping of coordinate measuring machines (CMMs), served as chief of the Automated Production Technology Division and took a lead role in planning the AMRF. Work on the automated research facility, as Simpson, Hocken, and the rest of the team quickly recognized, required constant coordination and cooperation with the NBS Instrument Shops, where the AMRF was housed. To facilitate this relationship, Simpson and Hocken proposed to the chief of the Instrument Shops Division, David Bettwy, that his division transfer into CME. Such a move, they argued, would bring interesting and attractive work, heighten the Shops' visibility within the Bureau, and add funding. Bettwy agreed.

Challenges soon arose from the joining of the research staff of engineers and scientists with the hands-on Shops personnel. For safety reasons, the Bureau built a wall consisting of head-high dividers with windows on top and light green metal at the bottom to separate the 5,000-square feet of the AMRF from the rest of the Shops (Fig. 4). This step, which reduced the available work space for the Shops by a third, helped to ensure that robots and

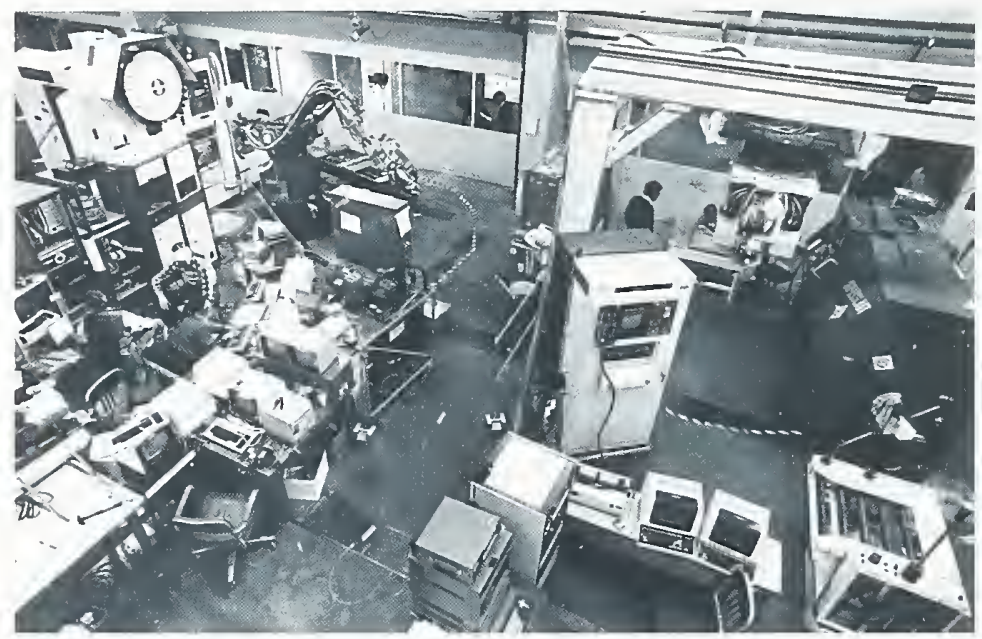

Figure 4. A wall with windows kept the robots and machine tools of the AMRF's Horizontal Workstation (left) and Turning Workstation (right) separate from visitors while another wall with windows, not seen, divided the production floor of the NBS Shops from the AMRF. (Photo collection, MB-2, ISD, NIST) robot carts did not bang into or harm people or equipment in the Shops area. Yet, the wall also symbolized the differences in approaches that existed between the AMRF staff, who were focused on research and experimentation, and the Shops people, who were focused on production. To meet their mission, the Shops people built much of the special instruments required by researchers throughout the Bureau. Much of the hardware for the cold neutron reactor, for instance, came from the NBS Shops. Viewing themselves as craftsmen, they took pride in the wide assortment of skills they practiced, ranging from machining to welding to glass blowing to optical finishing. And, they functioned as close to an outside shop as possible. So, they had to meet deadlines and do the work competitively. Such an arrangement encouraged workers to keep to a production mode of operation. Stopping midway in a machining process to observe the direction chips fell in an effort to test an idea for an automatic vacuum, for example, would not routinely be met with good cheer. Most Shops personnel enjoyed tackling the problem of actually building a part, taking design specifications and translating them into a solid object. Fewer savored the necessary interruptions, conversations, and thinking that came with the research side of the AMRF.

Ashley, "Mini-machining Cell, 16; John W. Lyons and Kenneth R. Goodwin, National Engineering Laboratory: Long Range Plan 1981-1986 (National Bureau of Standards: June 1981), 27, File Long Range Plans, AMRF Files, MEL, NIST; Lyons, interview, July 28, 2000; Bettwy, interview, July 14, 2000; Lach, interview, July 21, 2000. With the move to CME, the Instrument Shops Division name officially changed to the Fabrication Technology Division. However, Bettwy, Lach, and others continued to refer to the area as the Shops. See NBS Organizational Listings for February 1, 1981 and May 1 1981, File Organizational Listings, AMRF Files, NIST.

A separate safety wall with windows allowed visitors to watch the robots and machine tools perform.

Robert J. Hocken and Philip Nanzetta, "Research in Automated Manufacturing at NBS," Manufacturing Engineering (October 1983); 69; Lach, interview, July 21, 2000; Bettwy, interview, July 14, 2000. 
SUSPICION OF AUTOMATION aggravated these differences in approaches. When Bettwy took over as chief of the NBS Shops in 1977, he recognized immediately that the introduction of numerical control machine tools had fractured the group, leaving a difficult working environment. A trained mechanical engineer, Bettwy had worked his way through college at the Bureau of Standards ordnance division until it had been transferred to the Army Material Command of the Harry Diamond Laboratory. When he came back to NBS after twenty-five years at Harry Diamond, he immediately set out to bring unity to the Shops workers. With the introduction of a completely automated research facility on the floor, this task proved most imperative, and required a great deal of courage. The AMRF researchers needed the cooperation of the Shops personnel to demonstrate the machining tools and how to manufacture objects, like the aluminum dovetail box. To build teams between Shops personnel and researchers, Simpson funded outside management consultants. They established quality engineering circles, in which Shops people had the opportunity to hear about the AMRF's goals, discuss the details, and then provide input on how, from the Shops perspective, these goals could be attained. Shops workers participated in the installation of the various robots and machine tools and developed a sense of ownership in the project. As Bettwy later remembered, there was a "tremendous change in their attitude and a lessening of all this friction,", as the teams worked together. The transformation was not complete, though, and the differences in approaches remained. When a Shops person would see a researcher come into the AMRF late in the morning and tinker with computers and machine tools, some misunderstandings and hard feelings remained. What the Shops person didn't see was the same researcher fiddling with hardware and software late into the night. At the same time, due to the constraints of research and the demands of production, not much effort was or could be made toward transferring AMRF ideas into the Shops. That wall still existed and left people on both sides a bit curious, a bit suspicious, a bit separate?

Driving these negotiated interactions between Shops and AMRF personnel was a dedication to manufacturing. Everyone wanted to make manufacturing more productive and accurate to build the stuff that industry and science and everyday life demanded in the age of computers. Three strategies guided the overall development of the facility. First, the AMRF would support basic research in metrology, or measurement, for the factory of the future. Here, the ideas of deterministic metrology and systematic error modeling, as tested in the Bureau of Engraving and Printing project, would be enhanced and expanded toward the ultimate objective of machining a part right the first time. Second, the research facility would serve as a testbed for interface standards, fulfilling the dream that machine tools, robots, computers, and software packages from different companies could link together and communicate. Flexibility required such standards, so that small discrete-parts manufacturing firms could build an automated factory one piece at a time, as their finances allowed. And, by introducing automation into this important segment of American industry, Simpson and others believed that productivity would rise, thereby strengthening the United States economy. Third, the AMRF would provide a research environment where teams of representatives from government, academia, and industry could investigate fundamental problems in manufacturing technology, thereby advancing the science into the twenty-first century. ${ }^{8}$

\footnotetext{
Bettwy, interview, July 14,2000 .

Lach, interview, July 21, 2000; Bettwy, interview, July 14, 2000; Mark Luce, interview by author, June 2, 2000, audiotape, NIST; Cita Furlani, interview by author, March 24, 2000, audiotape, NIST.

Center for Manufacturing Engineering, Documentation of the First Year Effort on the Automated Manufacturing Research Facility (AMRF) (October 198I), 1-1, AMRF Files, NIST; Hocken and Nanzetta, "Research in Automated Manufacturing," 68-69; Robert J. Hocken, "NBS Building Facility for Research into Problem of Automating Small Machine Shops," Industrial Engineering (April 1982); Cheryl Pellerin, "Scientists Help American Manufacturers Build Factory of the Future," Washington Technology (January 22, 1987), 14.
} 
With these goals set, the team laid out a design for the facility. Workstations would serve as the organizing structure and would have the ability to work both independently and in coordination with one or several of the other workstations. Each one would be defined by its particular task or cutting ability. In addition, individual workstations would feature, in great technical depth, one aspect of the overall research project and pair it to a fairly unsophisticated piece. This approach kept the AMRF from putting all of its hot technical advancements into one place. Machining workstations thus would have a metal-cutting machine tool, an industrial robot or two, a local storage buffer for tools and materials, a material handling interface, and a workstation control computer to integrate and coordinate operations. Other workstations would address material inventory, transfer, housekeeping, and inspection. ${ }^{9}$

All equipment would be standard from a variety of vendors, available commercially throughout the United States. Hocken, in particular, favored American pieces. When Japanese or other foreign companies significantly underbid American manufacturers, Hocken went directly to the American companies and solicited their cooperation. A company such as Hardinge would donate a machine tool and send people to work in the research facility. Otherwise, the AMRF would have been forced to use the lower-costing foreign equipment, as required under federal government procurement rules, and would have lost an important area of research interaction with American manufacturers. Chief of Shops Bettwy remembers one Japanese maker of coordinate measuring machines that "wanted in a worse kind of way to be part of it, to get in here." ${ }^{10}$ Hocken kept saying no, until one day, one of its CMMs appeared on the NBS loading dock. The Japanese firm had sent it, and they wouldn't take it back. Hocken still refused to put it in the AMRF, but he did use it in other metrology work and found it to be a very good piece of equipment. Clearly, even foreign companies, which had their own national programs in automation, recognized the importance of the AMRF. In Japan, its MUM (mechanized unmanned manufacturing) or FMC (flexible manufacturing center) project in automation rejected current machine tool technology in favor of specially designed ones. So, Japanese makers turned to the US as a possible source for research and advancement. But, American manufacturers had priority. ${ }^{\text {"I }}$

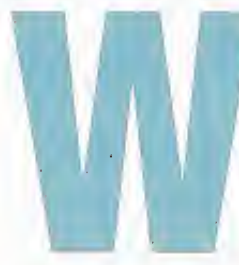

HAT THE AMRF TEAM MANUFACTURED with the machine tools fit within the model presented by the NBS Instrument Shops. Studies demonstrated that the Shops' part mix matched those in a typical machined-parts job shop, again keeping the AMRF relevant to the industry. Metal cutting would be the focus, addressing the dominant activity in small discreteparts manufacturing companies nationwide. These were the companies, as identified in the 1976 General Accounting Office report, that needed the most help in increasing productivity through incremental adoption of automation. So, parts would weigh no more than 100 pounds and measure no more than one-foot square for a prismatic shape or ten inches in diameter and height for a cylinder. There could be up to four axes of complexity and between one and one thousand pieces in a part run. Materials would be limited to steel, stainless steel, aluminum, brass, iron, and lucite. The AMRF would not address such problems as automated assembly, welding, hardening, and finishing. Blanks would enter the system as near net shape. ${ }^{12}$

\footnotetext{
Cita M. Furlani, Ernest W. Kent, Howard M. Bloom, and Charles R. McLean, "The Automated Manufacturing Research Facility of the National Bureau of Standards," paper presented at the Summer Computer Simulation Conference, Vancouver, BC, Canada, July 11-13, 1983, 2, MSID Library, NIST; CME, First-Year Effort, 4-7; Thomas Wheatley, interview by author, May 26, 2000, audiotape, NIST.

${ }^{10}$ Bettwy, interview, July 14, 2000.

J. A. Simpson, R. J. Hocken, and J. S. Albus, "The Automated Manufacturing Research Facility of the National Bureau of Standards," Journal of Manufacturing Systems 1 (1982): 21; Hocken, "NBS Building Facility;" Meade, The NBS' AMRF, 20; Bettwy, interview, July 14, 2000.

"GA0, Manufacturing Technology - A Changing Cballenge, i-iv; Simpson, Hocken, Albus, "The AMRF of the NBS," 20-21; Hocken, "NBS Building Facility;" Meade, The NBS' AMRF, 19-20; CME, First-Year Effort, 2-5 - 2-6.
} 
0 MAKE THE MAGIC POSSIBLE of machining, finishing, measuring, and delivering a part automatically, the AMRF, as originally planned, contained eight workstations, as described below. With time, the Material Inventory Workstation and Transfer System were combined as one station and Housekeeping was removed as a separate system, making a total of six workstations or systems. Equipment came incrementally over the course of the first five years of the project, but the team had a vision of the layout and research functions of each workstation from early on. On the AMRF section of the Shops floor, as originally configured, all workstations except Inspection sat on an oval race track plan surrounding the automated storage bins which held tools, blanks, and finished inventory. The Inspection Workstation, to ensure the most accurate measurements, sat to the side in an enclosed temperature-controlled room. ${ }^{13}$ Descriptions follow:

Horizontal Workstation (HWS, Fig. 5) combined a White Sundstrand Series 20 Omnimil CNC (computer numerical control) horizontal spindle machining center, a Cincinnati Milacron T3 robot, an NBS-developed vision system attached to the robot arm, an automated part/tool buffer, and an automated part fixturing system, each with its own Real-time Control System (RCS). All systems were integrated with the AMRF database and network. The Horizontal Workstation tested integration of many different components within the control architecture and RCS developed by James Albus, Anthony Barbera, and others. The vision system was one of the systems they integrated. As research progressed, the T3 robot could pick up objects randomly placed on a tray and could sense if blanks were missing or misaligned. Blanks were held vertically in automated fixtures on moving pallets and were shuttled in front of the spindle of the machine tool with the rotating tool of the spindle in the horizontal position. The fixtures had a control system to provide feedback on successful loading of blanks. In addition, the researchers enhanced the machine tool with automated features to make possible robotic loading of tools into the machine's tool carousel. Vertical blank positioning had the advantage that chips fell away, with the help of coolant spray, during

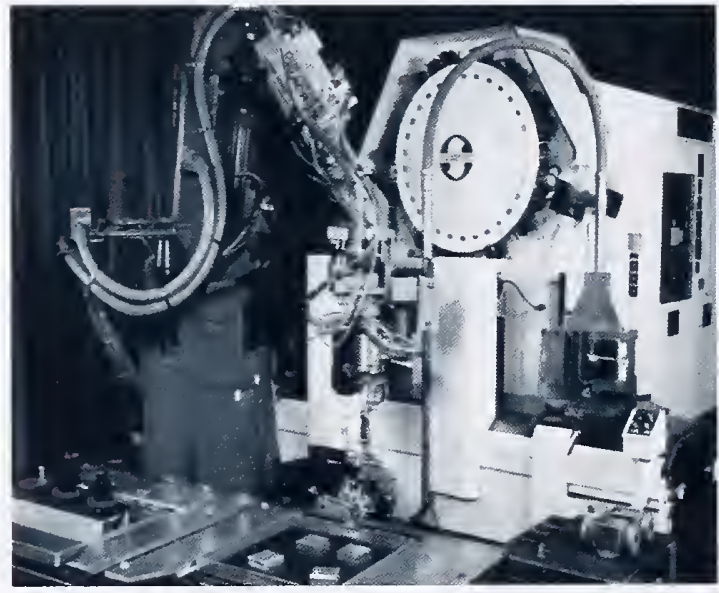

Figure 5. A Cincinnati Milacron T3 robot tended to the White-Sundstrand Series 20 Omnimil horizontal spindle machining center. This workstation, with its NBS-developed vision system, tested integration of many different components within the AMRF's hierarchical control architecture and Real-time Control System. (Photo collection, ISD, NIST) machining thanks to gravity. But, robot loading proved a challenge, and engineers devised an automated fixturing device that could take commands from a computer to position its holding jaws, hold the part with a commanded amount of pressure, and release the part vertically into the machine tool fixtures. The HWS eventually included a local automated materials buffering system that could store part blanks, finished parts, and tools for the Omnimil. The robot could load tools from the buffer into the Omnimil to adapt to changing machining needs and to replace dull or broken tools. Researchers used FORTH as the programming language for this workstation. ${ }^{14}$

\footnotetext{
Hocken, "NBS Building Facility."

Meade, The NBS AMRF, 22, 63; William Rippey, interview by author, March 10, 2000; Harry Scott, interview by author, June 16, 2000, both audiotapes,

NIST; Wheatley, interview, May 26, 2000.
} 
Team members included William Rippey, Harry Scott, Anthony Barbera, Mary Lynn Fitzgerald, Emest Kent, Thomas Wheatley, Kathleen Strouse, Doug Fishman, Bob Bunch, John Vranish, Al Wavering, John Fidu, Richard Burton, Chip Carew

Vertical Workstation (VWS, Fig. 6) comprised a Monarch VMC 75, CNC vertical spindle machining center with a Unimation Unimate 4000 robot. Here, the spindle sat vertical to a horizontally placed blank. The Vertical

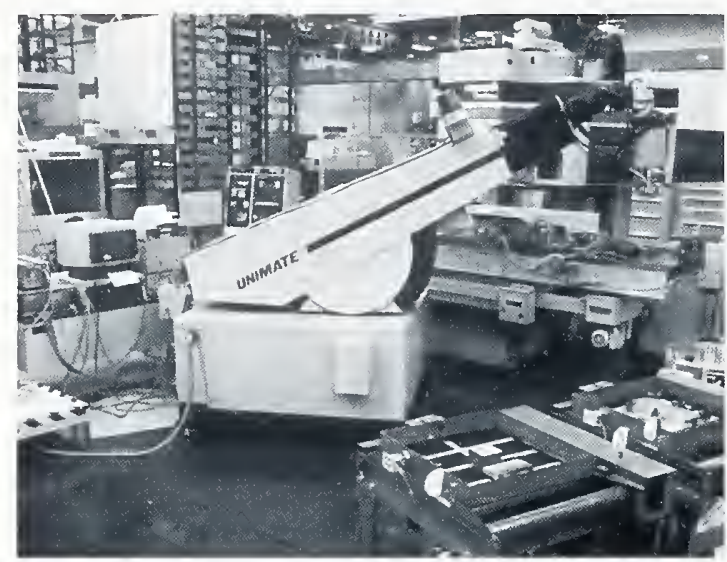

Figure 6. The Unimate 4000 robot loaded blanks into the Monarch VMC 75 computer numerical control (CNC) vertical spindle machining center. A pioneering automated process planning system generated the numerica! code, verified it, and directed the machining center to cut the part as designed by the user, totally hands off. (Photo collection, AMRF Files, NIST)
Workstation pioneered research on building an automated production system from design to the finished part. By 1985, a person could choose a design based on some fairly simple features, such as holes, pockets, or exterior contours, and the system would automatically make a process plan for sequencing the operations to make the object. Then, the system automatically generated the numerical control program for cutting the blank and verified that the code was correct. The part would be completed in fifteen minutes, totally hands off. Team members also wrote a brush program to sweep away metal chips before the robot unloaded the part. Researchers programmed in Lisp. ${ }^{15}$

Team members included Thomas Kramer, Charles McLean, Ed Magrab, Fred Rudder, Denver Lovett, Jau-Shi Jun, Carl Wenger, Alton Quist, Clara Bird

Turning Workstation (TWS, Fig. 7) included a Hardinge Superslant, CNC Turning Center with a Bendix electric, fixed gantry mounted robot. The Turning Workstation machined blanks like a lathe, making rounded objects. Researchers achieved 24-hour continuous production by making more than 250 Standard Reference Material containers over a 24-hour period. They accomplished this goal first by developing a micromanipulator, a small five-axis robot, which they mounted on the wrist of the gantry robot. The micromanipulator enhanced the Bendix robot's accuracy from 10 milli-inches to the 2 milli-inches needed to load part blanks successfully into the collet of the machine. The collet then held the blank for the machine to perform its turning operation. The team also developed communication and command structures between the workstation controller, machine, and robot to allow the controller to coordinate all equipment in the workstation to achieve full automation. This work eventually led the team to develop an automated process planning system for the Mare Island Flexible Manufacturing Workstation,

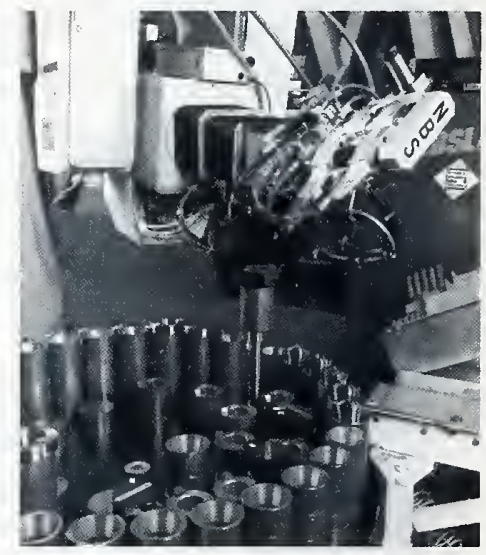

Figure 7. An NBS-developed robot micromanipulator sat on the Turning Workstation's Bendix robot's wrist, allowing the robot to meet the tight tolerances of loading part blanks into the machine's collet. (Photo collection, AMRF Files, NIST) discussed in chapter four. In addition to the above achievements,

'Meade, The NBS' AMRF, 63; Thomas Kramer, interview by author, April 14, 2000; Charles McLean, interview by author, June 2, 2000, both audiotapes, NIST. The Vertical Workstation itself did not have commercial utility because it did not address tolerance limits in its machining, but its process planning system did transfer to Texas Instruments and Bendix 
researchers also used Bob Hocken's work on error correction of coordinate measuring machines and applied them to the Turning Workstation. They modeled the machine tool's errors using laser interferometry, developed algorithms to compensate for those errors, and implemented the algorithms onto the TWS, ultimately improving accuracy by an order of magnitude, or ten times better. The workstation used Intel-based tools and wrote code in the PL/M language, developed by Intel. ${ }^{16}$

Team members included Kang Lee, Alkan Donmez, Charles Yang, Bob Gavin, Mike Huff, Lewis Greenspan, Man Hee Hahn, Toni Savoy, Jim Peris, Alex Slocum

Inspection Workstation (IWS, Fig. 8) had a Bendix Horizontal Arm CNC Coordinate Measuring Machine with an American robot, gantry mounted active $7^{\text {th }}$ axis. The original goal for this workstation involved using the part geometry, as coded into the computer, to drive the inspection process. The CMM had a touchsensitive probe at the end of a Cartesian set of axes. The machine would move the probe around in space and wherever it touched the part, the probe would record the position. By touching the part enough times, a computer could reconstruct what the part currently looked like and compare that to what the part should look like, taking tolerances into consideration. ${ }^{17}$

Team members included Ted Hopp, Howard Moncarz, Tom Charlton, Ted Vorburger, Steve Osella

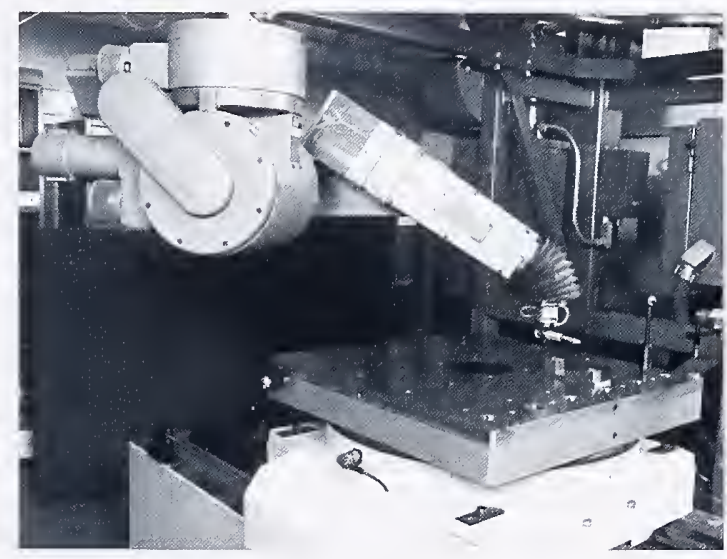

Figure 8. The gantry-mounted Bendix Horizontal Arm computer numerical control (CNC) Coordinate Measuring Machine used part geometry data files to measure a finished part from one of the AMRF workstations. (Photo collection, AMRF Files, NIST)

Cleaning and Deburring Workstation (CDWS, Fig. 9) shared two Unimation robots, a smaller Puma 760 with the deburring tool attached and a much larger Unimate $2000 \mathrm{~B}$ doing the buffing work. When a machine tool cuts metal, the last cut leaves behind a small piece of metal; deburring takes off that little piece. This workstation used part geometry encoded in the computer to debur the part. Researchers successfully fed the part geometry into the Puma robot, putting the robot about an inch away from the part edge. The robot, with deburring brush in hand, then touched the part, taught itself the points on the part, corrected for its errors, and removed the extra metal. Researchers programmed in Lisp. ${ }^{18}$

Team members included Rick Norcross, Harry McCain, Roger Kilmer, Karl Murphy, Pete Tangy

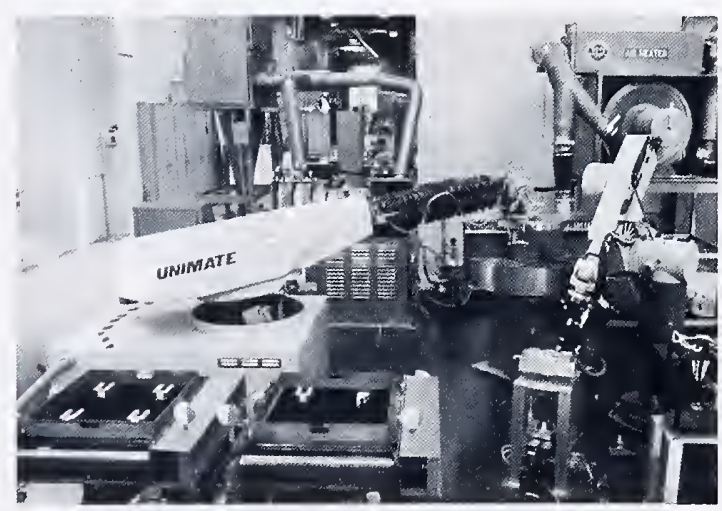

Figure 9. Researchers used two collaboratively working robots and part geometry data files to debur, or take off the last piece of metal left by the machine tools in the AMRF. (Photo collection, ISD, NIST)

\footnotetext{
${ }^{15}$ Meade, The NBS' AMRF, 22, 63; Kang Lee, interview by author, April 7, 2000, Alkan Donmez, interview by author, May 12, 2000; audiotapes, NIST.

${ }^{17}$ Meade, The NBS' AMRF, 63; Ted Hopp, interview by author, June 30, 2000, audiotape, NIST.

${ }^{18}$ Meade, The NBS' AMRF, 63; Richard Norcross, interview by author, August 25, 2000; Roger Kilmer, interview by author, July 28, 2000, both audiotapes, NIST.
} 
Material Inventory Workstation was expected to store a week's worth of blanks, tools, tool holders, special fixtures, and in-process or finished parts. ${ }^{19}$

Materials Transfer System would use a robot cart or automated guided vehicle to transfer supplies and finished parts throughout the AMRF. ${ }^{20}$

Material Handling System (MHS, Fig. 10) ultimately combined the storage and transfer capabilities of the Material Inventory and Materials Transfer systems. The MHS changed over the years. It originally used a Kardex storage system and a robot cart integrated with the Horizontal Workstation. As the AMRF expanded with more workstations, researchers added new robot carts and storage systems. Its buffer of six automated storage and retrieval system units became known affectionately among AMRFers as the "racker stacker." In its final form, the MHS used an IBM$\mathrm{PC}$ to control the system with the software written in C. Interfaces between the workstations and robot carts accommodated a range of different systems, helping to ensure modularity and flexibility. The robot carts had special safety features, including sensors to determine if a person or object was in the track of the cart, making the cart stop. Other sensors warned of low battery power, in which case the cart automatically went to a recharging station.

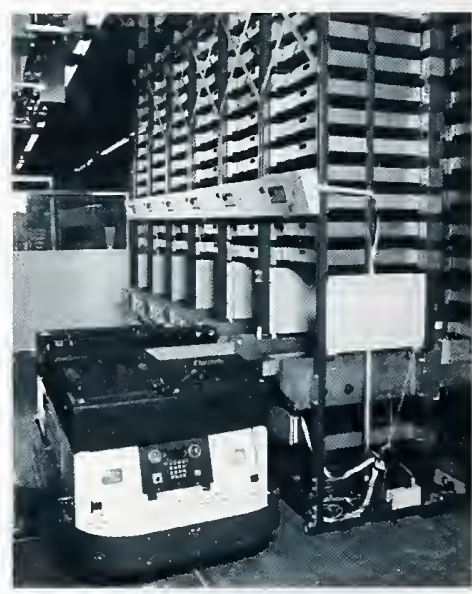

Fig. 10 The "racker stacker" stored about a week's worth of blanks, tools, and other pieces needed by the individual AMRF workstations. (Photo collection, AMRF Files, NIST)

Team members included Sandor Szabo, Cita Furlani, Man Hee Hahn, Charles McLean, Carl Wenger, Max Peltz

Housekeeping System was meant to address the need to remove metal chips during automated machining. These chips, along with coolant and cutting fluid, interfere with sensors and interrupt data flow in the automation process. ${ }^{22}$ The work of this station was incorporated into the individual machining workstations and its status as a separate workstation was eliminated.

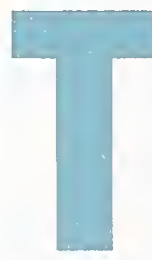

HINK FOR A MOMENT about what these workstations and all their doings meant in terms of factory control. How would the robot cart know to take steel blanks from the Materials Handling Workstation to the Turning Workstation? At the same time, how would the vision system in the Horizontal Workstation be able to locate a tool so that the T3 robot could pick it up? At the same time, how would the Vertical Workstation's robot know how large to open its gripper to grab a brass blank and position it into the machine tool properly? At the same time, how would the two robots in the Cleaning and Deburring Workstation know that they should debur a finished aluminum part as opposed to clean it? And, at the same time, how would the Inspection Workstation touch a box lid without shattering the probe? These are just a few of the myriad potential headaches engineers would have to tackle with research in factory automation. A

\footnotetext{
${ }^{19}$ CME, First-Year Effort, 4-1 - 4-2.

${ }^{20} \mathrm{CME}$, First-Year Effort, 42

McLean, interview, June 2, 2000; Pellerin, "Scientists Help:" 14; Furlani, interview, March 24, 2000. Simpson, Hocken, Albus, "The AMRF of the NBS," 21: Hocken, "NBS Building Facility."

CME, First-Year Effort, 4-4; Simpson, Hocken, Albus, "The AMRF of the NBS," 22.
} 


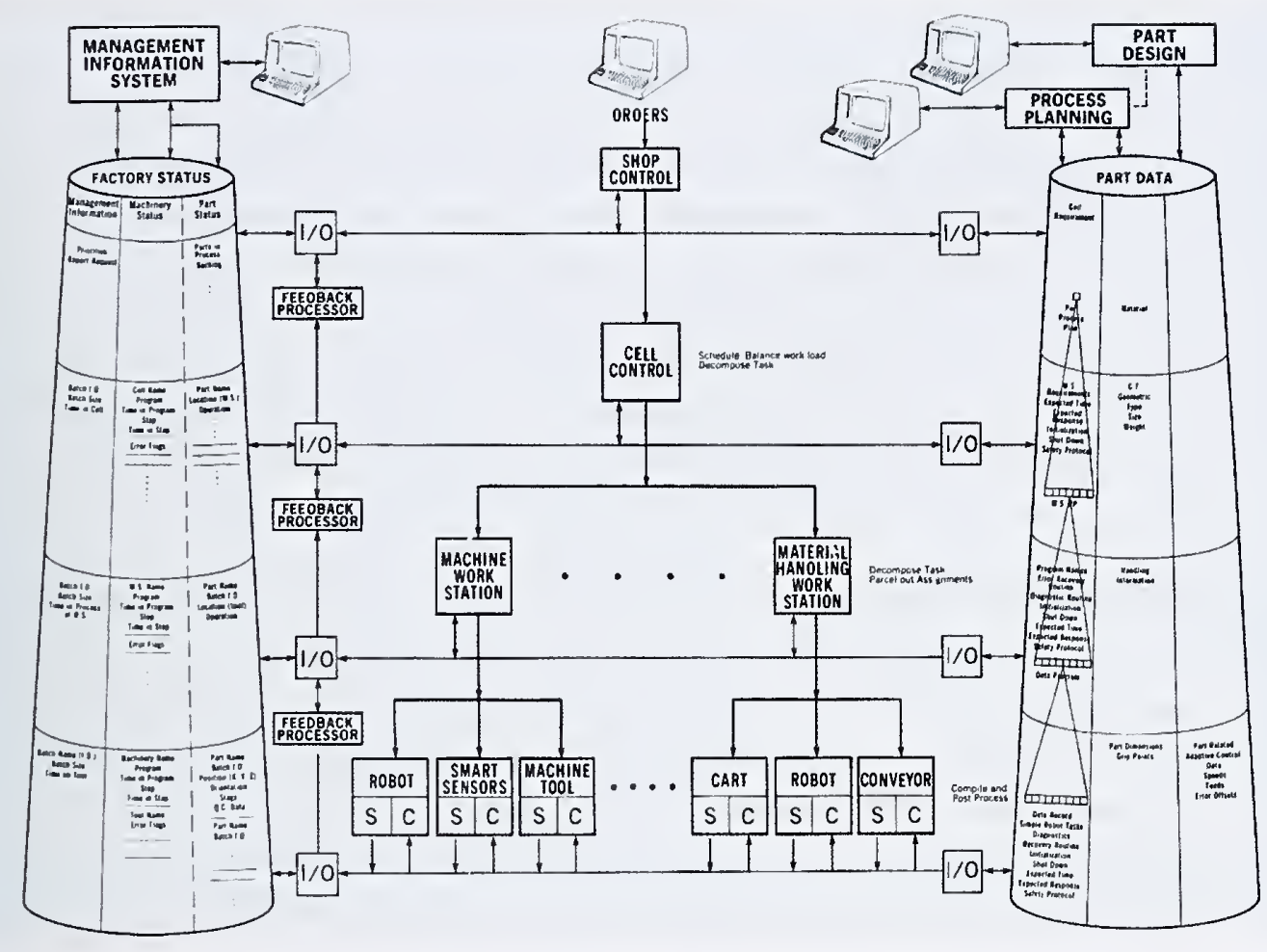

Figure 11. Roger Nagel and James Albus visualized the modularity of the AMRF with the Smokestacks Design, which kept part database information separate from factory status information. (AMRF Files, NIST)

typical top-down architecture would easily become overwhelmed with the amount of information and attendant sensor feedback. With James Albus's hierarchical control architecture and the NBS-developed Real-time Control System (RCS), though, this overload could be contained by limiting the complexity of the individual modules of the system. Complex industrial plants, such as steel mills, oil refineries, and glass works, had used a form of hierarchical control previously, but these systems used at most two to three layers in straightforward control applications without a high degree of sensory input. The AMRF set itself apart with its use of five hierarchical levels, identified as facility, shop, cell, workstation, and equipment. Each level, which could be further broken down into sublevels or modules, read a range of sensory data and completed a significant amount of real-time computation, allowing the system to interact dynamically and effectively with the Shops environment. ${ }^{23}$

Another potential headache involved flexibility in manufacturing. One of the key attractions of automation was that it promised industry the convenience of making one hundred pieces of one type of widget and then immediately making one thousand pieces of an entirely different gadget, without any significant downtime of machines. How could this goal be accomplished? Roger Nagel and James Albus helped point the way. They realized that the control system for the robots (and machine tools and other hardware in the factory) was really independent of what the robots did. Any pieces of equipment could be put together in a cell to complete a task, then they could be broken apart and reused in different tasks, but the control architecture remained stable. On a Sunday morning at Nagel's kitchen table, he and Albus together visualized this idea of flexibility with the Smokestacks Design (Fig. 11). The right-side smokestack, representing the Part Database, held the process plans

\footnotetext{
${ }^{23}$ Simpson, Hocken, Albus, "The AMRF of the NBS," 23-24; Charles McLean, Mary Mitchell, Edward Barkmeyer, "A Computer Architecture for Small-Batch Manufacturing," IEEE Spectrum (May 1983): 60-61.
} 
needed to make a part. With an order entered into the shop control level, increasingly complex pieces of information would be retrieved from the Part Database. Following this process plan down the hierarchy, first only its name would be identified. Then at the cell control level, the sequence of steps at the cell level would be accessed. Next, the workstation level would enter the Part Database at its level and gather the necessary instructions for the robot or machine tool. During all of this retrieving of information, the Factory Status Database, on Nagel and Albus's left-side of the Smokestacks Design, kept track of operations. What was happening in the whole factory? What was the status of each machine tool, robot, or other piece of equipment? Where was each part as it progressed through the factory and what transport systems were involved? This information was needed for keeping track of those robot carts and swinging robot arms, but this data did not rely specifically on what kind of part was being manufactured. The modularity of the Smokestacks Design, with part information separated from status information, promised the flexibility that AMRF designers envisioned. ${ }^{24}$

AKEN ONE STEP FURTHER, this modularity could allow researchers to reconfigure workstations across different cells (or AMRFs) during factory operation. Known as a virtual cell, this idea was simultaneously and independently invented by Nagel and Charles McLean, who joined the AMRF team in February 1981. McLean contributed his programming talents and experience in artificial intelligence to many different aspects of the AMRF. He first developed the AMRF cell control system, which managed and coordinated the performance of all part production and support tasks of the AMRF workstations. While working on the cell control system, McLean recognized that the AMRF's modularity, as seen in the Smokestacks Design, could be extended so that a virtual cell could request resources it needed from a pool of available resources and release them when no longer needed. Nagel had this very idea in mind in his own thinking about the twin smokestacks. The key was that, if a factory had several cells on its floor, the system could reconfigure those cells as needed as the factory operated. The flexibility of the AMRF could be extended to flexibility across a collection of cells. ${ }^{25}$

Nagel's contributions to the National Bureau of Standards and its factory automation program extended beyond the Smokestacks Design to his work in 1979-1980 on the Initial Graphics Exchange Specification (IGES). With a Ph.D. in computer science, Nagel had hit the ground running by teaching at the University of Maryland, operating a consulting company, and setting up a medical image processing laboratory for dental research at the National Institutes of Health before joining Albus's robotics group in 1978. Then, in 1979, at a meeting held in Detroit, MI, a representative from Ford Motor Company stood up and announced that his company was spending millions of dollars each year trying to coordinate different CAD (computer-aided design) software programs. More people stood up and shared this same frustration. Although a range of CAD systems existed, they each had their own software and method of representing data. As Ford and other companies discovered, if they needed to transfer a part design from one system to another, information would have to be re-entered manually, costing valuable time and money in the process. In response to this situation, the National Academy of Sciences sponsored a meeting in October 1979. Here, officials from the three branches of the military, NASA, NBS, and a large group of suppliers and users of $\mathrm{CAD}$ systems discussed the status of interface standards and agreed to form

\footnotetext{
${ }^{24}$ Simpson, Hocken, Albus, "The AMRF of the NBS," 23-24, 30; Furlani, Kent, Bloom, McLean, "The AMRF of the NBS,"2-3; Meade, The NBS" AMRF, 21; Albert T. Jones, Charles R. McLean, "A Proposed Hierarchical Control Model for Automated Manufacturing Systems," Journal of Manufacturing Systems 5(1986): 23; McLean, Mitchell, Barkmeyer, "A Computer Architecture," 60-61; Nagel, interview, February 28, 2000; Albus, interview, February 25, 2000; CME, First-Year Effort, 3-21 - 3-22; J. S. Albus, A. J. Barbera, and R. N. Nagel, "Theory and Practice of Hierarchical Control," Proceedings, $23^{\text {rd }}$ IEEE Computer Society International Conference, Washington, DC, 1981.

${ }^{25}$ Nagel, interview, February 28, 2000 and personal communication with author, January 26, 2000; Albus, personal communication with author, January 26, 2000; C. R. McLean, H. M. Bloom, and T. H. Hopp, "The Virtual Manufacturing Cell," Information Control Problems in Manufacturing

Technology, Fourth IFAC Symposium, October 26-28, 1982, 105-11; Charles McLean, personal communication with Joan Wellington, January 5, 2001.
} 
an IGES Technical Committee, under the sponsorship of the Air Force Integrated Computer-Aided Manufacturing Program (ICAM). Nagel chaired this joint industry-government committee. Two industrial partners, Boeing and General Electric, provided additional technical expertise. Tasked to create a standard within ninety days, Nagel's group used consensus-building exercises at three stages of the process to ensure the standard met the requirements of its users and suppliers. The standard was completed on time, and in September 1981, after more sharing of ideas, the American National Standards Institute (ANSI) adopted IGES Version 1 as a major portion of its standard Y14.26M, Digital Representation for Communication of Product Definition Data. Nagel's collaborative industry-government approach to defining standards has been the basis of further work in this area. IGES itself continues to be revised, going from wire-frame graphics construction to such shapes as geometric solids, plane figures, and curved surfaces. Its communication file structure interacts with processors supplied by the manufacturers, enabling different vendor systems to "talk" with each other. ${ }^{26}$

By the end of 1980, Nagel had left NBS, with Bradford Smith taking over the IGES work, but Nagel's legacy and commitment to the manufacturing program remained. He first went to International Harvester as head of its Intelligent Machines and Robotics division, then he took an endowed chair in manufacturing systems engineering at Lehigh University. He continues to serve on appraisal committees for NBS and has taken very seriously the ceremonial role of "Bureau Ambassador" bestowed upon him at his good-bye dinner. Howard Bloom, Nagel's successor in the Systems Software Group, which evolved into the Factory Automation Systems Division, used an NBS Director's competency grant to research CAD/CAM (computer-aided design/computeraided manufacturing) integration. ${ }^{27}$ While IGES allowed for design data exchange, enormous waste in resources and time continued because design and manufacture of parts remained incompatible. Designers needed to communicate which part dimensions were critical and which had flexibility so that manufacturers could structure their machining processes correctly. Ultimately, Bloom's work helped realize the idea of having the CAD data drive the actual manufacturing processes, one of the dreams of the AMRF. ${ }^{28}$

\section{Putting people and pieces together}

Bloom joined the AMRF team in December 1980 at a critical juncture. The first bit of congressional funding had jumpstarted the project, but Hocken and Albus were still knocking on doors trying to win outside money; the Navy ManTech program did not become a steady sponsor until 1983. In January 1981, newly-elected President Ronald Reagan, in his effort to downsize government, instituted a hiring freeze in all federal facilities. Bloom became a group leader of one — himself — within Albus's division. To lift the freeze, NBS had to balance the number of new positions with the number of positions eliminated. Director Ambler believed so strongly in the automation program that he removed more than 100 people to make room for the necessary hiring. Newly selected Secretary of Commerce Malcolm Baldrige shared Ambler's commitment to the AMRF, which proved absolutely vital since the Reagan White House strenuously objected to the program, arguing that it smacked too much of an industrial policy, with the government picking and choosing winners. Baldrige had graduated from Yale University with a degree in English and had eventually become the chief executive officer of Bridgeport Brass, which made a

\footnotetext{
${ }^{26}$ Nagel, interview, February 28, 2000; "Standard Data Formats: Transferring Part Designs between Systems," NBS Research Reports (0ctober 1984), 10; Mclean, Mitchell, Barkmeyer, "A Computer Architecture," 59; Meade, NBS' AMRF, 16.

${ }^{27}$ Nagel applied for and won this grant before leaving NBS.

${ }^{28}$ Nagel, interview, February 28, 2000; Howard Bloom, interview by author, March 3, 2000, audiotape, NIST.
} 
profitable line of automotive tire valves. Baldrige knew from this experience that the tolerances on those valves were extremely tight and required precision machinery. He recognized the value of the AMRF. ${ }^{29}$

Within this setting, Bloom and his slowly growing group, starting with computer scientist McLean ${ }^{30}$, attacked a huge problem. Bloom had responsibility for determining and implementing the future database and networking needs of the AMRF, in addition to working on the CAD/CAM integration project. Some perspective on the status of early 1980s computing and software technology sets the challenge. Albus's theory of hierarchical control made the conceptualization of an automated factory possible. But, the actual nuts and bolts of hooking up robots and machine tools and then each workstation to the others remained a significant hurdle. Having effective communication among these different parts required the very interface standards that the AMRF was supposed to help develop. As System Architect, Charles McLean wrote the internal interface specifications which provided the blueprint for allowing the individual workstation teams to build their pieces, knowing that the whole system would fit together. Electrical engineer Thomas Wheatley, who had joined Albus's robotics group in 1978 and worked on the robotics hardware for the Horizontal Workstation, expressed the situation from his viewpoint this way:

Setting the stage, you can see now that it was not just the code that was experimental, the compilers were written by us on hardware that was built by us on communication wires that were built and coded by us. So, everything was, if you will, an experiment. On that fairly fragile infrastructure, we were attempting to interface robots and machine tools and assembly and/or delivery systems. ${ }^{31}$

Within the larger AMRF, workstations used off-the-shelf commercial products, such as Sun Microsystems, Digital Equipment Corporation, or Intel computers. But, the scientists still had to make their systems work together in ways not foreseen by the manufacturers of these products. AMRFers built interface boards to control machine tools or sensors and did other systems engineering with "software glue." 32 They may have been crazy to try this, but part of the necessity of the AMRF was to point the way for industry, which was reeling from foreign competition and needed help now. Waiting even a couple of years for the technology to catch up to the theory might lose a competitive advantage for the United States. ${ }^{33}$

Russell Young, one of the fathers of the AMRF idea, hired Bloom knowing that the AMRF needed an infusion of software people to handle the complex problems described by Tom Wheatley. In Young's mind, the other top-level managers did not fully appreciate the severity of need for computer scientists, so he arranged for a team of IBM specialists in computer programming staff requirements to visit the Bureau of Standards. They reviewed the program and recommended a drastic increase in software-trained people. Young used this report to convince others that Bloom should eventually head a separate software development division, a step taken in 1986 with the creation of the Factory Automation Systems Division. Bloom had the experience to take on this

\footnotetext{
${ }^{29}$ Bloom, interview, March 3, 2000; NBS News Release, "Improved Manufacturing Productivity Is Goal of Navy/NBS Research Program, May 25, 1983, File Navy, AMRF Files, NIST.

${ }^{30}$ Due to the hiring freeze, McLean first joined Bloom's group through a grant as a faculty research associate from the University of Maryland. He was hired as an NBS employee by the fall of 1981. He assumed responsibility for the design and development of the cell control system. As System Architect, he developed internal specification documents that described the major functional modules and the interfaces between those modules. He went on to contribute his talents on the Vertical Workstation, the Material Handling System, and to work on the Process Planning System. McLean, interview, June 2,2000 .

Wheatley, interview, May 26, 2000 .

Edward Barkmeyer, personal communication to author, November 2, 2000, File Edward Barkmeyer, AMRF Files, NIST.

Bloom, interview, March 3, 2000; Edward Barkmeyer, interview by author, June 9, 2000, audiotape, NIST; Barbera, interview, May $22,2000$.
} 
software challenge. A trained electrical engineer with additional graduate work in computer science, Bloom had spent sixteen years at the Army Research Laboratories of the Harry Diamond Laboratory. He had worked in the areas of analog and digital simulation and eventually headed all computer development, both scientific and business. Bloom was just one of many Harry Diamond employees who eventually found their way to the AMRF. NBS chief of Shops Dave Bettwy had preceded Bloom to the Bureau, and Bettwy liked what he found. He kept encouraging Bloom to investigate a move. With the AMRF project starting, Bettwy told Bloom not to miss the opportunity. Intrigued, Bloom interviewed and got the job. By 1988, Bloom had sixty people working under him, a 2-to-1 ratio of computer scientists to mechanical engineers that realized the vision Young had foreseen almost a decade earlier. ${ }^{34}$

But, back in the early 1980s, the software associated with building an automated factory had tremendous obstacles to overcome. First, there was the basic mindset that Young addressed, getting people to realize the sheer scope of the computer situation. Everyone, from industry and government, from engineers to scientists, understood robots and machine tools. They moved, they whirred, they danced in artful combinations. They held the spotlight and captured the admiration of visitors and employees. How could pages of cryptic computer code or telephone wires strung across the floor in network cables compete with such glamour? They could not, yet, it was that very code and those very wires that made the dancing robots and whirling machine tools work. Second, computer technology was undergoing a revolution. Desktop computers were still in the future. Constant innovations characterized the computer industry with second-generation 8-bit processors speedily being replaced by 1982 with 16-bit machines. Anthony Barbera, who worked on the Real-time Control System, remembered stringing together eight computers to run the control system for the Horizontal Workstation. Those eight computers would equal in power one desktop personal computer (PC) fifteen years later. ${ }^{35}$

And, what to use to do that "stringing"? As Edward Barkmeyer recalled, Bloom's team experimented with a succession of networking advancements. With a master's degree in applied mathematics and further graduate work in computer science, Barkmeyer understood the challenges ahead for networking the equipment of the AMRF. He had started at NBS in 1974, working in the Institute for Computer Sciences and Technology, not with James Albus's robotics group but in the Advanced Systems Section, bringing new database and communications technologies into the Bureau. When he moved over to the AMRF in 1981 as a communications specialist, Barkmeyer had the opportunity to work with the roboticists and other engineers on finding effective and efficient methods for computer communication. By 1982, serial links transported computer code, at 9,600 bits per second, over a telephone quality line. Such a system was slow and limited in the amount of information it could carry. So, keeping the serial wire as a backup, the AMRF network used the Xerox Ethernet. All equipment hooked up to and communicated over a long cable. This network technology permitted simultaneous communication between layers of the control hierarchy and also within those levels, and it provided all controllers with direct access to the database systems. But, it could introduce delays in communication. If too many equipment controllers wanted to send a message at the same time, there would be contention and interference and some messages would not get through. A higher level protocol made sure that any lost messages were repeated, but that still created delays. In response to this problem and the increasing length of the cable, the AMRF team turned to Computrol's Megalink broadband network technology, on which they imposed the token-bus approach to control sharing. The tokenbus is a baton-passing style of communication, in which each equipment controller can send a data message only when it receives the token message, and must pass the token to the next controller down the line, thus

\footnotetext{
${ }^{34}$ Bloom, interview, March 3, 2000; Young, interview, June 30, 2000.

${ }^{35}$ Wheatley, interview, May 26, 2000; Barbera, interview, May 22, 2000.
} 
ensuring that each piece of the system is reached within a predictably short time. In 1986, AMRFers replaced the Megalink network with the IEEE standard token bus and the Manufacturing Applications Protocol (MAP) network promulgated by General Motors. MAP was supposed to provide the standard interfaces that would link the wide range of equipment, from Unimate robots to Hardinge machine tools to Sun scheduling computers. The joining of different technologies over time became apparent later. After the 1995 closing of the AMRF, Wheatley conducted a kind of archaeological dig in the Shops where the Horizontal Workstation had stood. On top, he found fiber optics, then a layer of coaxial cable, and all the way down a twisted pair of telephone wires. The AMRF reflected the revolution in networking technologies. ${ }^{36}$

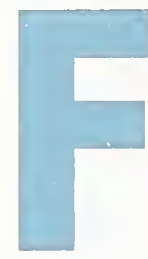

URTHER EVIDENCE OF THIS REVOLUTION was visible in common-memory protocol. Tony Barbera's development of this protocol synchronized communications among the different AMRF processes running at different speeds. The AMRF network extended this protocol to a "virtual common memory," segments of which were maintained as needed on the many different computers in the research facility. The artificial intelligence community refers to this technique as a "blackboard protocol" and it is now seen as the primary means of information exchange among independent "agents" in a control architecture.

All of this research activity soon signaled a program management challenge. CME director John Simpson had established a management-by-consensus approach, using a Management Planning Council to determine the activities within the Center. He and his division chiefs turned their individual executive authority over to the entire council, where the group would participate in discussions and come to agreement collectively. This method had the advantage that no decisions would be handed down to the divisions, but rather good ideas would filter up and flourish. Taking the initiative was rewarded. Simpson later recalled that such a management style, modeled after Japanese methods, created an environment "where bright people could do bright things." ${ }^{\text {"38 }}$ It kept people like Albus, Hocken, and others moving "in the same direction and not at each other's throats," ${ }^{39}$ although many council meetings did have voices raised to get points across. Yet, in the case of the AMRF, no single person was looking out for the project's overall interests. Division chiefs worried about research projects their own staff tackled and getting enough people and money to do this work. Simpson had to consider the larger issues, keeping abreast of all the divisions and CME work not related to the AMRF.

By 1982, Hocken, Thomas Charlton, and others recognized that the AMRF itself was growing beyond the organizational capabilities of the Planning Council. As Charlton remembered, "I think there was general agreement that we needed better management. The scientists could do what they did, and we would have a clearer more organized approach to ultimately getting the job done." ${ }^{, 40}$ Hocken and Charlton discussed possible candidates, and Charlton mentioned Phil Nanzetta. Nanzetta, who had a doctorate in mathematics, had been Dean of Science at Stockton State College in Pomona, New Jersey, when Charlton had taught applied physics

\footnotetext{
${ }^{36}$ Barkmeyer, interview, June 9, 2000; Barkmeyer, personal communication, November 2, 2000; "AMRF Gears Up for Full Operation," Modern Materials Handling (December 1986), Binder AMRF New Releases 7/85-3/87, AMRF Files, NIST; Jones and McLean, "A Proposed Hierarchical Control Model," 2324; Wheatley, interview, May 26, 2000; Christopher Joyce, "Factories Will Measure as They Make," New Scientist (September 4, 1986): 49; Albert T. Jones, "Selected Topics in Integration from the AMRF," in Richard H. F. Jackson, ed., Manufacturing and Automation Systems: Tecbniques and Technologies: Three Pillars of Manufacturing Technology, vol. 45 of Control and Dynamic Systems: Advances in Theory and Applications, edited by C. T. Leondes (San Diego, CA: Academic Press, Inc., 1992), 300-01.

Barkmeyer, personal communication, November 2, 2000

${ }^{38}$ Simpson, quoted in interview, February 25, 2000. See also "The AM Award: Dr. John A. Simpson," American Macbinist and Automated Manufacturing (December 1986): 64-65.

${ }^{39}$ Simpson, interview, February 25, 2000.

${ }^{40}$ Charlton, interview, May 8, 2000.
} 
there. Charlton had then followed his graduate school friend Bob Hocken ${ }^{41}$ to NBS but remembered Nanzetta's management skills with the university professors. "He was very capable, he was a good leader of people," Charlton later stated. Nanzetta "was very good at seeing the forest for the trees, and motivating a group of pretty diverse people, Arts and Sciences faculty, to work collectively." Knowing that he was ready for a change, Charlton advised Hocken to invite Nanzetta to visit the Bureau. What Nanzetta saw convinced him in June 1982 to take the position as deputy chief of Hocken's Automated Production Technology Division. ${ }^{43}$

Nanzetta had his work cut out for him. First, Simpson did not agree that the AMRF needed independent management, and so Nanzetta's position remained first as deputy division chief and then nominally that of AMRF program manager without any real authority to support it. Second, Nanzetta contended with a cast of strong-willed characters. As metrology expert Bob Hocken noted, "probably the whole system would never have worked as a system without Phil Nanzetta. ... There were too many prima donnas. Me included. Jim [Albus] and I, for instance, worked really well together as sales people, but we could argue like cats and dogs over technical questions. . . . One thing we always used to agree on was that we wanted to see it funded and we wanted to see it work. ... Phil was a good referee." Frustration set in as people argued and Nanzetta could not enforce progress. Division chiefs could not be held accountable for their staff delivering results on time as promised. The entire project lurched in fits and starts as each group worked on its own research. To instill some sense of urgency and accountability, Nanzetta instituted annual week-long demonstrations. These demos drove the project and gave valuable visibility to its accomplishments. They were an important management tool, in Nanzetta's mind, for getting the engineers and scientists to come to closure on their research and move the entire project forward. Bloom agreed, noting that "We are researchers, a researcher's attitude is 'I just want to work on it, keep improving it, and keep improving it, and writing papers.' If one of the major things is an integrated manufacturing facility, you have to demonstrate that. If people are constantly changing things, we can never get to that point. ${ }^{, 5}$ Plus, the Navy had the opportunity to see the results of its sponsorship and show them off to the world. Thanks to the demos, news about the AMRF and its vision of a lights-out factory made headline news and spread the promise of automation. Companies took notice, and most liked what they saw. ${ }^{46}$

Nanzetta also made it a point to keep the Navy pleased. The annual demonstrations helped in this regard. But, equally important was finding ways to address the specific needs of the Navy sponsor. Navy ManTech director Jack McInnis was a manage-by-results kind of person. He didn't want to see lots of viewgraphs or spend plans or other details about how the AMRF used the Navy money. ${ }^{47}$ Instead, he would communicate the Navy's needs and then wait for the results. As Howard Bloom remembered, McInnis did not put serious constraints on the Bureau. "He believed that what we were doing was the right thing, that it was industry oriented. It needed to have a Navy flavor but he recognized that the measurements and standards were critical, and that he wasn't going to push us to do things that were so Navy specific." ${ }^{48}$ Bloom recalled that McInnis even said once "It would be presumptuous

\footnotetext{
${ }^{41}$ Hocken and Charlton had shared a thesis advisor in physics at the State University of New York at Stonybrook. Hocken completed his Ph.D. in physics there in 1973; Charlton completed a master's and became an assistant professor of applied physics at Stockton State College. See Hocken, interview, March 3, 2000 and Charlton, interview, May 8, 2000.

${ }^{2}$ Charlton, interview, May 8, 2000.

${ }^{43}$ Phil Nanzetta, interview by author, February 20, 2000; Hocken, interview, March 3, 2000.

"Hocken, interview, March 3, 2000.

Bloom, interview, March 3, 2000.

th Nanzetta, interview, February 20,2000. The First-Year Documentation Effort manual mentions only that "All major equipment components will be installed and operating by the end of FY 84. The AMRF will become fully operational in the automatic mode by the end of FY 86." (1-2) There is no mechanism for ensuring such a chronology or if public viewings would be available.

McInnis, interview, May 5, 2000.

Bloom, interview, March 3, 2000
} 
of me to tell you what to do." ${ }^{\text {49 }}$ And, of course, with such support and confidence, the AMRF team went out of its way to help the Navy. Nanzetta fostered and nurtured this relationship, ultimately giving him power over distribution of Navy funding despite not having any designated managerial authority. ${ }^{50}$

\section{3 magic and miracles}

As the pieces and people fit into place, Nanzetta set an ambitious schedule. With only the Horizontal and Turning Workstations set up on the shop floor and a robot cart buzzing between them and material handling, Nanzetta decided that November 1983 would be a good time to demonstrate to the world the capabilities and promise of the

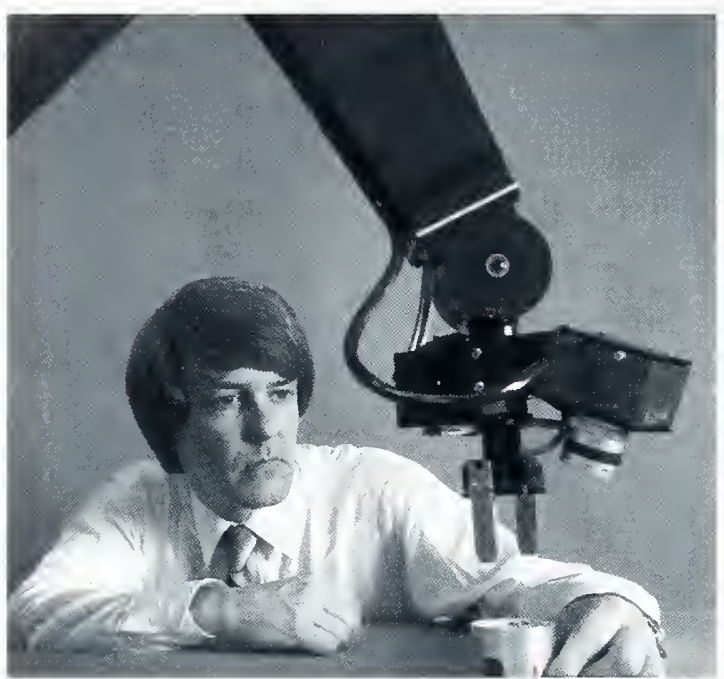

Figure 12. James Albus pioneered the idea of structured light for guiding a robot vision system. (Photo collection, ISD, NIST) AMRF. This first real deadline set in motion a frenzied flurry of activity as each group struggled to complete its research tasks. The stories surrounding the 1983 demo have become legendary amongst the players. Magic and miracles still abound.

For someone like Tom Wheatley, his deadlines were at least six months before the rest of the team. An electrical engineer, he focused on the low-level hardware and software, particularly relating to the Horizontal Workstation and its robot vision system. Wheatley worked on the processors to make sure they talked to each other and didn't get confused when they traded data. For the vision system, he checked the flash systems and camera data, ensuring that they went where he needed them to go within the workstation control system. The vision system itself had been the brain child of Albus (Fig. 12), who came up with the idea of using structured light to determine the position and orientation of an object. Albus's idea was then implemented by Ernest Kent. Kent had a Ph.D. in neurophysiology and psychology, had taught at the University of Illinois at Chicago, and had written a book on using studies in natural nervous systems to guide the design of artificial systems. Albus read the book and invited Kent to NBS in 1980 to head the machine vision project.

Within a year of his arrival, Kent had an experimental vision system hooked up to the end of the T3 robot. A strobe light just below the robot's "wrist" would flash a narrow plane of light on a randomly placed object. A solid state camera mounted at a slight angle above the robot's wrist would then register the shape of the line, whether a "v" shape for a cubicle box or a gentle curve for a cylinder. This information would then be fed into an internal database where the observed features would be compared to CAD part descriptions, allowing the computer to determine the shape of the given object. By using triangulation, the location of the apparent line of light in the camera's field of vision would give the distance between robot gripper and object. So far as Simpson and other AMRFers knew, Kent's robotic vision system (Fig. 13) in 1981 was the only one in the world that could do these tasks. Over the next two years, Kent pushed further into the unknown. Using the structured light, he gave the vision system the ability to discover surface orientations and other three-dimensional features beyond the object's

${ }^{49}$ McInnis, as quoted in Ibid.

${ }^{50}$ Nanzetta, interview, February 20, 2000; Bloom, interview, March 3, 2000.

'Wheatley, interview, May 26, 2000, Albus, Brains, Bebavior, and Robotics, 257; Ernest Kent, interview by author, April 28, 2000, audiotape, NIST. 
silhouette. Using the Real-time Control System, also developed in Albus's division by Anthony Barbera and Mary Lynn Fitzgerald, the vision system would have the necessary computing power and speed to position the robot gripper and pick up the object. One of the only things that stopped the vision system from working perfectly was competing afternoon sunlight streaming in from the overhead shop windows. To address this problem, NBS had the windows blackened with paint. ${ }^{52}$ In the meantime, researchers had designed a robot gripper, equipped with position and force sensors and pneumatic actuation (Fig. 14). This feature-laden gripper made it possible for the robot to adjust the gripper based on the size of the parts it needed to hold and the types of tools it needed to load onto the machine tool. The Horizontal Workstation also had two palettes to hold blanks waiting for machining. The robot would be kept busy placing a blank in one palette, ready for when the machine tool finished its current work with the other palette. This set-up reduced the amount of downtime for expensive machinery, a requirement for automation. This overall workstation performed in the 1983 demonstration. ${ }^{53}$

The Turning Workstation, under the guidance of Kang Lee, had its own set of puzzles to solve. Its Bendix robot proved a dinosaur within three months of delivery thanks to Bendix exiting its robot manufacturing

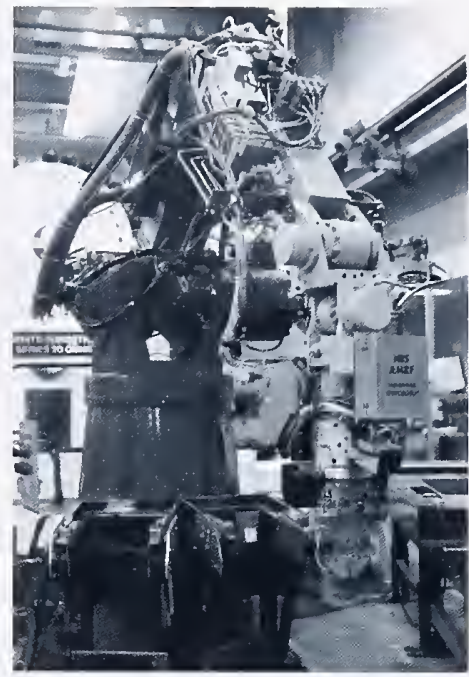

Figure 13. In 1981, the Horizontal Workstation's robot vision system, developed by Ernest Kent based on James Albus's structured light ideas, was the only system in the world at the time that could determine the shape of a randomly placed object and its distance from the robot gripper. (Photo collection, ISD, NIST) business and laying off key engineers. This situation left NBS scrambling to adapt the robot controller to the rest of the workstation. Hardinge's original Turning Workstation donation to the project also added unexpected problems. Alkan Donmez had come to NBS in 1982 under Bob Hocken's invitation to complete his Ph.D. research in error modeling and compensation using AMRF equipment. After a year of taking measurements on the Hardinge machine tool, Donmez determined that the machine had inherent design flaws causing non-repeatable errors. Hardinge immediately donated a second machine. ${ }^{54}$

By the time of the 1983 demonstration, NBS had flipped the Bendix robot upside down and mounted it on a gantry to increase accessibility to the Turning Workstation and use the short 24-inch reach of the robot in the most efficient manner possible (Fig. 15). This arrangement introduced fixturing and positioning challenges. But, the team did overcome these many difficulties and demonstrated the robot loading blanks into the original Turning Workstation, which then cut small cylindrical metal screw-topped containers used by NBS for packaging and shipping samples. Alexander Slocum and Peter Jurgens, under group leader Don Blomquist, had also designed a robot gripper for the Bendix with a holding force of 1,000 pounds and different "fingers" for loading parts and changing tools. One set of narrow fingers allowed the robot to position parts into the machine tool collet, which had a small clearance, without having to set the part down for re-positioning. Another set of wider

\footnotetext{
${ }^{52}$ Wheatley, personal communication, January 3, 2001.

${ }_{35}$ John A. Simpson, "Automation Research at NBS: Seeking Generic Technology for the Automated Shop," NBS Dimensions 65 (May/June 1981): 4; Behr, "Even in R\&D, Standards Bureau Measuring Up," 1, 7; Nanzetta, "Update: NBS Research Facility," 71; Kent, interview, April 28, 2000; Rippey, interview, March 10, 2000; Ernest Kent, "The NBS Robot Vision System," November 1983, and Harry G. McCain, "Instrumented Gripper," October 1983, both in "Briefing Notes on AMRF November Run for CME Planning Council Members," File Demo November 1983, AMRF Files, NIST.

Gerry Khermouch, "Automated Workstation Interests Navy," American Metal Market/Metalworking News (December 22, 1986), 8; Lee, interview, April 7, 2000; Donmez, interview, May 12, 2000; "Computers with Muscle: A Fully Automated, Flexible Machine Shop," Computers in Mechanical Engineering (January 1984): 4; D. S. Blomquist, "Turning Center;" D. S. Blomquist, Turning Center Robot;" D. S. Blomquist, "NBS Turning Center Gripper," all October 1983, in "Briefing Notes on AMRF November Run."
} 


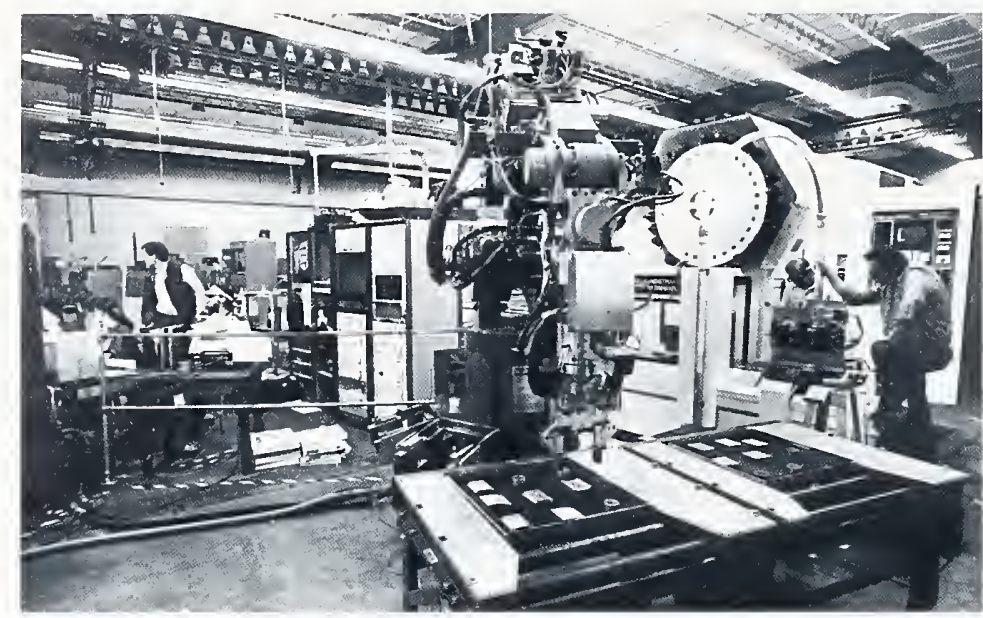

Figure 14. The T3 robot's feature-laden gripper could adjust based on the size of parts it needed to hold and the types of tools it needed to load onto the Horizontal Workstation's machine tool. (Photo collection, MB-1, ISD, NIST)

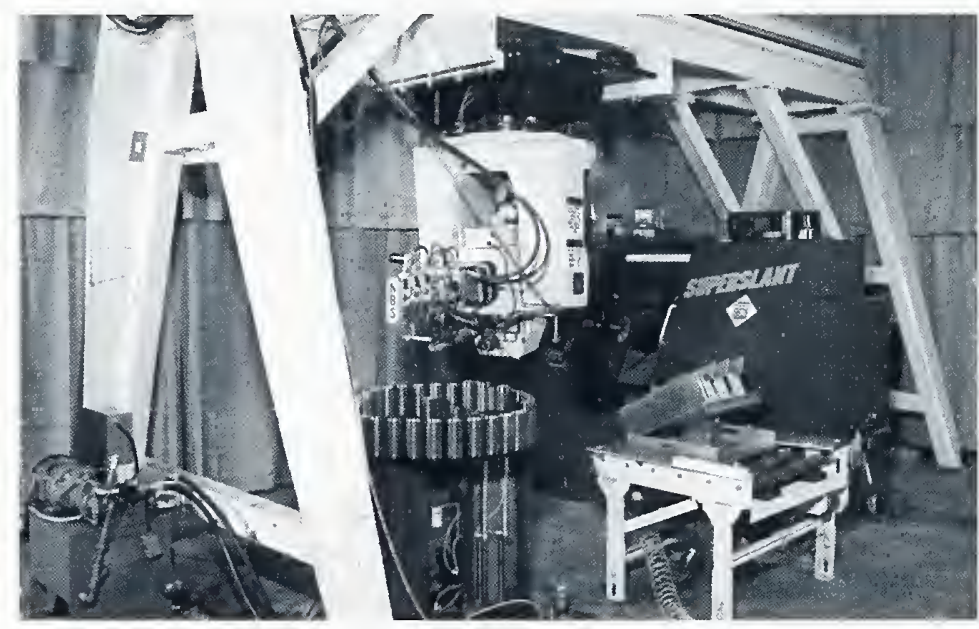

Figure 15. The Turning Workstation's Bendix robot with NBS-developed micromanipulator handled metal blanks which the machine tool cut into small cylindrical Standard Reference Material containers for the Bureau. (Photo collection, AMRF Files, NIST) fingers reduced rotation of parts as they were loaded into the collet. And, a double-ended gripper design increased productivity by allowing insertion of a blank while a finished part was loaded onto the parts tray.

Between the Turning and Horizontal Workstations and the Material Handling System buzzed a robot cart. Cita Furlani and Steve Schrantz designed this material handling workstation controller while Harry McCain, Maris Juberts, Sandor Szabo, and Mitch Tarica focused on the actual cart. Built by Control Engineering Corporation, the robot cart could carry a load of heavy cast aluminum blocks to the Horizontal Workstation, for example, and wait until the $\mathrm{T} 3$ robot lifted them onto its own work table. Once the Horizontal Workstation had finished machining the blanks, the cart would return to pick up the tray of finished parts, take them to storage, and provide the Horizontal Workstation with a new set of blanks. Magnets embedded into the shop floor at each expected cart stopping point gave unique addresses which

the cart read when passing over them. An Intel 8086 microprocessor system in the cart allowed it to be interfaced into the NBS Hierarchical Control System (HCS) to receive commands from the next higher level and report status. To test these operations without always running the actual robot cart, Furlani and Schrantz used the newly developed Hierarchical Control System Emulator (HCSE). The emulator, actually a collection of computer programs written in the high-level language of PRAXIS using state tables, ran on the new 2-room size Digital Equipment Corporation VAX computer dedicated to the AMRF project. Used as the major control element in the 1983 demonstration, the emulator made it possible to match the different workstations together and run them as a coherent system.

"Blomquist, "Turning Center," Blomquist, Turning Center Robot;" Blomquist, "NBS Turning Center Gripper," all October 1983 in "Briefing Notes on AMRF November Run.

${ }^{36}$ Cita M. Furlani, "Material Handling Workstation Controller," Cita M. Furlani, "Hierarchical Control System Emulator," and Harry G. McCain, "Robot Cart," all October 1983, in "Briefing Notes on AMRF November Run;" "Computers with Muscle," 4; Furlani, Kent, Bloom, and Mclean, "The AMRF of 
O MAKE A TRULY AUTOMATED FACTORY required integration, the next big step in readying for the 1983 demonstration. Here, Nanzetta's forced deadline on the scientists and engineers proved essential for driving the project forward. Within the individual workstations, integration meant coordinating the robot, gripper, sensor systems, and machine tool in the common task of machining a blank. The Horizontal Workstation also had a watchdog safety system, designed by Roger Kilmer, to keep track of the 1.5-ton robot swinging arm, keeping it from crashing into people and equipment and from destroying the precious robot vision system delicately attached to its wrist. Howard Bloom's group took over the next stage of integration and worked on having each workstation communicate with the others and the cell control system, the highest level of Albus's hierarchy achieved for this demonstration. ${ }^{57}$

This integration work involved first developing protocols with neutral interfaces so that the Horizontal Workstation could, for instance, talk to the robot cart. Second, the integration team had to develop tools for diagnosing problems and their location within this maze of independent systems. Mary Mitchell of Bloom's group remembered testing their integration strategy early on by having people sit around a room and pass pieces of paper, physically handing over ownership of a part as it moved throughout the factory. No one else anywhere was addressing such involved integration issues, so the AMRF team contributed some forward thinking that has been a foundation for ongoing work. To provide some indication of the integration challenges involved, the AMRF introduced during the 1983 demo 34 new interfaces among distinct subsystems, most of which involved two or more units made by different manufacturers. ${ }^{58}$ As one AMRF roboticist later admitted, "No company in its right mind would build a facility like the AMRF. It is designed in worst case because we're interested in dealing with interface problems" ${ }^{\prime 59}$ among as many different kinds of equipment and manufacturers as possible.

Bloom and others quickly learned that integration involved more than communication interfaces. It also meant forcing the ever-curious researchers to stop their constant tweaking of their systems. Nanzetta exercised his nominal authority as program manager and enforced a methodical approach to integration: once the tests were finished and successful, researchers were not allowed to change their systems. Research had to stop until after the demonstration. This order left many researchers unhappy because they still had interesting problems they wanted to investigate. But, that was the rule. ${ }^{60}$ As Bill Rippey from the Horizontal Workstation team remembered, things almost got personal during integration time. "Look me in the eye and tell me this is [version] one point one."61 In other words, researchers had better not try to sneak in changes after an integration test — but they still did, in sometimes memorable ways, as described later. At the same time, as Cita Furlani pointed out, integration tests proved how "really strong-willed highly capable technically oriented people can work together. There was a lot of pull and tug but the end result was well worth it." ${ }^{12}$ That end result was a functioning automated factory, the vision each and every person on the AMRF team had and worked together to achieve.

Working together meant working day in and day out as November neared. Tensions increased as systems came together but did not quite work right or sometimes even at all. Hours in the lab expanded to figure out

the NBS," 10-14: Bloom, interview, March 3, 2000. Bolt, Beranek, and Newman, Inc. originally developed the HCSE in 1982. Tim Johnson, Cita Furlani, and others extensively modified it for use in the AMRF.

"7 Harry G. McCain, "Integrated Robot System;" Roger D. Kilmer, "Watch Dog Safety Computer;" and Al Jones and Charles McLean, "Cell Control System;" all October 1983, in "Briefing Notes on AMRF November Run."

Bloom, interview, March 3, 2000; Mary Mitchell, interview by author, May 5, 2000, audiotape, NIST; Michael Baum, "Fact Sheet: Automated Manufacturing Research Facility (AMRF)," Novernber 1983, File Original Fact Sheet, AMRF Files, NIST.

i9 Kenneth Goodwin, quoted in Pellerin, "Scientists Help," 15.

50 Bloom, interview, March 3, 2000; Mitchell, interview, May 5, 2000; Cita Furlani, interview, March 24, 2000.

Rippey, interview, March 10, 2000.

Fin Furlani, interview, March 24, 2000. 
problems. Harry Scott proudly recalled that his team members on the Horizontal Workstation were "young energetic people that only marginally objected to being there until $3 \mathrm{AM}$ in support of those demos." ${ }^{\text {"63 }}$ The unexpected always seemed to happen. Roger Kilmer, who was working on the Horizontal Workstation's watchdog safety system, recalled Bill Rippey teasing his fellow teammates. They were still fixing glitches in their systems while Rippey described himself set to go, "bullet proof." "I swear the words 'bullet proof' were still echoing in the Shops," Kilmer later said, "as there was kind of a loud pop, out of the corner of our eyes we could see a spark or flame and then smoke as his system . . . proceeded to have a small catastrophe and he burned up a board, ... he suddenly was in panic mode to get his system back together and working. ${ }^{, 64}$ Scientists and engineers, technicians and managers saw the best and worst in people under such conditions, and many close and lasting friendships resulted. Tony Barbera, who was well known for spending days at a time in the lab, remembered the talking and sharing beyond the technical stuff they were addressing. "Interesting discussions you get into at two in the morning standing out on the shop floor trying to get something to work. You see the world in a totally different light at that time."

TAKES ROSE as the news came down that Secretary of Commerce Malcolm Baldrige would be the first person to push the button and make the AMRF dance. People realized that this November 1983 showing wasn't just any old demonstration. It was the defining moment. They had to pull it off. Or potentially see the project canned and their jobs lost. The AMRF, with its large number of employees, cooperation of several divisions, and coordination of a dozen company research associates and six universities, had become a project beyond anything ever seen at the National Bureau of Standards. ${ }^{66}$ And they had to show their stuff to survive. Unfortunately, what made the AMRF so revolutionary- the tying together of disparate equipment and making it work together as an automated factory - was the very thing that made it so fragile. "No one really knew if this was going to work," remarked Al Jones about the 1983 demo. "Right up to the very day that this thing was supposed to happen, it didn't work together. There were parts of it that worked, but the whole thing didn't work. There was a lot of anxiety about the event." ${ }^{, 67}$ The upper echelons of the Bureau felt that anxiety keenly. CME director Simpson told his crew, "Don't tell me anything that might complicate my life." So, his division chiefs would report that things were going great. ${ }^{68}$ But people knew otherwise. National Engineering Laboratory director John Lyons had his doubts about whether the AMRF would work. So did NBS Director Ambler. ${ }^{69}$

For Ambler, the nuclear and cryogenic physicist whose research days had been spent more with slide rules than computers, the industrial factory run by computers and based on new advanced ideas in artificial intelligence such as those propounded by Albus and others was so foreign from his sense of the traditional role of the agency and his own technical experience. Ambler has been credited with saying once, "So and so loves the AMRF, so and so loves the AMRF, so and so loves the AMRF, why don't $I$ love the AMRF????"70 He supported it and knew it was important. But he also would pull the plug if the project ended up becoming an embarrassment. To

\footnotetext{
${ }^{63}$ Scott, interview, June $16,2000$.

${ }^{64}$ Kilmer, interview, July 28, 2000.

${ }^{65}$ Barbera, interview, May 22, 2000.

${ }^{66}$ Baum, "Fact Sheet: AMRE."

Al Jones, interview by author, May 19, 2000, audiotape, NIST.

${ }^{68}$ Simpson, as quoted by Bloom, interview, March 3, 2000

${ }^{69}$ Bloom, interview, March 3, 2000.

${ }^{70}$ Ambler, as quoted by Bloom, interview March 3, 2000.
} 
make certain Simpson understood the importance of the demonstration and that failure meant that "we would all be in the soup," Ambler called his senior technical aide, Dennis Swyt, to his office and directed him to convey a message exactly. Swyt, who had been present during Russ Young's group leader's meeting where some of the initial ideas for the AMRF formed, recalled the incident with Ambler well.

He told me to tell John Simpson that "When I, Ernie Ambler, bring the Secretary of Commerce down to the AMRF and when the Secretary of Commerce pressed the button to start the operation of the AMRF, the [expletive deleted] had better work." I conveyed the message to John Simpson exactly, and he seemed to appreciate its significance. ${ }^{72}$

And so it came to the night before the November 14, 1983 demonstration.

Bloom had considered it his job to bring food every night, to keep the researchers in the lab. If they went out to fill their stomachs, they might not come back. And he needed them. Integration testing kept failing, and they had to figure out where the problems were. But, at around midnight the night before the big show, as Bloom remembered, they had their first fairly successful integration EVER. Then, a guard walked by with his ticket book and asked whose car was parked at the Shops loading dock. It was Harry McCain's. The guard asked him to move it or get a ticket. McCain replied, "You gotta be crazy. It's two o'clock in the morning, who's going to be here at two o'clock in the morning?" The guard was insistent, Harry refused to move his car, and the guard gave him a ticket. After the demo, Simpson went to Lyons who went to the Director of Administration and took care of the ticket and the guard. ${ }^{73}$

Silly stories like these helped relieve some tension, but a potentially fatal bug kept itching the Horizontal Workstation team. One problem with the software created a damaging system crash at unexpected times. They did not want such a crash to happen for the Secretary of Commerce, so they wracked their brains all night and into the wee hours of the morning. At around six in the morning the day of the demonstration, they came up with a fix. Baldrige was due in less than four hours. Barbera remembered telling Nanzetta he had a fix, and Nanzetta, invoked the rule of no changes after successful integration, saying, "No way are you touching any software. This is not going to happen. We'll take the risk. You're not going to touch any software." " But Barbera and team were convinced they had the solution. "So we were on walkie talkies at the time. . . . We were sort of talking in code through the walkie talkies as we were doing the software patch. We were loading the code as Malcolm Baldrige was walking down the hallway for the demonstration, and it worked. I don't think Phil [Nanzetta] knows to this day that we actually ended up doing all of that recompile., ${ }^{75}$ Now he does. ${ }^{76}$

At ten o'clock on November 14, Secretary of Commerce Baldrige finally sat down at the cell control station computer next to software engineer Chuck McLean, who had been in charge of designing the cell control system. McLean explained that the Secretary could choose a part to be made from four types, press the button, and watch it being machined. As the highest level of the hierarchy implemented, the cell control would sequence through all the jobs that the workstations could do and issue commands based on the part order selected. Such a capability,

\footnotetext{
Emest Ambler, personal communication to author, December 4, 2000, File Ernest Ambler, AMRF Files, NIST.

Swyt, interview, March 10, 2000.

McCain story as quoted by Bloom, interview, March 3, 2000.

Nanzetta, as quoted by Barbera, interview, May 22, 2000.

Barbera, interview, May 22, 2000.

${ }^{16}$ Navy ManTech director Jack Mclnnis put some perspective on such last-minute changes. He had the comfortable job of being a mere observer during these demonstrations. " $1 \mathrm{knew}$ that sometimes they would be there at 90 ' clock in the morning putting the finishing touches on a controller program as we were being ushered in. You would expect that, it was a living breathing place." Mcinnis, interview, May 5, 2000.
} 
manufacturing driven by part geometry, was a hallmark of the AMRF. Unlike many other folks the night before, McLean had had some time free, and he entered into the cell control the ability to hold an additional 25 part orders. If more orders were entered, the system would gracefully reject them. McLean's act proved fortuitous. That morning, Secretary Baldrige selected a part, pushed the button, and then held it down. With the VAX computer, holding down a key meant repeating the order. As McLean recalled, "Baldrige sits there and looks at me and says, 'Am I doing this right?' and he's holding down this key like this, and I'm looking at all these things entering and going by on the screen." "He entered maybe 32 jobs, a number greater than what the system could have handled if McLean hadn't worked on it the night previous. Bloom later related the possible severe consequences. If McLean hadn't changed it, "the operating system would have given back a table overflow error, nothing would have worked. It would have been an hour maybe to fix this thing. We would have been dead meat."

OW CAME THE MOMENT OF TRUTH. Would the robot cart appear and transport the first blank to the Horizontal Workstation? Initially hidden behind the material handling storage system, the robot cart moved at the snail's pace of two miles per hour. They all held their breath. And then, finally, they saw the cart come around the bend (Fig. 16). There was such relief. They had won that high stakes poker game. Bloom remembered fondly that "for that day, pretty much the system worked. . . . That was the day it had to work. It got a great write-up in the paper, our program was saved." AMRFers referred to it as their "miracle story." Again, Bloom recalled that "we all thought that was a miracle, that was God looking down on us and feeling sorry for us. And we talked about that as a miracle." With magic and miracles, Secretary Baldrige received a dovetail box with the letters "AMRF" etched on top, and the project had its life extended for another dozen years.

Two days later, on press day, events turned toward the fantastic. The Potomac Electric Power Company (PEPCO) had taken one of two NBS power stations out of commission for the day to do work. A squirrel incinerated itself in the second transformer and glitched the power. At that very moment, the $\mathrm{T} 3$ robot was conducting a task. The robot did not have absolute positioning so its controller lost track of the robot and responded by shutting itself down. The hydraulics started draining out of the robot arm, which weighed a ton and a half and had about a million dollars' worth of instrumentation, including Ernie Kent's world-class vision system, on its end. The robot arm happened to be below the position of the safety shot pin point, so very slowly, the arm began to settle toward the concrete shop floor. ${ }^{82}$ Tom Wheatley recalled, "That's where just sheer luck, hours and nights of training [paid off]. If we had actually anticipated [such an event] and tried to do it, we would have fouled up big time. It just happened. So that we instantly split off into whatever groups were necessary. ${ }^{, 83}$ Wheatley climbed up the robot. Roger Kilmer and two others grabbed the overhead crane and tried to fit slings under the robot arm, with Wheatley's help, to hold it up. Kent could see they weren't going to make it.

\footnotetext{
${ }^{7}$ McLean, interview, June 2, 2000; Bloom, interview, March 3, 2000.

Bloom, interview, March 3, 2000. See also Nanzetta, interview, February 20, 2000.

Ibid. See also Mitchell, interview, May 5, 2000.

${ }^{\infty}$ Bloom, interview, March 3, 2000.

"Computers with Muscle," 4; US Department of Commerce, News Release, "Baldrige Notes Industry-Govt. Cooperation in Automation Research at New Bureau of Standards Facility," November 14, 1983, File Demo November 83, AMRF Files, NIST; Albus used the poker metaphor. See Albus, interview, February 25, 2000.

${ }^{82}$ Kent, interview, April 28, 2000 .

${ }^{33}$ Wheatley, interview, May 26, 2000.
} 


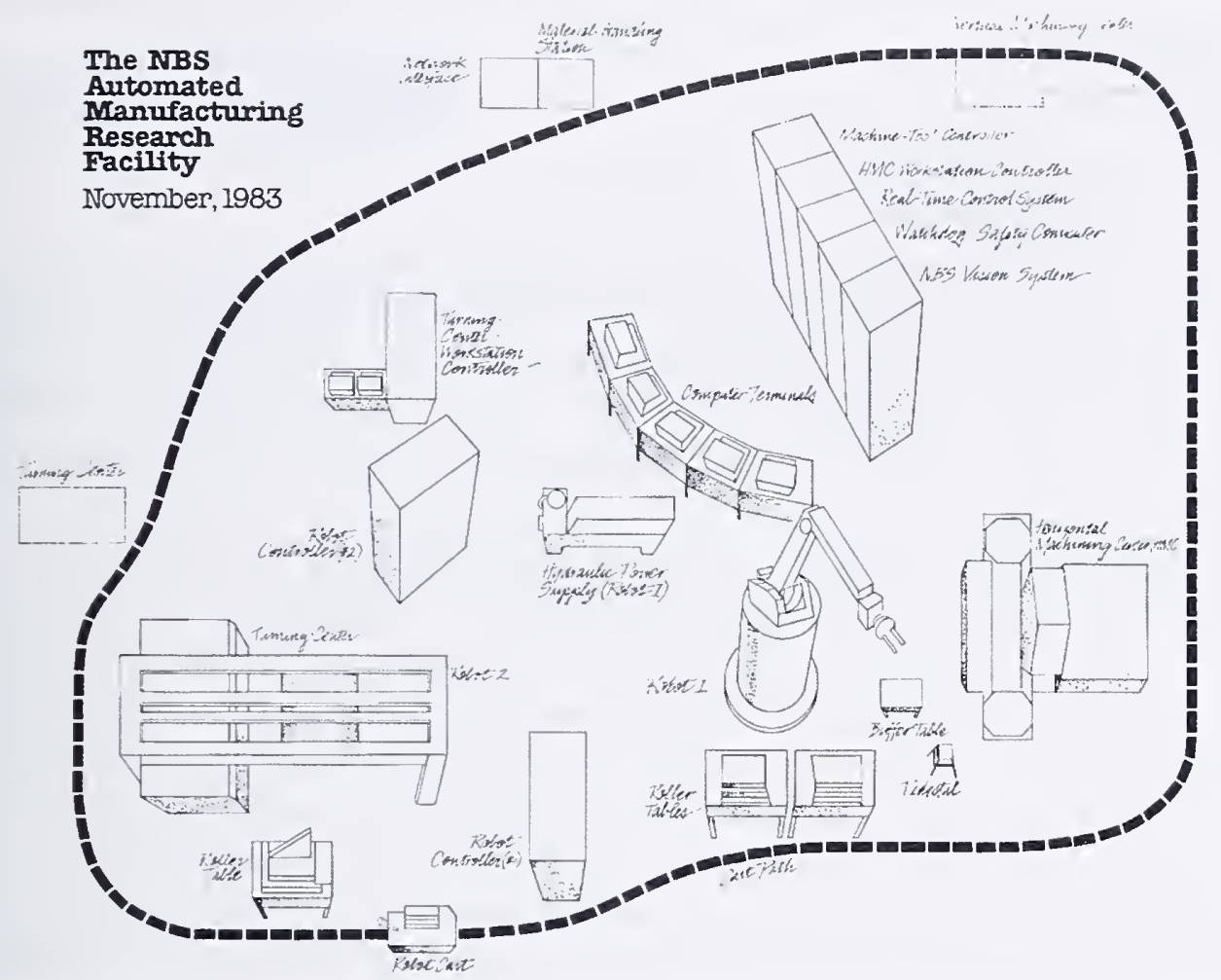

Figure 16. For the 1983 first full demonstration of the AMRF, a robot cart and Material Handling System connected the workstations along an oval path. (AMRF Files, NIST)

I wasn't about to have my camera smashed, so I got down on the floor under this robot arm as it was coming down and started piling up some metal brick that we had under the table, trying to maneuver it so that it just caught on the edge of a good solid piece of the end effector, and it would take the weight instead of coming down to the floor on the camera. To do this, of course, I was down on my hands and knees under this thing, with my rear end aimed nicely at the photographers who were all flashing away. The only thing that made the newspapers that day was this picture of my rear end with headline: "NBS Scientist Saves Robot!" ${ }^{\prime 4}$

Kent's posterior was joined in some papers by a view of the group with the overhead crane. Kilmer later admitted that it looked like a perfect re-creation of the Iwo Jima Memorial. "Here was our first experience bringing the public in and running automated equipment and here we are strapping it up to keep it from destroying itself." ${ }^{85}$ The miracle of saving the robot arm and its equipment was matched by the miracle of recovering from the shutdown. The AMRF team had been dealing with so many crashes over the course of the previous months that they had established a standard protocol for bringing the system back up. The members of the press were as impressed by Kent's heroics to save the vision system as they were by the fact that the researchers

\footnotetext{
${ }^{84}$ Kent, interview, April 28, 2000.

${ }^{85}$ Kilmer, interview, July $28,2000$.
} 
had the system up and dancing within thirty minutes. Plus, lots of smooth talking, what Bloom considered a requirement for being an AMRF manager, kept the pace moving without alarming visitors. ${ }^{86}$

Looking back on that first demonstration, at least a couple of researchers have since admitted to the use of some smoke and mirrors to succeed. Ed Barkmeyer, who was in charge of networking before he moved on to the distributed database work, recalled that they faked about half of the original software system design. Nanzetta would not let this go, so with the new year, he put on the pressure. He would not give up until the system really worked. On March 12, 1984, Barkmeyer and gang ran the system and it crashed right around dinnertime. After a break, about twelve survivors returned and fired the system up again. Magic resulted. The facility actually worked and made one each of eight different parts. "Just as we were starting the shutdown sequence," added Barkmeyer, "the robot vehicle that was delivering parts, was taking away the last set of parts when its battery went dead. We called it a success and walked away.",

The Shops people certainly had the last laugh after viewing all of the heroic efforts to run the first demonstration of the automated manufacturing facility. Russell Young, back in 1976, had written to NBS management that more attention had to be paid to the impact of automation on labor. Society could not assume that the transition would be welcomed or easy. ${ }^{88}$ Such a point was literally magnified in a television interview for a local Washington, DC station. Early in the project, news reporter David Schumacher toured the AMRF. A bunch of people, including Howard Bloom and Ted Hopp, the latter hired in 1981 to work on the automated inspection machine, sat around a table and discussed the promise of automation, having machines do the work. But, when the piece aired, Schumacher showed a tape of dedicated machinists in a shop with Hopp's voice saying "We'll be better off, there is no question about it, if for instance, all the factories were automated, and you didn't need anybody" over and over again. Hopp later said, "It was an awful experience, it's not at all what I thought about things. We didn't think we were putting people out of work. We thought we were working to preserve the strength of American industry against foreign competition." ${ }^{89}$ Any suspicions within the Bureau of Standards evaporated after the squirrel incident. Cita Furlani noted that "once the machinists in our Shops saw how many of us were on the Shops floor, they realized that there was no way we were getting rid of the people in the factory. They relaxed quite a bit." ${ }^{\text {"9 }}$ Bill Rippey laughed when saying, after the squirrel fiasco, the Shops people looked over and said "My job is safe, even my kid's job is safe." ${ }^{.91}$ For the time being, the AMRF continued to set its sights for total factory automation. But, the events of the first demonstration foretold that changes would come as the rewards and costs of automation unfolded.

\footnotetext{
${ }^{86}$ Bloom, interview, March 3, 2000.

Barkmeyer, interview, June 9, 2000. Bob Lach also referred to the smoke and mirrors or sleight of hand involved in some of the early demos. See Lach, interview, July 21, 2000.

${ }_{88}$ Russell D. Young to Assistant Secretary Ancker-Johnson, October 18, 1976, Comments on CIRP member attitudes toward impact of automation on workers, File Russell Young, AMRF Files, NIST.

${ }^{89}$ Hopp, interview, June 30, 2000. See also McLean, interview, June 2, 2000 and Bloom, interview, March 3, 2000.

${ }^{90}$ Furlani, interview, March 24, 2000.

91 Rippey, interview, March 10, 2000.
} 


\section{Chapter Four}

\section{GRADUATION}

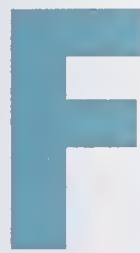

LUSH FROM THE MAGICAL DEMONSTRATION of 1983, the AMRF team expanded its horizons. Additional workstations joined the Horizontal and Turning Workstations in week-long performances. Photography sessions, videos, and weekly Thursday demonstrations kept the facility in the public eye. Robots danced and machine tools whirled under the control of an innovative distributed database. ${ }^{1}$ Researchers applied their expertise to real-world situations for the United States Navy and extended the utility and promise of the automation. Cooperation with industry and academia brought new ideas and experiences to meet the continuing challenges of a lights-out factory. The 1986 full facility graduation came with some unexpected results, including the exodus of some important people, shifts in research emphases, and, two years later, a change in mission and name for the Bureau.

More and more company representatives wanted to see the facility for themselves and judge its application to their own businesses. To accommodate this surge in interest, AMRF program manager Phil Nanzetta instituted one-day industry briefings every two months. When these briefings could not handle the level of interest, Nanzetta made every Thursday afternoon a show-and-tell time. Still more people came. Nanzetta recalled, "We were being pounded to death by visitors who wanted to come through the facility to such an extent that the number of visitors was seriously interfering with the technical work." ${ }^{2}$ Yet, he could not refuse them, so Nanzetta decided to use videotapes and a non-critical technical person to take visitors down the Shops hallway to look at the robots and machine tools, without disrupting the research work. ${ }^{3}$

Nanzetta and the Bureau of Standards also encouraged companies to send researchers for six months to a year to explore questions of common interest to both the government and industry. By October 1984, 34 such industrial researchers had taken advantage of this offer. A change in approach also allowed some proprietary work to be done in NBS labs, making the AMRF and its research environment even more attractive. Companies could engage in company-specific work at the NBS facility but share non-proprietary research results. Boeing brought in several research teams between 1984 and 1986 to study how Albus's advanced factory control system could be applied to Boeing's own manufacturing operations. And, firms posted results soon after their researchers returned. Experience with the Turning Workstation convinced Brown \& Sharpe machine tool company to offer linear and axial correction in one of its products. The company also decided to focus its development work for the next three to four years on in-process metrological equipment. Some research projects also brought immediate financial benefits. Optical Electronics Corporation showed perhaps the most impressive gains. After adopting error maps and real-time sensor-driven correction to correct for tool wear, vibration, and barometric pressure, this

The distributed database was recognized for several innovative features by a Massachusetts Institute of Technology-sponsored comparison of thencurrent distributed database research programs. See Mitchell, interview, May 5, 2000.

Nanzetta, interview, February 20, 2000.

Nanzetta, interview, February 20, 2000; United States General Accounting Office, Opportunities and Constraints for Expanding Use of Research Facilities at the National Bureau of Standards, GA0/RCED-85-55 (Washington, DC: GP0, 1985), Appendix IV, 35; Nanzetta, "Update: NBS Research Facility Addresses Problems," 73. These AMRF-wide videotapes were produced in January 1984, October 1986, March 1987, and November 1991. NBS also completed individual videotapes for the three main workstations. These tapes are available in the AMRF Files, NIST. 
company reduced unit costs from $\$ 40,000$ to $\$ 200$ and increased production from 2 per year to the amazing rate of 10 per day.

Despite such documented examples of industry interest and pay-off, the Reagan White House continuously expressed its disapproval of the AMRF project. In 1984, the President withheld approval of the entire NBS authorization to voice his administration's displeasure with the AMRF, stating that the project represented an "unwarranted role for the federal government. ... The decisions on how to allocate investments for research on manufacturing technologies are best left to American industry." Congress rescued NBS in that case, but such antagonism continued. The President's Science Advisor threatened to shut down the facility if it was the last thing he ever did. ${ }^{6}$ Ambler also recalled seeing the same person at an evening reception and tried to engage him in conversation about the status of US manufacturing in comparison to Japan. Ambler remembered being curtly rebuffed with the remark, "Ernie, I don't want you lecturing me about Japan."7 Fortunately, the AMRF had its own influential supporters. Ray Kammer, who worked under Director Ambler as the NBS Associate Director for Programs and Finance and then as deputy director, sold the AMRF on Capitol Hill. He articulated the importance of the automation project in ways that members of Congress could comprehend. "At some level, everyone can understand cutting metal. ... The tolerances were getting tighter and tighter and that was intuitive to most people. It made sense to most people. . ." ${ }^{8}$ He was also not hung up by the technicalities of the research. In comparison to Director Ambler, the physicist, Kammer admitted that, "as an English major, I didn't know too much. What [Ambler] might have thought was a painful oversimplification I was perfectly content to say." Secretary of Commerce Malcolm Baldrige joined Kammer in ensuring the survival of the AMRF. Baldrige had personal experience in the world of manufacturing, and his name would be used, as a memorial to him after his fatal accident, for the most prestigious award in manufacturing excellence. ${ }^{10}$ Baldrige knew the AMRF served a real need in American industry and fought to keep it alive.

HIS CONSTANT STRUGGLE FOR MONEY had its consequences. As Howard Bloom later articulated, "It was very nerve-wracking for us as government employees because what do we do?", The expectation of job security would be questioned with every budget cycle. As industry displayed its endorsement through record attendances at demonstrations and increased sponsorship of research associates, the federal government frustrated the Bureau of Standards with its continued lukewarm support. National Engineering Laboratory director John Lyons admitted that "there was a lot of intellectual support but there was never the kind of financial support that it should have had, in my opinion, and looking back it's really disgraceful." ${ }^{12}$ The Navy's multi-year commitment served as a life line, keeping the project afloat as people like Kammer and Baldrige wrestled with Congress for the rest of the funding. Congress did recognize the importance of the AMRF and all of the work within the National Bureau of Standards, protecting the agency as

\footnotetext{
NBS, Annual Report, July 1984, foreword, NIST Library; Computer Age (November 5, 1984), Black Binder News Releases 12/82-6/85, AMRF Files, NIST: Baum, "Standard Interfaces Key to Factory Automation," 6; Meade, The NBS'AMRF, 46-47.

Reagan Office of the Press Secretary, as quoted by Hocken, interview, March 3, 2000.

Simpson, 1993, transcript.

Ambler, personal communication, December 4, 2000.

Kammer, interview, June 16, 2000

lbid.

The Malcolm Baldrige National Quality Award, as established in Public Law 100-107, signed in August 1987.

Bloom, interview, March 3, 2000.

Lyons, interview, July $28,2000$.
} 
best it could from the most severe federal government budget cutting characteristic of the Reagan period. In the end, around 40 percent of AMRF funding came from outside sources. The Air Force, NASA, and others sponsored their own smaller research projects in the facility. But, the Navy money proved the essential source. Lyons described the Navy as "a very strong and loyal supporter.",

ROM THE NAVY'S PERSPECTIVE, the AMRF fit its needs well. Navy ManTech director Jack McInnis noted that although the AMRF researchers "sounded like academics sometimes, ... [their] time scale was always real world, there were no five-year development programs up there. They could move very quickly and get you an answer very fast." ${ }^{14}$ One favorite example dates from around 1986 when many battleships were taken out of mothballs. The USS New Jersey had a broken oil flinger, a several foot-long oddly shaped geometric part that kept the ship's gears bathed in oil, preventing them from wearing out. ${ }^{15}$ The part probably dated from 1939, and the drawings were long gone. McInnis presented the part to the AMRFers, asking for help so that the ship could go out to sea. After laser scanning the piece and doing a metallography, which showed a metal no longer available, the AMRF researchers generated a cutter location program and built a new part using material stronger than the original. And, they did it in about three weeks. "There are dozens of little stories like that," McInnis recalled, "where they saved our bacon on programs. It was a helluva good capability, at the eleventh hour, when you gotta have it, they always came through for us." ${ }^{, 16}$ Giving the long view, McInnis's replacement Steve Linder later stated that it continues to be "very important to the economic security of the US that we fund these types of programs. It keeps the nation strong in terms of having an industrial base that can support defense needs and commercial needs.",

\section{Enhancing the dance}

With such a commitment from industry, the Navy, and the Congress, AMRF researchers had the environment to expand the capabilities of their automated facility and make more robots and machine tools dance in dazzling combinations. Center for Manufacturing Engineering Director John Simpson remained open and accepting to the new challenges of the facility. One key area to which he lent his support was software. He understood early on the significance of coding to the success of the facility. "We now believe," Simpson was once quoted as saying, "that the factory of the future will look like the computer installation of today, except that the 'peripherals' will have muscles. Instead of printers and plotters you will have lathes, milling machines, and robots." ${ }^{\text {,18 }}$ one reporter echoed this statement, noting that the AMRF shop floor was "unusually quiet for a machine shop: the machinery is rarely switched on. All the real work goes on at the computer terminals scattered between the metal crunchers." 19

Sitting at those terminals were a host of electrical engineers, mechanical engineers, software engineers, and others who relied on regular meetings and opportunities for communication to make sure their individual systems integrated with the overall facility. While each used James Albus's overall hierarchical control structure as

\footnotetext{
Ibid.

${ }^{14}$ McInnis, interview, May 5, 2000

'Philip Nanzetta to Loma B. Estep, July 28, 1986, and attached Supplementary Report on RAMP Program Tasking for FY 1986, 6, File QRT Report/July

86, AMRF Files, NIST; McInnis, interview, May 5, 2000.

${ }^{16}$ Mclnnis, interview, May 5, 2000 .

Steve Linder, interview by author, June 23, 2000, audiotape, NIST.

${ }^{18}$ Simpson, as quoted by Baum, "Standard Interfaces," 6.

ig Joyce, "Factories Will Measure as They Make," 47.
} 
a model, complication came in the details. Simpson helped facilitate the necessary interaction to overcome these obstacles. Most importantly, he kept his two division chiefs, Albus and Bob Hocken, from crashing before their show hit the big stage. Clayton Teague, who had worked under Russell Young, later noted that Simpson "had the technical acumen to maintain both of their respects. John was a very strong technical person, and Hocken and Albus [were] also equally strong folks, and without someone who had the real technical acumen that Simpson had at the time, it would have been very difficult to lead two strong people like Hocken and Albus. . . . His knowledge and his ability to work with them was essential to [the AMRF's] success, there's no question." ${ }^{20}$

Simpson's efforts did not make all meetings quiet affairs of polite conversation. Such a scenario would have been anathema to the revolutionary work being accomplished within the automated research facility. But, Simpson did give the project a chance to get beyond personalities and differing technical backgrounds to address the issues at hand. Another aid in this effort came from Phil Nanzetta, who instituted in 1984 an AMRF Architecture Committee. Tasked to initiate, review, and approve architectural guidelines for the AMRF, the committee included Nanzetta, Hocken, and Albus, with Chuck McLean as the AMRF Architecture Coordinator and Tony Barbera as technical consultant. Three working groups within the committee structure explored manufacturing technology, intelligent control, and software integration, breaking down the issues and delving into them systematically. ${ }^{21}$ Despite these good intentions, frictions still sparked. Vertical Workstation team member Thomas Kramer recalled that "you would have these meetings, and you'd think that all you were discussing were a few data formats for common data, and inevitably they would break down into loud contentious arguments about various aspects of architecture. Everyone agreed that they should use hierarchical control, but details differed." 22

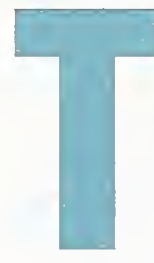

HESE ARCHITECTURE DISCUSSIONS, no matter how loud, took some pressure off the regular Thursday morning AMRF meetings. Attended by as many as 40 people, these meetings became legendary. Harry Scott, who worked on the Horizontal Workstation, remembered that the whole team would show up and discussions would heat up at times, sometimes useful, sometimes not. But, it promoted lots of interaction. ${ }^{23}$ Roger Kilmer of the Cleaning and Deburring Workstation team considered these weekly planning meetings to be "perfect examples of how not to run meetings. . . . The individual camps from each of the divisions would kind of position themselves for different pieces. ${ }^{24}$ But, Kilmer saw this as a positive in the long run because the meetings pulled the various divisions together and forced them to "work together and share ideas and do things jointly." 25 Network and database manager Ed Barkmeyer thought of the meetings as evidence of "a certain sense of responsibility without rank" within the AMRF group. When he passed Sandor Szabo in the hall one day and asked if he was going to a meeting with Nanzetta, Szabo replied that he was too junior. Barkmeyer took Szabo down and Nanzetta asked what Szabo did. Szabo replied that he was writing the code for the robot cart, and, as Barkmeyer remembered, Nanzetta replied, "You sure as hell ought to be here!"27 Barkmeyer related this event to the fact that "if this is your job, we're all participating on

\footnotetext{
${ }^{20}$ Teague, interview, July $28,2000$.

Phil Nanzetta to Participants in Thursday Morning AMRF Meetings, Re May 17 Meeting and attached Memo on AMRF Architecture Organization and Procedures, May 15, 1984, File AMRF Agendas 1984 and 1985, AMRF Files, NIST.

Kramer, interview, April 14, 2000.

${ }^{23}$ Scott, interview, June 16, 2000 .

Kilmer, interview, July $28,2000$.

lbid.

Barkmeyer, interview, June 9, 2000.

Nanzetta, as quoted by Barkmeyer, interview, June 9, 2000.
} 
an equal footing; . . . you've got a critical piece, and we're working together to make it work." Such trust in individual contributions further built communication ties and helped the facility grow.

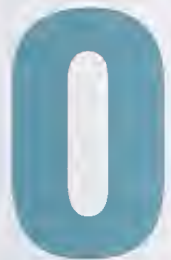

NE EXAMPLE OF THAT GROWTH came from the Vertical Workstation. McLean, who had initially contributed to the cell control system, applied his training in artificial intelligence to process planning. His idea was to have a workstation take a part design and automatically generate the programs needed to cut the metal blank. No human involvement would be needed. But a team of people made this goal possible. Using the artificial intelligence language Lisp, which was the first time an AMRF system had used this powerful language, Alton Quist, an Industrial Research Associate from General Dynamics, Pomona Division, wrote the software to generate the numerical code. Thomas Kramer wrote the software to verify the $\mathrm{NC}$ code and display part features. Jai Jun and McLean wrote the code to control the overall execution of the high-level software processes in the workstation. With Ed Magrab, Fred Rudder, and Denver Lovett designing the hardware out on the shop floor, the Vertical Workstation team produced their process planning system for the June and November 1985 test runs. As demonstrated, most notably by US Commerce Deputy Secretary Clarence Brown in November 1985, a person could select and place a set of simple features onto an imagined part (Fig. 17). Then, the workstation took over. The system wrote a process plan, or manufacturing sequence, to produce

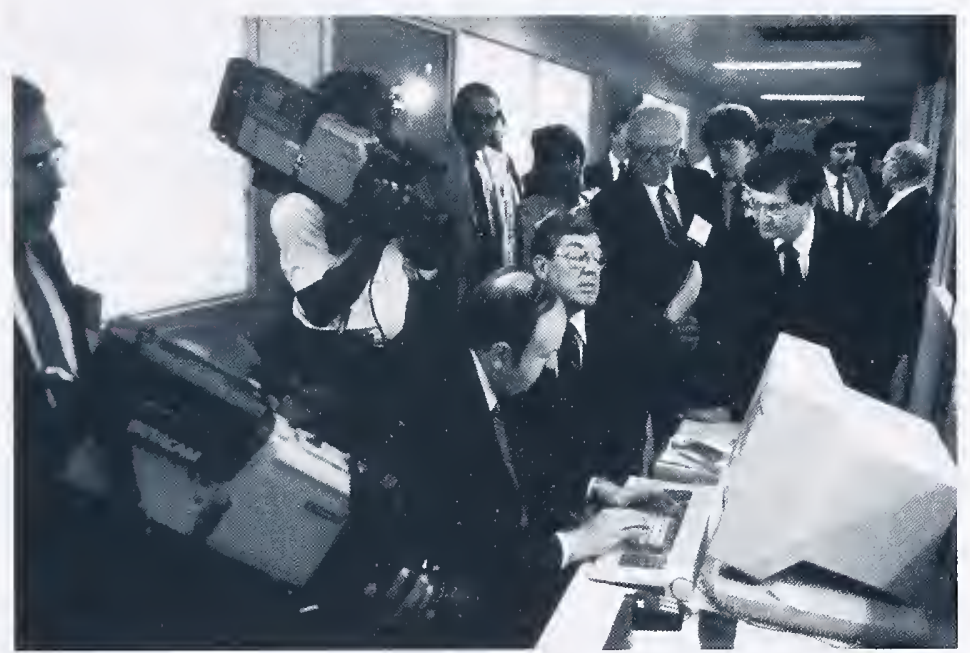

Figure 17. Chuck McLean demonstrates to US Commerce Deputy Secretary Clarence Brown the Vertical Workstation's automated process planning system. (Photo collection, AMRF Files, NIST) that set of features. Next, the software wrote the numerical control code to cut those particular features, verifying the features and machining operations for the given part. This information downloaded into the machine tool, telling it how to make the piece. And, cutting began. ${ }^{28}$ Within 20 minutes of sitting at the computer, deputy secretary Brown received a brass piece with 15 holes, pockets, and grooves that he had designed. ${ }^{29}$ To emphasize this remarkable speed of manufacturing, Director Ernest Ambler noted that "Redesigning and refitting the machines was something that used to take days or weeks." ${ }^{130}$

No one had seen such a thing. Some people didn't quite believe the process had become totally automated. McLean remembered one vice president of Kennametal, a cutting tool manufacturer, stating in disbelief, "They can't really be doing what we're seeing here. They've got a bunch of people in the back room who are writing this." ${ }^{31}$ Dave Sandora, a Kennametal guest researcher, replied to the vice president that if there were people in the

\footnotetext{
${ }^{2}$ Thomas R. Kramer and Jau-shi Jun, "Software for an Automated Machining Workstation," paper presented at the International Machine Tool Show Technical Conference, Chicago, IL (September 1986), 1; "Vertical Workstation Capabilities Enhanced," no date, File Phil Nanzetta Chron File March 1987, AMRF Files, NIST; Kramer, interview, April 14, 2000; McLean, interview, June 2, 2000.

${ }^{29}$ Mike Clem, "Engineering Lab in Gaithersburg Does Research Unique in Nation," Frederick News-Post (November 21, 1985), and Cheryl Hogue, "Robots into the Groove at Bureau of Standards," Montgomery Journal (November 21, 1985), 1, both in File Press Clippings, AMRF Files, NIST.

${ }^{30}$ Ambler, quoted by Clem, in "Engineering Lab in Gaithersburg."

Kennametal manager, as quoted by McLean, interview June 2, 2000.
} 


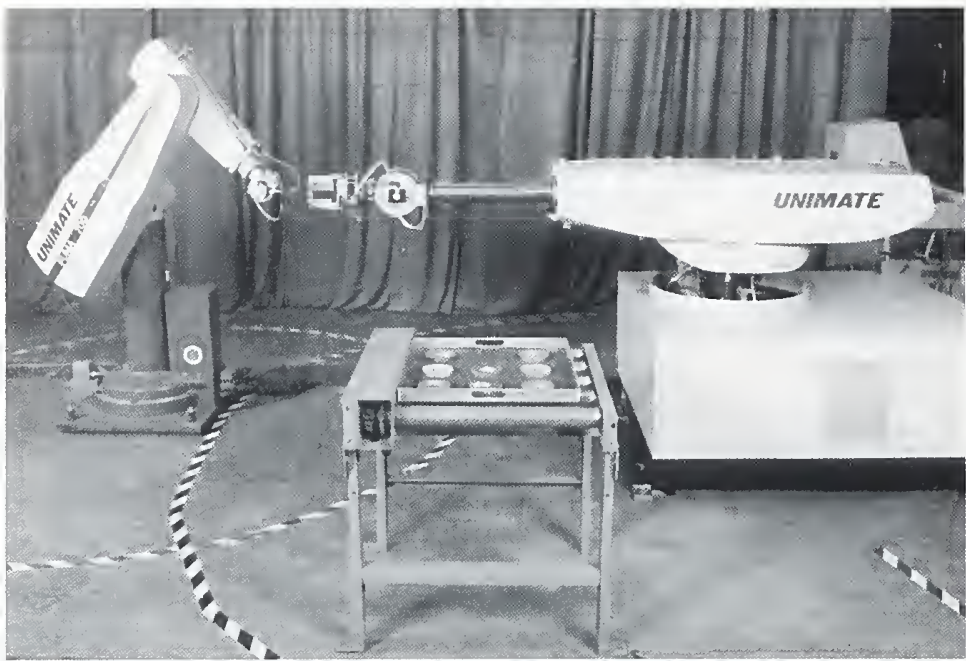

Figure 18. The only AMRF workstation with collaborative working robots, the Unimate 2000 and Puma 760 worked together to debur parts. (Photo collection, AMRF Files, NIST)

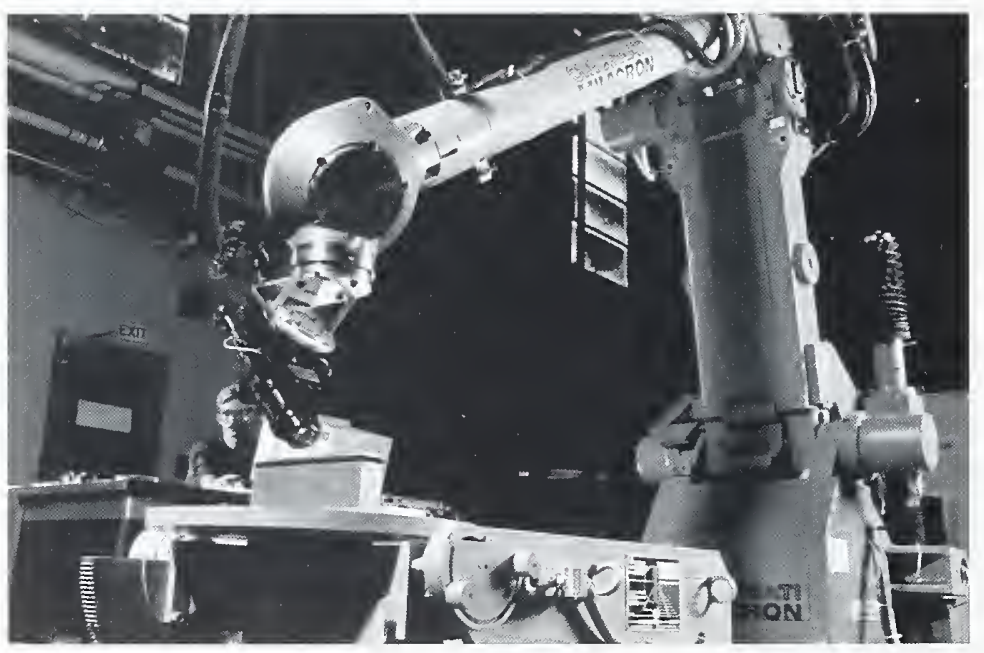

Figure 19. The Advanced Deburring and Chamfering System (ADACS) used hard cutting tools to clean such advanced materials as titanium. (Photo collection, AMRF Files, NIST) backroom performing the process planning, they would have made too many errors, and it would not have worked correctly the first time. Manual planning and process programming typically took days in most facilities. Automation offered a productive alternative. Further refinements to the robot by Magrab and his co-workers allowed the grippers to rotate after having grasped a part blank. This feature made it possible for the machine tool to conduct some multiple-surface milling. The robot could also change its fingers, allowing it to lift small pallets and grasp tool adapters for insertion into the machine tool's tool changer. These modifications increased the flexibility of the entire system and allowed the workstation to conduct multiple layers of tasks. And, once the machine tool had finished its job, a vacuum chip removal system, designed by the Vertical Workstation team, picked up stray metal chips around the part in the tool cutting area. ${ }^{32}$

More cleaning of parts went on at the Cleaning and Deburring Workstation (CDWS). This station

(Fig. 18) had the remarkable characteristic of coordinating two robots, a small Puma 760 and a larger Unimate 2000. Rick Norcross, following the lead of the WWS team, designed the Cleaning and Deburring Workstation controller in Lisp, allowing the two robots to work independently on separate tasks or in combination at a single task. Flexibility was a guiding design feature of this workstation. Once a part arrived via the robot cart, the Unimate picked it up and placed it in a pneumatic vise for deburring. This task done, the part could be sent to the washer/dryer system to remove cutting fluids, oils, or other foreign materials, or it could be picked up by the Unimate 2000 and held to the buffing wheel for further processing. Washing and drying would then follow. To add even greater flexibility to deburring methods and increase productivity, team members Pete Tangy and Karl Murphy experimented with collaboration of the two robots. From the perspective of viewers, in a delicate dance of

\footnotetext{
"Vertical Workstation Capabilities Enhanced;" Mclean, interview, June 2, 2000; Kramer, interview, April 14, 2000, NBS, "Vertical Workstation," videotape, no date, AMRF Files, NIST.
} 
two heavy-armed robots, the Unimate re-oriented the part based on a sequence of grip points, with the Unimate controller automatically filling in the paths between the points. The Puma robot then applied the deburring tool based on a corrected nominal tool path generated at the workstation. The robot's path started about 1-inch above the point and proceeded into the part. A force sensor identified the part and the nominal point was replaced by the "sensed" point. The Puma then ran the path with the corrected points to debur the part. The procedure compensated for tool wear and robot errors. Such cooperative action between robots made for quite a show in AMRF demonstrations and photographs shared with the news media. Eventually, the workstation would undergo further refinements to become the Advanced Deburring and Chamfering System (ADACS, Fig. 19), capable of cleaning advanced metals like titanium with hard cutting tools, as opposed to the monofilament brushes used at the Cleaning and Deburring Workstation. ${ }^{33}$

Inspection came last. Here, Ted Hopp and his workstation team members achieved what industry had long wanted: having the original computer-aided design (CAD) data file for a part generate a control program to drive the 3-dimensional coordinate measuring machine (CMM). Such a feat required first some understanding of the intricacies of the CMM. The basic mechanics of an inspection machine could be explained in relatively fast order. But, as Hopp later recalled, "there is a big difference between that and having a person actually get on and do it., ${ }^{, 34}$ Always at the back of his mind was the fear of breaking the delicate and expensive $\$ 2000$ probe (Fig. 20), a force-sensitive mechanism with a synthetic ruby tip. After a week-long course run by the CMM's manufacturer, Hopp came to appreciate and work with the subtleties of the machine. ${ }^{35}$ In the end, he could say with pride that he never broke a probe, only bent a couple. But, his experiences with the Inspection Workstation taught him "a lot of respect for these guys who do this all the time. I didn't appreciate how difficult it was. . . I was quickly disabused of that.",36

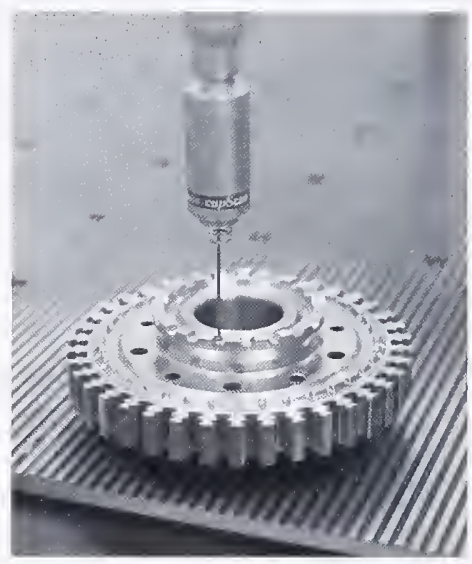

Figure 20. Inspection Workstation team members successfully used the computer-aided design (CAD) data file for a part to generate a control program for driving the Coordinate Measuring Machine's delicate probe. (Photo collection, AMRF Files, NIST)

For the AMRF, the Inspection Workstation (IWS) sat in a twenty degrees Celsius temperature-controlled corner room. A robot mounted upside down to allow the greatest freedom of movement transferred a part from the robot cart first to the surface roughness instrument (SRI). Using an automatic dial indicator, the robot positioned the part at a precise distance from the SRI head. Then, a light would shine down on the part and scatter, based on the part's surface features. Detectors in the SRI measured the degree of scattering, allowing for calculation of the average roughness. This task done, the robot picked the part back up and placed it on the CMM table and went on to check the surface roughness of another part. The IWS distinguished itself by being first to handle such dual tasks at once. Back to the CMM, with the probe at the end of a horizontal arm, the machine

\footnotetext{
${ }^{33}$ Norcross, interview, August 25, 2000; Kilmer, interview, July 28, 2000; Richard J. Norcross, "A Control Structure for Multi-Tasking Workstations," Proceedings of the 1988 IEEE International Conference on Robotics and Automation, Philadelphia, PA (April 24-29, 1988), 1133; Harry G. McCain, Roger D. Kilmer, and Karl N. Murphy, "Development of a Cleaning and Deburring Workstation for the AMRF," no date, 6, 8-10, 12-13, 15, File Cleaning and Deburring Workstation, AMRF Files, NIST; Karl N. Murphy and Frederick M. Proctor, "An Advanced Deburring and Chamfering System," paper presented at the Third Intemational Symposium on Robotics and Manufacturing, British Columbia, Canada, July 1990, 2-4, File ADACS, AMRF Files, NIST

Hopp, interview, June 30, 2000.

35 Ibid; Howard T. Woncarz, Stephen A. Osella, Bruce Borchardt, and Ralph Veale, Operations Manual for the Inspection Workstation, NBSIR 88-3766 (Gaithersburg, MD: National Bureau of Standards, 1988), 3, File I 1983, AMRF Files, NIST.

${ }^{36}$ Hopp, interview, June 30, 2000.
} 
touched the part and recorded the touchpoints for determination of the part's shape. CAD data, downloaded from an AMRF database, drove this process, rather than having a human inspector program the machine. This accomplishment promised time and economic savings to companies, a plus since industry representaiives had often viewed inspection as a necessary evil. Manufacturers proved to their customers through inspection that they delivered parts within the necessary tolerance limits. But CMMs and the time spent using them cost money beyond production costs, and therefore companies sought any means to reduce these extra expenses. Automated inspection offered one such possibility. ${ }^{37}$

One problem arose as a result of this research. By the 1990s, Hopp and his team members had determined that software errors threatened to skew the results of computer-driven inspection. If software is a tool for transforming raw measurement data into inspection data for analyzing a part, then the nature of the software errors become as important as the mechanical and electronic errors of what was actually used to measure the part. Simulated data fed into inspection software could be measured and read for its level of errors. Through this process, the software could be calibrated to ensure measurements are true to the actual part being measured. This work resulted in the first software calibration service ever approved by the agency. Hopp admitted later "it was a real culture shock" ${ }^{\prime 38}$ to have calibration of code as opposed to physical objects, but the idea behind both is the same, making sure the measurements are true.

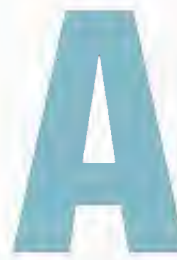

DDITIONAL RESEARCH AVENUES had been pursued in other workstations in the mid-1980s in support of the ever-present demonstrations. The team for the Turning Workstation (TWS, Fig. 21), while studying communications and process control in the workstation, focused on the idea of having untended manufacturing for an extended period. They developed a special gripper about half the weight but able to exert about ten times the programmable holding force of the best commercially available equipment. With its special interchangeable fingers, the gripper allowed the robot to tend to a variety of tasks automatically. A malfunction detector, dubbed the "disaster sensor," measured unacceptable

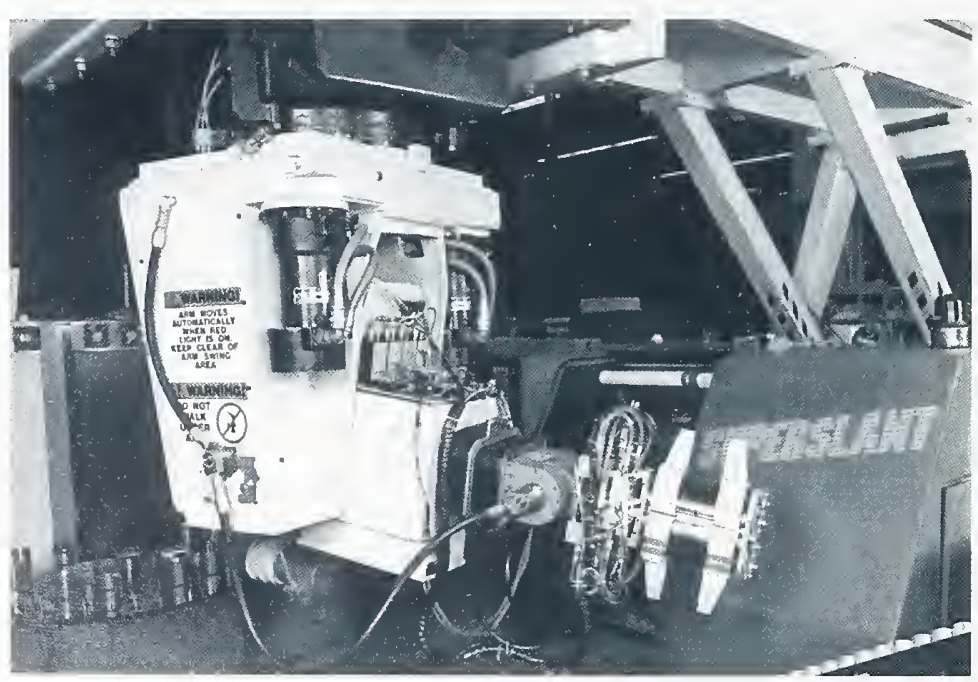

Figure 21. In 1985, the Turning Workstation achieved continuous untended production when it machined 150 standard reference material containers over a 25-hour period. (Photo collection, AMRF Files, NIST) vibration levels in the machining process. Based on the signature of the vibration signal, the disaster sensor could determine the absence of a blank, excessively dull tools, broken tools, improper sequencing of operations, or excessive time for any operation or between operations. Error messages sent to the workstation controller would stop the work or correct tool position or cutting speeds to prevent potentially serious damage to the system. Automated tool setting, to change cutting devices in the machine tool,

\footnotetext{
Hopp, interview, June 30, 2000; Moncarz, Osella, Borchardt, and Veale, Inspection Workstation, 3, 6; "Metalworking Electronics," Machine and Tool Blue Book (April 1983), Black Binder News Releases 12/82-6/85, AMRF Files, NIST.

Hopp, interview, June 30, 2000
} 
and collet changing capabilities, to change the fixtures to hold different parts, allowed the Turning Workstation team to realize its goal. In 1985, the TWS conducted continuous untended operation for 25 hours, producing more than 150 standard reference material containers for the Bureau. In other untended test runs over a twoweek period, the workstation manufactured 1,000 containers, with the malfunction detector averting several tool breakages due to machine tool failure. As TWS leader Kang Lee later reported, the Bureau was so impressed with these results that it ordered additional containers with a more intricate design. ${ }^{39}$

OLLOWING ITS OWN RESEARCH GOAL, the Horizontal Workstation (HWS) team had its system reach a high level of development in relationship to the overall AMRF infrastructure. The HWS was fully coupled to the AMRF control and database systems, using sensors to feed information from the workstation to the control system. The robot vision system advanced from the 1983 demonstration to adjust automatically to sudden changes in background light and deal with objects of varying or uneven surface finish. The robot's quick-change wrist could handle connections for electrical, electro-optical, pneumatic, or hydraulic signals. Both Cincinnati Milacron and Westinghouse investigated this design for future devices. The T3 robot gripper, also designed at NBS, had good range of motion and excellent bearing and positioning abilities despite its lighter weight and more compact design than commercially available ones. $^{40}$

Each workstation could run autonomously but the real test was coordination. How best could the researchers organize all of the information needed to allow the robot cart to take blanks to the Turning Workstation, pick up parts from the Vertical Workstation, deliver new tools to the Horizontal Workstation, and carry finished pieces to get cleaned and inspected? How best could researchers handle the comparatively large $\mathrm{CAD}$ data files carrying design information for milling a widget without breaking the file down and destroying its integrity? And, how best could testers keep track of each change to a system so that they delivered the correct version as needed? These were issues that people like Mary Mitchell, Edward Barkmeyer, Cita Furlani, Don Libes, and Howard Bloom wrestled with in tying together the disparate workstations of the AMRF. They relied on James Albus's hierarchical control model to frame their answer in a distributed database system called IMDAS. Short for Integrated Manufacturing Data Administration System, IMDAS was a hierarchical control system with control functions separated from data functions. ${ }^{41}$

IMDAS provided access to the several existing databases distributed over the facility's many computer and database systems, allowing for both updates and retrievals. Using a standard language and methodology developed with Professor Stanley Su and some of his graduate students at the University of Florida, Gainesville, control or planning programs could query IMDAS for information. These programs did not need to know for themselves where the data was stored, only to make a request through the distributed database system. IMDAS used a "data dictionary" to locate the requested information and Su's standard language to communicate the data to the varied workstations. IMDAS set itself apart from other distributed databases in the mid-1980s, winning an award from the Massachusetts Institute of Technology, because it physically distributed information based on

\footnotetext{
${ }^{39}$ Alkan M. Donmez, et al., The Turning Workstation in the AMRF, NBSIR 88-3749 (Gaithersburg, MD: NBS, 1988), 3-5, 13, 16, 18, File Turning

Workstation, AMRF Files, NIST; Brian W. Rooks, "Encouraging Industry to Invest in Future Technology," Industrial Robot 13 (March 1986): 31 ; Lee, interview, April 7, 2000; Joyce, "Factories Will Measure," 49.

40 Rooks, "Encouraging Industry," 30; "Tool Handling Advancements," Robotics Today (1986), File Press Clippings, AMRF Files, NIST.

Mitchell, interview, May 5, 2000; Bloom, interview, March 3, 2000; Edward Barkmeyer and Jane Lo, Experience with IMDAS in the Automated Manufacturing Research Facility, NISTIR-89-4132 (Gaithersburg, MD: NIST, 1989), 4-5.
} 
what system had ownership rights and what system created the information. The logical division of the database was essentially tied to the owners who created the information. ${ }^{42}$

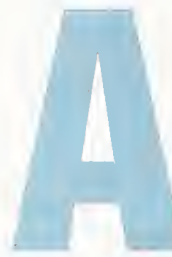

S A PROTOTYPE, IMDAS HELPED address the problem of real-time data management for the AMRF. With different operating systems and computer languages throughout the facility, IMDAS allowed data management no matter where that data might reside. ${ }^{43}$ Yet, it started out doing that data management in super slow motion. For Tom Kramer on the Vertical Workstation team, he found that "IMDAS was a big headache for us because it was so slow." "it Rick Norcross, who worked on the Cleaning and Deburring Workstation, related that because IMDAS was slow, with as much as ten minutes needed to retrieve data, "you would fetch the data first and then freeze the workstation, and when they [the visitors] came close, you [would] hit the carriage return and everything [would] start moving." Norcross considered many demos to be canned. But, he also understood that there had to be problems. "If everything's working, then why bother doing [the research]?" ${ }^{46}$ And, IMDAS did improve with time. For its first appearances in December $1986^{47}$ and mid-1987, response times varied from 30 seconds to several minutes, making the system "totally inadequate for supporting production manufacturing." ${ }^{48}$ By 1989, response times improved considerably, ranging from 5 to 45 seconds. ${ }^{49}$ These times still would not have seen useful application in a production facility, but, as Howard Bloom later noted, "our intent was not to develop a product per se, it was a means to an end" ${ }^{\prime 50}$ to manage a huge amount of data.

\section{Performances}

With or without IMDAS running at speedy rates, public demonstrations through the mid- to late-1980s continued to include sleepless nights, taxed nerves, and a fair share of humorous stories. Those long nights played tricks on some researchers. Cita Furlani, who worked on IMDAS, remembered walking into her dark ground-floor office in the middle of one night and having two large luminous eyes stare at her. Once her heart had skipped a beat or two, she turned on the light and realized that a deer, common on the NBS campus, was just outside her window. No harm, but it was a reality check to how long she had been away from everyday life. ${ }^{51}$ Similarly, Texas Instruments guest researcher Mark Luce recalled that he and his fellow researchers in a basement office lost all track of time while preparing for one demo. A security guard even questioned them once about what they were doing there so early in the morning. Without watches or clocks and no windows to mark time passages, the researchers actually thought it was late at night. They had been sleeping there and working for days. "We were demo driven, had to put on a show," Luce commented. "The work leading up to that was tiring but it was

\footnotetext{
\$2 Mitchell, interview, May 5, 2000; "What is the AMRF?" November 1989, 7-8, File 1989 AMRF Overall, AMRF Files, NIST; Barkmeyer, interview, June 9 , 2000; Bloom, interviews by author, March 3, 2000 and April 7, 2000, audiotapes, NIST.

${ }^{43}$ Bloom, interview, April 7, 2000.

"Kramer, interview, April 14, 2000

"Norcross, interview, August 25, 2000

${ }^{96}$ Ibid.

Cita Furlani, "IMDAS Provides Interface from Generated Data to Control Modules," 3, File Phil Nanzetta Chron File March 1987, AMRF Files, NIST.

Barkmeyer and Lo, Experience with IMDAS, 6.

Ibid, 6-7.

Bloom, interview, April 7, 2000.

Furlani, interview, March 24, 2000.
} 
rewarding because when a system actually worked, everyone walked away with some level of excitement because of this major achievement. It was really rewarding."

Phil Nanzetta's rule of no changes after successful integration testing also resulted in a memorable demo story. The Horizontal Workstation team had an occasional recurring problem that kept the workstation from operating. Needless to say, the team wanted to find a solution before the demonstration. After testing one day, team members discussed the problem and came up with a fairly simple fix which, if implemented, they felt confident would not threaten the system as tested. As the lead, Harry Scott took responsibility and sat down to start making the changes. "Word spread like wildfire," Scott later said. "I'm sitting on the shop floor and ... I see Jim Albus come running all the way down to the door which is on the other end and coming around the corner, and I'm racing trying to change it, and he knew I was making the change, and I knew he knew I was making the change, but I had to get it done before he got there so he wouldn't stop me in mid-change." ${ }^{53}$ Scott got the change in and explained his reasons to Albus. "And, of course, Jim is an extremely reasonable person, he was obviously made nervous by this, but he had confidence that we were doing the right thing." ${ }^{54}$ With the change made, the problem disappeared with no known repercussions to the system.

T ANOTHER TIME, a more serious problem plagued the HWS team and pressure mounted as demo day neared. Scott described the scene as "it was as hot as it gets to get something fixed." and his fellow primary developer Kathleen Strouse were receiving advice from everyone and anyone, whether they wanted it or not, making it nearly impossible to focus. So, they disappeared. They found a room away from the others, locked the door, and quickly realized an answer to the problem. Meanwhile, panic set in outside, with people wondering where the developers had gone. Nanzetta did find them eventually and ordered them submarine sandwiches, tacitly supporting their decision to hide.

Nanzetta kept the momentum going for his AMRF team in other ways. He instituted the taking of panoramic photos to celebrate and record the big demonstrations. People looked forward to being in the pictures and even rearranged doctor's appointments or other commitments if they conflicted with a photo time. Bill Rippey from the Horizontal Workstation team called them big occasions which helped unify the group. After the first photos, people even figured out how to stand on one side of the view, get into the photo, and then run fast behind the slowly moving camera to get into the shot a second time on the other side. Nanzetta also helped mark the countdown to one big demo by putting up a poster with cartoon hands: nine weeks to demo, eight weeks, and so on. Rippey, who worked directly for Nanzetta for a time and conducted some of the hallway talks for demos, noted that Nanzetta was always out there and involved, building team cohesiveness. "He was perceptive and energetic and just a good smart worker," ${ }^{, 56}$ Rippey later shared. Such commitment helped during those anxious pre-demo days and during the everyday challenges of figuring out systems. Tom Kramer thought Nanzetta made the AMRF pull together and work. "He made it his business to know what was going on in each workstation, what each workstation needed. . . . He was very good at working with people and keeping things smooth." ${ }^{, 57}$ Linda Wood, Nanzetta's assistant, helped Nanzetta fulfill his mission of communicating with people and staying active.

\footnotetext{
Luce, interview, June 2, 2000.

scott, interview, June 16, 2000.

${ }^{54}$ Ibid.

Ibid.

${ }^{6}$ Rippey, interview, March 10, 2000.

Kramer, interview, April 14, 2000.
} 
Wood kept administrative tasks organized and shared Nanzetta's interest in keeping good public relations, both with outside sponsors and within the AMRF team. ${ }^{58}$

Keeping good public relations with the Navy involved other memorable stories. Before Navy ManTech director Jack McInnis ever gave NBS money for the fledgling automated research facility, he toured the shop floor and met some of the researchers. One person who stood out for him was Bob Hocken, "maybe one of the most unusual individuals I have ever met." ${ }^{, 59}$ At their first meeting, Hocken slid out on a mechanic's creeper, where he had been changing an oil sump on one of the machines, and shook McInnis's hand as someone said, "This is Doctor Hocken." McInnis quickly learned that Hocken had that iare gift to communicate with a host of different people with different backgrounds. He could speak at the level of a group of postdocs just as easily as he could to a visiting class of sixth graders. During the $\$ 600$ hammer fiasco of the mid-1980s, Hocken could even communicate to a group of Navy admirals about why they were paying so much for a hammer. He pulled out a Bic lighter and explained that according to the NBS estimating department, it would take something like $\$ 1,000$ to build such a piece. The darned thing had 12 precision parts. But, Hocken explained, he could go to the corner grocery store and buy one for 59 cents. Bic made a million of these lighters and had an automated assembly. Such was the case with the $\$ 600$ hammer; it was all in the way the Navy was trying to buy them. McInnis noted gratefully that "I think for the first time some of those guys understood that contractors really weren't trying to kill them off. It was the way they were buying things." 60

Once the Navy decided to sponsor the AMRF, NBS put on shows just for the admirals and other higher ups. Hocken remembered one particular presentation involving the first robot cart. One admiral saw the robot cart come trundling by and asked if it was safe. Hocken replied yes, it had bumpers and infrared sensors. So, the admiral stepped in the path of the couple ton cart. It stopped, the admiral was pleased, and the tour continued. Later, when Hocken returned to the floor, one of the people working on the cart ran over. Sweating, he said, "You don't know how lucky you were!" He had just installed the infrared sensors and tested them. "The only reason they worked," as Hocken remembered his co-worker saying, "was because he [the admiral] was wearing his summer whites. If he had been wearing black, it would have run right over him., ${ }^{161}$ Admirals had a special place in the hearts of at least some AMRFers. Tom Kramer of the Vertical Workstation recalled that before demos, team members would joke that someone should "dress up in an admiral's uniform and walk around while we were practicing." Sometimes, it seemed, the bugs always seemed to show up just for the Navy's people. ${ }^{62}$

\section{Graduation}

Bugs or not, the AMRF did flourish and in December 1986 proudly showed its stuff to the world as an integrated automated manufacturing research facility. Navy representatives joined with industry and academia, at the average rate of 128 individuals per day, to celebrate the formal graduation of the AMRF (Fig. 22). An amazing 505 people from 190 companies witnessed the figurative ribbon cutting and demonstrations. They saw all six workstations run under cell control as an integrated unit. For the first time, the Vertical, Cleaning and Deburring, and Inspection Workstations were integrated with the other ones. The vision system and the Horizontal, Cleaning and Deburring, and Inspection Workstations used the new IMDAS system for part information and tracking

\footnotetext{
${ }^{58}$ Rippey, interview, March 10, 2000.

${ }^{59}$ McInnis, interview, May 5, 2000.

${ }^{60}$ Ibid.

${ }^{61}$ Hocken, interview, March 3, 2000.

Kramer, interview, April 14, 2000.
} 


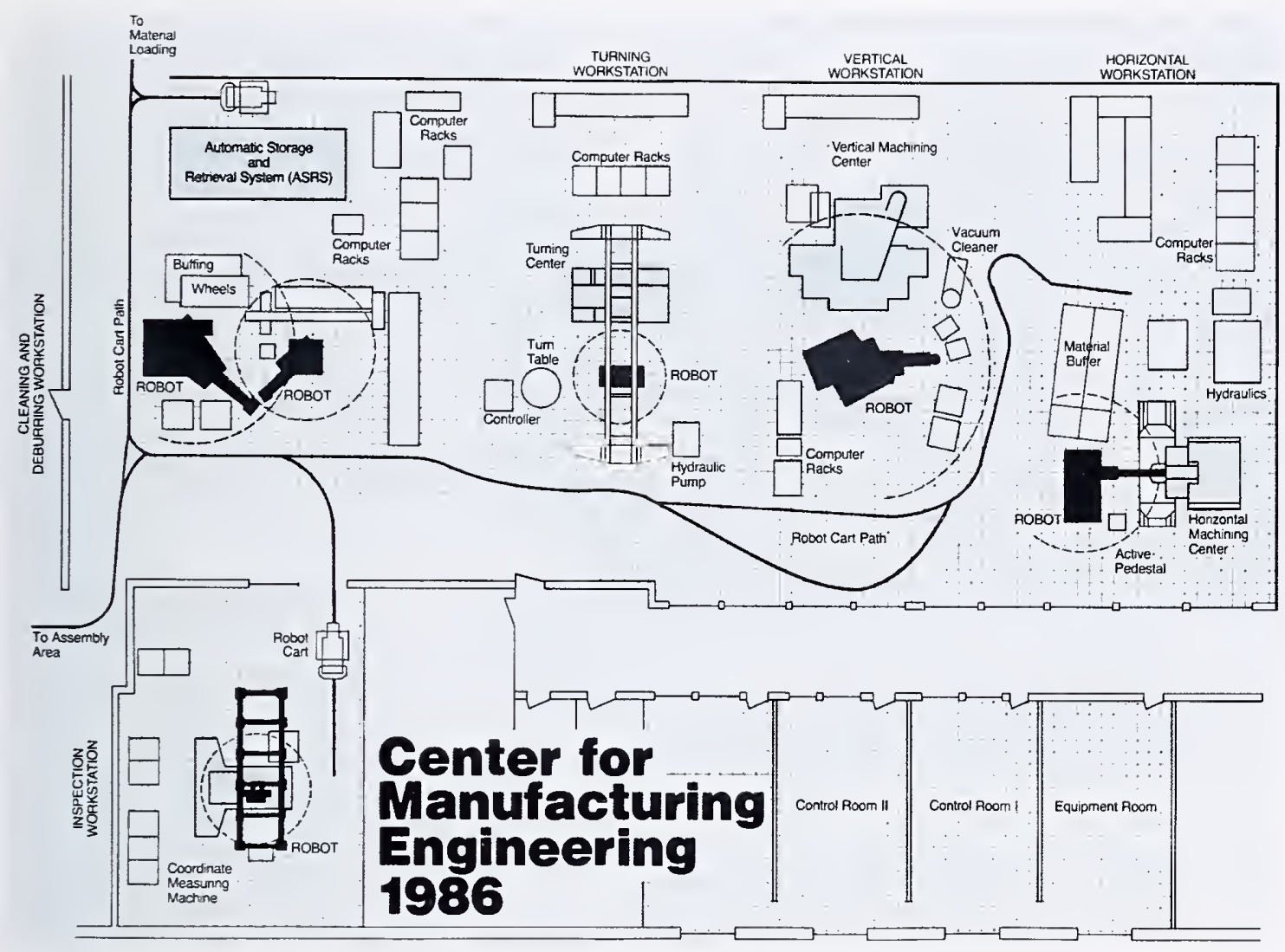

Figure 22. At the 1986 full AMRF demonstration, six workstations ran under cell control as an integrated unit. (AMRF Files, NIST)

activities. Two robot carts kept the workstations loaded with blanks and tools. The dance had expanded from solo or duet routines to a coordinated ballet across the entire AMRF shop floor. ${ }^{63}$

Visitors also celebrated the many achievements and milestones so far completed by the AMRF experiment. In the area of standards, AMRF research supported the adoption of a new method for characterizing coordinate measuring machines (known as ANSI/ASME B89.1.12). This standard provided a thorough set of functional tests of the machines' performance, including the effects of the environment, to enable CMM users to understand and compare the real capabilities of this new type of measuring equipment. This new approach made deployment of CMMs throughout industry much easier and made US companies like Sheffield and Brown \& Sharpe more competitive in the worldwide CMM market. ${ }^{64}$ Another seven standards proposals were under consideration at the time of the graduation exercises, focusing on robotics, data exchange, factory architecture, and networking.

The Bureau of Standards also proudly trumpeted the many commercial adaptations and more than a dozen patents resulting from AMRF research. Valeron and Technovations made commercial applications of the

\footnotetext{
${ }^{63}$ Memorandum, Phil Nanzetta to John Simpson, January 14, 1987, Attendees at AMRF December Public Test Run; and Philip Nanzetta to Richard Kane, January 9, 1987 and accompanying memorandum Grist for the Conference Room Script December AMRF Test Run, December 2, 1986, both in File Phil Nanzetta Chron File Jan 1987, AMRF Files, NIST. The ideas of graduation and ribbon cutting are expressed in the following pieces: Remarks by John A. Simpson, Director, CME, to National Academy of Sciences Panel for CME; and Long-Range Plan for CME, October 1984, both in NBS Packet for NAS Panel, December 17-18, 1986, File J-140, John Simpson's Files, MEL, NIST; Proposed Remarks for John W. McInnis, Director, Navy Manufacturing Technology Program, AMRF News Briefing, December 9, 1986, in packet with Nanzetta to Kane cover letter, January 9, 1986.

(4. "Standard for Performance Evaluation of Coordinate Measuring Machines," Industrial Neus (October 1985), Black Binder, AMRF News Clippings, AMRF Files, NIST; Charlton, interview, May 8, 2000; Grist for the Conference Room Script.
} 
Drill-Up drill wear detector designed early in the AMRF days. Automatix used the structured light system idea from Jim Albus and developed by Ernie Kent for robot vision. In addition to the CMM standard, both Sheffield and Brown \& Sharpe also benefitted from the software error correction methods conceived by Bob Hocken and implemented by Tom Charlton. Allen Bradley, Honeywell, and Martin Marietta used versions of the robot control system developed by Tony Barbera and others while Boeing adopted the real-time control system for its manufacturing. More companies used quick change wrist connections, automatic tool settings, and process planning systems developed by AMRF scientists. There could be no question that the first five years of hard work had resulted in impressive technology transfers. ${ }^{65}$

RADUATION ALSO CAME WITH RECOGNITION to some of the moving forces behind the AMRF. John Simpson won the prestigious AM Award from the editors of American Machinist $\mathcal{E}$ Automated Manufacturing for his work in applying measurement science to controlling machining processes and for helping to develop the AMRF. Simpson joined the ranks of such important past figures in manufacturing as roboticist Joseph F. Engleberger. ${ }^{66}$ Jim Albus, Bob Hocken, and Phil Nanzetta individually received the Department of Commerce's highest award, the Gold Medal. ${ }^{67}$ These awards noted the importance of their work in advancing industry and, as noted on Hocken's award, for providing "the best hope for the nation to regain its leadership in manufacturing.", Ernie Kent shared an Industrial Research magazine IR-100 award with two fellow researchers at Digital/Analogue Design Associates for their work on the invention and development of an advanced parallel-architecture computer designed for real-time image processing to support the robot vision system. The entire AMRF team also received the first group award ever made by the Federal Laboratory Consortium for Excellence in Technology Transfer. As Simpson noted to a National Academy of Sciences Review Panel the week following the December demonstration, "we are very proud" of these awards. ${ }^{69}$

Graduations mark both the achievements of the past and the paths for the future. Some AMRFers chose to follow separate paths. By the time of the December 1986 demonstration, Ernie Kent had gone to North American Phillips to serve as director of research in information sciences while Tony Barbera and Mary Lynn Fitzgerald had taken their expertise in real-time control systems to Martin Marietta. Within the year, Tom Charlton joined Brown \& Sharpe to apply AMRF work on CMMs in an industrial setting. By the end of 1988, Bob Hocken accepted an endowed professorship in precision engineering and directorship of the manufacturing laboratory at the University of North Carolina, Charlotte. Hocken continued research in automated manufacturing, even using the original Horizontal machining workstation once it "graduated" from use in the AMRF. These significant losses in personnel certainly took a toll on the collective wisdom of the project. One effort to reduce their intellectual impact involved documenting each workstation in the facility. This task met the calls by the Navy sponsor for aiding the transfer of AMRF technology to other Navy projects. And, this effort helped open new avenues of research which the remaining team addressed with its characteristic energy and determination. ${ }^{70}$

\footnotetext{
"Grist for the Conference Room Script; United States Department of Commerce, NIST, Getting It Right, Making It Better, videotape, December 1992. The Brown \& Sharpe Validator was the first CMM to offer software error compensation in a product.

60 "The All Award: Dr. John A. Simpson," 58

Albus and Hocken received their gold awards in 1986; Nanzetta received his in 1987

Award recognition, as quoted by Simpson, Remarks to NAS Panel.

Remarks by Simpson to NAS Panel.

Kent, interview, April 28, 2000; Charlton, interview, May 8, 2000; Memorandum, Phil Nanzetta to Jim Albus, et al., January 7, 1987,

Seminar/Presentation on Documentation, 1, File Phil Nanzetta Chron File Jan 1987, AMRF Files, NIST; Remarks by Simpson to NAS Panel. Kent stayed at Phillips for five years and then returned to the agency, renamed NIST, to delve into research again.
} 
One new research project for the Mare Island Naval Shipyard, located near San Francisco, gave AMRFers experience in the social as well as technological aspects of automation. Former Turning Workstation team members Kang Lee, Charles Yang, and Alex Slocum faced the difficult challenge of developing a single automated workstation to manufacture 40 different pipe connectors ranging in weight from half a pound to 150 pounds and varying in diameter from 1.25 to 11 inches. These connectors, made from solid nickel-copper blanks, provided critical sound inhibition to protect the location of the vessel. Formerly, Mare Island machinists took on average 17 hours to manufacture one part manually. With the new workstation, production time decreased to almost 20 minutes. With NBS guidance, the Navy purchased a Warner-Swasey WSC-12 turning center, a Westinghouse Unimate 6000 open gantry five-axis robot, and two Kardex Industriever 8000 automated storage and retrieval system units. The Unimate robot could handle the wide assortment of

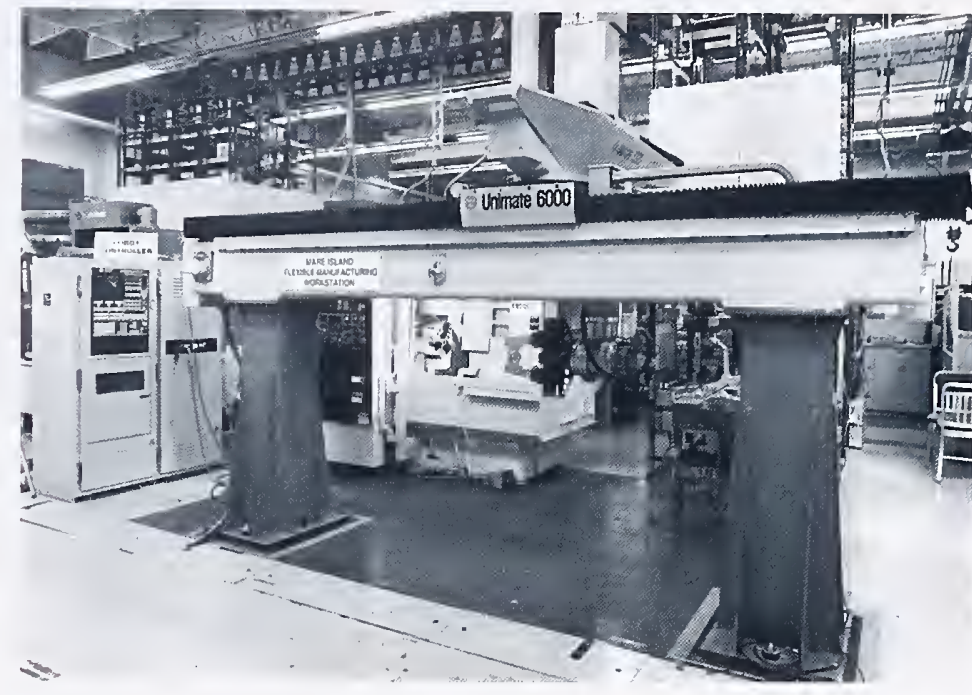

Figure 23. The Mare Island Flexible Manufacturing Workstation promised to reduce production time of critical sound-dampening pipe connectors from 17 hours to almost 20 minutes. Unfortunately, nationwide downsizing of the military and shipyard worker resistance contributed to its transfer to a civilian educational role. (Photo collection, AMRF Files, NIST)

weights and sizes necessary. Slocum developed a gripper system allowing for fine positioning and force control, in addition to having interchangeable fingers to grasp a range of objects. An enhanced version of the original Turning Workstation's malfunction detector sensor monitored the signal from the machining process to detect tool wear and breakage. A hierarchical control architecture for the workstation controller coordinated the workstation's activities. The entire system, written in PLM86, ran on an Intel System 310/286 microcomputer with a 40 megabyte hard disk. ${ }^{71}$

The social challenges of implementing the Mare Island Flexible Manufacturing Workstation surpassed the technological ones in building it. Shipyard personnel put up substantial resistance to the new automated workstation, despite efforts by Kang Lee to assist in the installation of the center and training of the machinists. Within three months of delivery of the workstation (Fig. 23), the situation worsened when the US government, due to nationwide downsizing efforts throughout the armed forces, announced a thirty percent work force reduction. CME director Simpson likened the situation to a disaster, remembering that Mare Island shop people blamed the robot for taking over their jobs, which was not the case. But, the newly renamed National Institute of

\footnotetext{
Charles Yang and Kang Lee, "Integration of Real-Time Process Planning for Small-Batch Flexible Manufacturing," paper submitted to the International Association of Science and Technology for Development, Twelfth International Symposium, Robotics and Manufacturing, Santa Barbara, CA, November 13-15, 1989, 230-34, Kang Lee and Charles Yang, "Mare Island Flexible Manufacturing Workstation," International Conference on Computer Integrated Manufacturing, Rensselear Polytechnic Institute, Troy, NY, May 23-25, 1988, 9-18, both in File Mare Island, AMRF Files, NIST; Philip Nanzetta, "Technology Transfer from the Automated Manufacturing Research Program at the National Institute of Standards and Technology," in Richard H. F. Jackson, ed., Manufacturing and Automation Systems: Techniques and Technologies: Three Pillars of Manufacturing Technology, vol 45 of Control and Dynamic Systems: Advances in Theory and Atplications, edited by C. T. Leondes (San Diego, CA: Academic Press, Inc., 1992), 328-29; Phil Nanzetta, "What is the AMRF?" November 1989, 13, File 1989 AMRF Description, AMRF Files, NIST. The original AMRF

Turning Center and robot went to the Maryland Science Center in Baltimore to be exhibited in the "Your World Maryland" exhibit. See Phil Nanzetta to Mat Heyman, memorandum, Maryland Science Center and Mare Island Naval Shipyard, June 16, 1987, File Phil Nanzetta Chron File June 1987, AMRF Files, NIST.
} 
Standards and Technology (NIST) and the Navy had not done the necessary education and integration of new technology with current workers, creating a volatile mix. In the end, the Navy declared surplus the class of submarines that the workstation was designed to support. Mare Island closed and, as part of the negotiated agreement with the local community, all shipyard machines went to the community college for training purposes. So, the workstation transferred to civilian control. And, NIST had an opportunity to rethink its advancement of automation technology. ${ }^{72}$

\section{UCKILY, THE AGENCY HAD THE IMMEDIATE OPPORTUNITY to apply its lessons learned} from Mare Island to another Navy project, this time for the Portsmouth (New Hampshire) Naval Shipyard. Portsmouth needed level 1 fasteners, such as bolts, studs, and cap screws, made from kmonel, an abrasive, gummy, and difficult-to-machine nickel-copper-aluminum alloy. Outside vendors had balked at the small lot sizes, quick turnaround times for production, precise tolerances for the fasteners, and stringent material traceability requirements. These fasteners essentially held critical parts of submarines together and their breakage threatened the survivability of the entire vessel. For this reason, the Navy required that they be made only of certified raw stock and that their production have a strict audit trail. These requirements increased the cost and time of manufacture. Without outside vendors bidding on the production of these fasteners on an as-needed basis, the Navy kept a large inventory of numerous types and classes of fasteners, adding to costs. With the 1990 Fastener Quality Act signed into law, Congress directed NIST to establish a laboratory accreditation program to ensure that fasteners used in safety-critical applications be certified for quality before being traded in the marketplace. With this charge, the AMRF team stepped in to find a solution. ${ }^{73}$

Mare Island provided valuable experience in both the social and technical aspects of addressing the difficulties at Portsmouth. To combat the social resistance to the workstation idea, AMRF scientists invited the lead Portsmouth programmer to visit the agency and work with the scientists on a generic numerical control program. His skepticism turned to full-fledged support once he saw how committed the AMRF folks were to the project. As Lee recalled, "After two weeks of interacting with us, he became convinced that it could be done. Later on I was told he went back to the shipyard, and he became a crusader, convincing other programmers that . . . it was workable." ${ }^{, 74}$ Three programmers took turns coming to the agency, helping to build a team between NIST and Portsmouth. Another team-building exercise came from the Portsmouth machine shop superintendent Mike Desjardins, whom Kang Lee characterized as a shipyard technology visionary. Desjardins agreed to buy the entire crew all the lobsters they wanted if the workstation was delivered within two years. In the summer of 1992, within the two-year limit, Lee and others enjoyed a huge lobster dinner after installing the Fastener Workstation (Fig. 24). This station, selected by Portsmouth and NIST representatives, included a Brown \& Sharpe Turning Center with bar feeder to have continuous feeding of blanks. A computerized engraving system marked each part before leaving the workstation, uniformly designating the lot-identification number, shipyard designation code, and material code for traceability. Other technical components included a sensor-based tool wear compensation system. Touch probes and thread gauging devices in the Turning Center gaged in-process part characteristics and fed information back into the workstation control system, again run on a hierarchical control system, to ensure

\footnotetext{
${ }^{72}$ Nanzetta, "Technology Transfer," 329; Simpson, interview, 1993; Lee, interview, April 7, 2000.

${ }^{73}$ Kang B. Lee, "Computer-Controlled Fastener Manufacturing Workstation," Society of Automotive Engineers Technical Paper Series, 941719, paper presented at the International off-Highway and Powerplant Congress and Exposition, Milwaukee, WI, September 12-14, 1994, 1-2; Nanzetta, "Technology Transfer," 329; Philip Nanzetta to Roy Welts, June 10, 1987, Trip Report to Portsmouth Naval Shipyard, File Phil Nanzetta Chron File June 1987, AMRF Files, NIST; Lee, interview, April 7, 2000.

Lee, interview, April 7, 2000.
} 


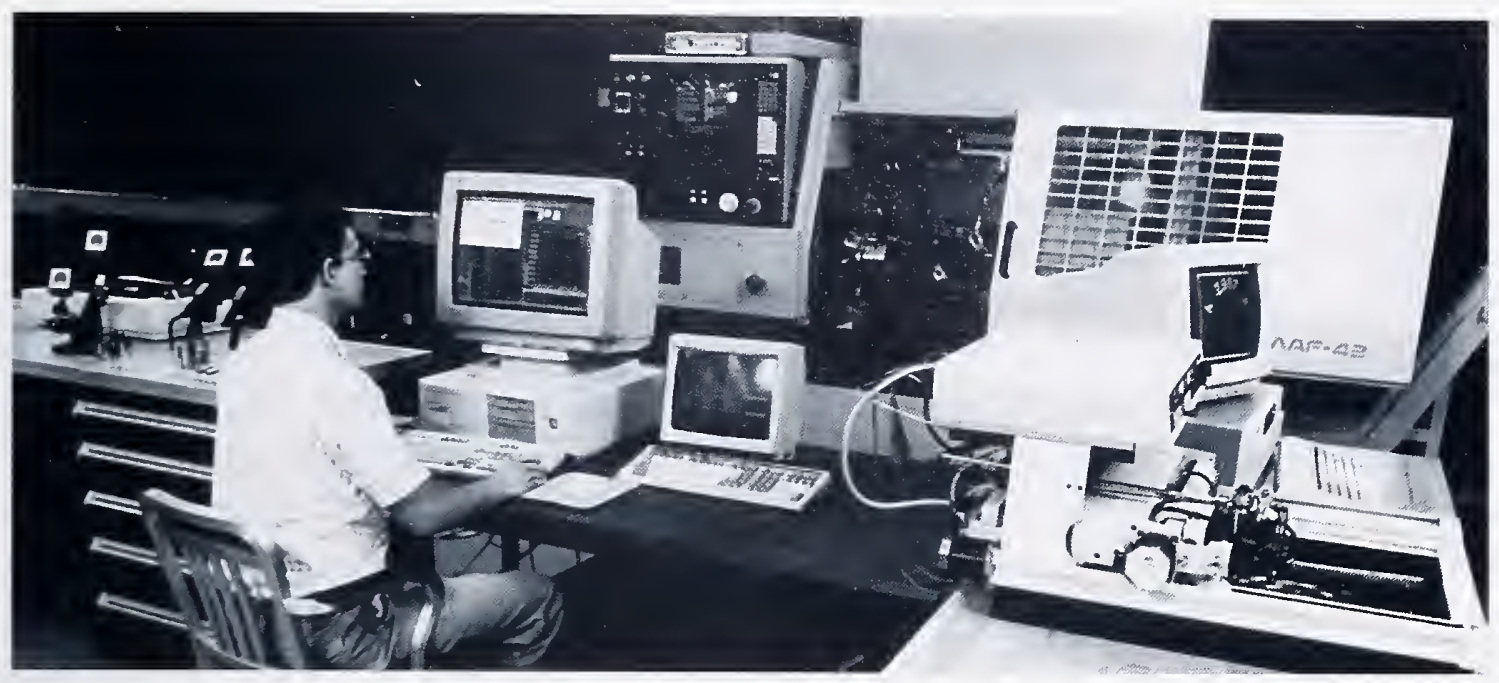

Figure 24. AMRF scientists worked actively with software engineers from Portsmouth Naval Shipyard to build a Level I Fastener Workstation that increased productivity 300 percent and saved an estimated $\$ 900,000$ annually on a three-shift operation.

(Photo collection, AMRF Files, NIST)

fasteners were made correctly the first time and every time. Deburring with rotating brushes followed directly from machining in the Turning Workstation. Finished parts consistently met strict tolerance limits with the virtual elimination of scrap. The Turning Workstation also had twin spindles and three tooling turrets to perform all machining work on a fastener without needing tool or machine changes, helping to reduce production costs. An operator-friendly interface on a UNIX operating system running on an Intel 486 personal computer simplified workstation operation and kept all manufacturing-related data stored in a relational database, removing the need to hunt for drawings, NC (numerical control) programs, process plans, tolerances according to various standards, and other manufacturing information. With delivery of the system, thanks to active involvement of the Navy customer throughout the process, Portsmouth personnel embraced the system as their own and used it. Success resulted. Production data demonstrated that fastener manufacturing time reduced from 90 minutes to 15 minutes at a cost savings per fastener of $\$ 210$. Productivity increased by 300 percent, and the shipyard estimated savings of $\$ 900,000$ annually with a three-shift operation. The experience at Portsmouth also provided a potential model for manufacturing of fasteners in other applications, such as for aircraft, nuclear reactors, and medical devices. ${ }^{75}$

As with Mare Island and Portsmouth, the Navy's RAMP program wanted automated manufacturing of spare parts. But, this Rapid Acquisition of Manufactured Parts (RAMP) project aimed to go beyond a select group of pipe connectors or fasteners to building potentially any parts needed for the operation of a vehicle in the armed services. Economics drove this desire. The Naval Supply Systems Command (NAVSUP) wanted to reduce the expense of stockpiling and warehousing a host of spare parts that may or may not be needed when ships or subs came in for maintenance and repairs. Wanting to "warehouse data, not parts," NAVSUP eyed the AMRF as a possible model for realizing its vision. Once the Bureau of Standards had successfully demonstrated its automated research facility in several early test runs, NAVSUP decided it was time to move the experimental work to a factory setting. But where? The South Carolina Research Authority (SCRA) offered an answer. Begun in 1982, this

\footnotetext{
Lee, "Computer-Controlled Fastener Workstation," 1-4; Nanzetta, "Technology Transfer," 329; Nanzetta to Ted Hicks, May 4, 1992, Smart Machining Projects, 1-2, File Nanzetta Chron File, May 1992, AMRF Files, NIST, Lee, interview, April 7, 2000; Kang Lee, The Portsmouth Fastener Workstation, draft, File Nanzetta Chron File, February 1992, AMRF Files, N1ST, Simpson, interview, 1993. Philip Nanzetta to Steve Linder, July 1, 1991, 3-4, File Nanzetta Chron File July 1991, AMRF Files, N1ST. According to the November 2000 Portsmouth Naval Shipyard website, the level 1 fastener workstation continues in use in its machine shop.
} 
cooperative venture between the state, universities, and industry set up high technology industrial parks throughout South Carolina with the goal of promoting increased employment and economic development. In 1985, NAVSUP approached SCRA authorities and Senator Strom Thurmond, then President pro tem of the Senate, with the idea of having a RAMP facility as part of SCRA. Favorable reaction led to further discussions between the Senator and the Navy, resulting the same year with the decision to have SCRA form a consortium (known as the American Manufacturing Research Consortium) to build a RAMP demonstration facility in Charleston, $\mathrm{SC}^{76}$

From the beginning, AMRF team members served as technical consultants, providing the research results which the RAMP facility would implement. RAMP plans at first practically duplicated the AMRF shop floor, intending to have Horizontal, Vertical, and Turning machining workstations, along with a quality assurance workstation (Inspection), arranged on the same floor plan as the AMRF with a robot cart shuttling between each workstation. Further consideration pointed to the need for a different floor plan to better suit RAMP's manufacturing requirements. More importantly, the AMRF team provided its extensive expertise in automated manufacturing. AMRFers reviewed RAMP technical documents, provided technical recommendations, ran special intensive demonstrations for RAMP officials, and shared software system documentation and other technical documents. Through this collaborative effort, RAMP incorporated AMRF technology in its architecture and principles for control, sensors, communications, and data handling. Albus's Hierarchical Control System determined the underlying structure for the entire control system. RAMP also used the Hierarchical Control System Emulator (HCSE) developed at the Bureau of Standards, to aid testing of the various systems. In contrast to the AMRF, RAMP used more human than robot interaction, having humans load/unload machines and conduct on-floor monitoring activities.

NOTHER SIGNIFICANT TECHNICAL COLLABORATION between the AMRF and
SCRA/RAMP projects dealt with development of a product data exchange standard. Experience with
IGES (Initial Graphics Exchange Specification) had shown the need for more sophisticated
standards to support integration of different types of product life cycle applications. IGES allowed for
data file exchange, the export of physical data points. But, people in industry and the international standards communities soon realized that they needed more flexibility than IGES offered. The geometric definition of a part changed as it is progressed through its manufacturing life cycle, from research and development through production. Having a standard maintain these changing definitions and keep all information intact and usable became increasingly important in the onslaught of the Second Industrial Revolution. PDES, standing for Product Data Exchange using STEP, and STEP, standing for Standard for the Exchange of Product Model Data, became the names designated for efforts in determining this new standard. PDES refers to activities in the United States to support development of the international standard, STEP, which is a pioneering effort to examine the research and development of the information technology needed for a shared enterprise environment. PDES and STEP offered a whole new vision for manufacturing. People could create data, store it, and exchange it, no matter what or where the data was. The data might describe such things as geometries, fit, finish, tolerances, and complete instructions for automated manufacture. The key was having PDES/STEP specifying the format and vocabulary for the data, a neutral format for the data, so that it could be

\footnotetext{
" Phil Nanzetta, "NBS Relationship with South Carolina Research Authority and the Navy's RAMP/RTIF (RAMP Test and Integration Facility) Program," August 28, 1987, 1, File Phil Nanzetta Chron File Aug 1987, AMRF Files, NIST; Nanzetta, "Technology Transfer," 316; McInnis Proposed Remarks for December 1986 demonstration; Long-Range Plan for CME, October 1984, updated for December 1986; Remarks by John Simpson to NAS Panel.

Nanzetta, "NBS Relationship with SCRA," 1-3; Lyons, interview, July 28, 2000.
} 
carried to different applications and between different vendors' software. This standard promised to reduce costs because process engineering could be done at the time of designing and because time and money spent for errorcorrecting and manual re-entry was greatly reduced. Quality increased because product fit and tolerances could be encoded into computerized specifications. Production time and inventory costs decreased thanks to the ease of manufacturing in small lot sizes. ${ }^{78}$

HE NATIONAL BUREAU OF STANDARDS chaired the PDES effort. The agency had the experience from its IGES contributions and also the hands-on recognition of the limitations of product data exchange made visible in the work on the AMRF. From this first-hand involvement, NBS officials could speak knowledgeably to SCRA representatives about the promise and importance of PDES, successfully persuading them to base their RAMP system on the emerging PDES standard. In February 1988, seven US defense contractors voted to incorporate formally into a cooperative organization to support PDES development. Other companies quickly joined PDES, Inc., which would facilitate industry involvement in developing the standard. SCRA eventually won the host contract to provide management support of PDES, Inc., raising the SCRA/RAMP level of involvement in automation issues. ${ }^{79}$

Keenly watching these developments in South Carolina, Senator Ernest F. ("Fritz") Hollings (D-SC) gained a great respect for the manufacturing activities of the National Bureau of Standards. Hollings had long been committed to increasing the manufacturing base of both his home state South Carolina and the nation. As a former governor, he had worked hard to recruit companies to locate in South Carolina. To make the state attractive, he had stressed worker training through a statewide technical college system. He emphasized to potential companies that if they built their factories in his state, they could select their workers and have them trained at state expense in these schools. Such a strategy worked, most notably when BMW chose to locate its first factory outside Germany in South Carolina. By attracting such companies, money stayed in the state and kept the economy strong. Such reasoning also colored Hollings's national perspective. The United States had to find ways to keep its manufacturing competitive. That meant helping American companies to compete against such countries as Japan and Germany. As his congressional staffer Pat Windham recalled, Hollings liked to say that "We Americans get the Nobel Prizes, the Japanese get the profits." ${ }^{80}$ Hollings saw great promise in the automated manufacturing research being conducted at the Bureau of Standards, and he took great pride that one of its most significant adaptations to help the US Navy's manufacturing capabilities sat in his home state's port, Charleston. Later, during the Gulf War of 1991, Hollings had another reason to appreciate the significance of the AMRF/RAMP technology. He had two nephews serving in the Marine Corps in separate units in the war. One nephew flew helicopters, and Hollings would remark with pride that some of the spare parts for helicopters in the Gulf were being manufactured with this technology. For years, he had supported the program while serving on the defense appropriations subcommittee, and now he could point to a real connection, helping his nephews and others in combat overseas. Such an example also demonstrated how the automation technology could be adapted from Navy needs to the entire military.

\footnotetext{
${ }^{78}$ Gary P. Carver and Howard M. Bloom, "Concurrent Engineering through Product Data Standards," in Jackson, Three Pillars of Technology, 57-59; Mitchell, interview, May 5, 2000; Bloom, interview, April 7, 2000. For a step-by-step look at the development of STEP, see Sharon J. Kemmerer, ed., STEP: The Grand Experience, NIST SP 939 (Gaithersburg, MD: NIST, 1999); Senate Committee on Commerce, Science, and Transportation, Department of Commerce Technology Programs Authorization: Hearing, 100 Cong., $1^{\text {th }}$ sess., June 6, 1989, 12, 45.

"9 Carver and Bloom, "Concurrent Engineering," 61; Dave Fusaro, "Seven Defense Contractors Incorporate PDES," Metalworking Neus (February 29, 1988), 5, 14, File B-39, John Simpson Files, MEL, NIST; Nanzetta, "Technology Transfer," 317.

${ }^{80}$ Pat Windham, interview by author, August 4, 2000, audiotape, NIST.

${ }^{81}$ Ibid.
} 


\section{Transformation}

Back in the mid-1980s, when Sen. Hollings first took notice of the AMRF and RAMP, he saw promise for American manufacturing from the automation research. Always concerned about issues of productivity and competitiveness within the global marketplace, Hollings recognized that considerable expertise lay within the Bureau of Standards. What were the best ways to tap that experience? He encouraged his aide Pat Windham to start talking with a range of people, including House Science Committee ${ }^{82}$ staffer Jim Turner and NBS's National Engineering Laboratory director John Lyons and Lyons' deputy Sam Kramer. These technical discussions, fact-finding missions, explored how the Bureau envisioned its role and what more could be done to help American industry. Windham learned that a large percentage of small shop manufacturers, who stood the most to gain from automation, had not attended the week-long AMRF demonstrations or even knew that the facility existed. According to a 1985 report by the National Research Council, such small machine shop owners believed that the AMRF was largely "too elaborate, too advanced, and fairly inappropriate for their needs." " These owners saw such advancements as Drill-Up and error mapping as useful, so long as the investment was within their reach and had fairly immediate benefits. However, for the time being, more than half of their recent capital spending had been on Japanese machine tools, which the shop owners claimed were cheaper, more reliable, more accurate, and came with better service than that of their American counterparts. The National Research Council urged the Bureau of Standards to consider an information campaign targeted at small machine shop owners as a primary means for transferring AMRF-type technology.

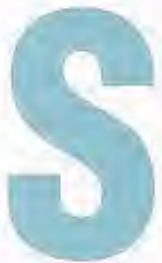

PREADING INFORMATION ABOUT AUTOMATION and other technological advancements had been a consideration both within and outside the Bureau. Back in 1979, John Simpson's group had included outreach in its grandiose proposal to then-Secretary of Commerce Phil Klutznick. ${ }^{86}$ In early 1987, a professor at the Massachusetts Institute of Technology proposed that the federal government create an industrial counterpart to the Department of Agriculture's Agricultural Extension Service, which had made tremendous inroads in helping American agricultural productivity over the years. An Industrial Extension Service would have agents assigned to specific geographical areas to disseminate up-to-date knowledge to area businesses. ${ }^{87}$ Around the same time period, Dennis Swyt, now deputy director under Simpson, had proposed that technology transfer should take the same form as how the Bureau had traditionally transferred measurement standards, in a pyramid from NBS to the states, and to the counties and cities and towns, and then to the local weights and measurements person. This model helped shape future thoughts about outreach. ${ }^{88}$ Congress soon explored this idea with the Bureau. When testifying in hearings on the fiscal year 1988 NBS authorizations, Director Ambler admitted that "we know we have this problem with small manufacturers in

\footnotetext{
: According to former NBS Director Ernest Ambler, it was very important that Pat Windham in the Senate and Jim Turner, helped by Dave Goldston and Maryanne Bach, in the House got along well and were able to get their respective committees to work together for these changes. A key Congressman was the late George Brown (R-CA); also important were Congressmen Sherwood Boehlert (R-NY), Manual Luján, Jr. (R-NM), and Doug Walgren (D-PA)

${ }^{83} \mathrm{Ibid}$; John Lyons, interview by Karma Beal, June 9, 1993, transcript, 1-4, NIST Archives; Lyons, interview, July 28, 2000.

${ }^{84}$ National Research Council, Reactions of Small Machine Shop Ouners to the Automated Manufacturing Research Facility of the National Bureau of Standards (Washington, DC: National Academy Press, 1985), 9.

${ }^{85}$ Ibid, 4, 10; Windham, interview, August 4, 2000.

${ }_{86}^{86}$ John Lyons, interview, July 28, 2000; John Lyons, interview by Karma Beal, June 1, 1993, transcript, 29, NIST Archives

37 "Boosting Productivity by Investing in Research," Wasbington Star (February 27, 1987), A-12, File B-16, John Simpson Files, MEL, NIST.

${ }^{88}$ Lyons, interview, July 28, 2000; see also "What Will a Hollings Center Look Like and How Will It Get that Way?" September 25, 1987, 7, File Phil Nanzetta Chron File, Sept 1987, AMRF Files, NIST.
} 
spades. ${ }^{, 89}$ One proposal to address this issue involved setting up a mini-AMRF, without robots or transfer workstations. Instead, the facility would have personal computers operating CAD/CAM systems and numerically controlled machine tools. Ambler thought such a set up might be "a little bit of a better touchy-feely thing, where small [machine shop owners could] come in and say, yeah, there's something I can learn from that." ${ }^{, 90}$ The fullblown AMRF had essentially intimidated and overwhelmed previous small shop manufacturers. But, more promising to Ambler was the transformation of states themselves from technologically illiterate entities (when it came to automation) as late as 1980 to sophisticated stimulators of technology less than a decade later. Ambler noted that "That's true of almost all states now. And it seems to me that what we really need to do is create an opportunity for 50 - at least 50 - intermediaries, and we are looking very carefully at what states can do and the various mechanisms, and they're very diverse." ${ }^{, 91}$ Ambler's vision for outreach through state intermediaries fit within one House bill just being offered by Congressman Sherwood Boehlert (R-NY). His bill would establish a 3year pilot program at NBS for a Technology Extension Service. ${ }^{92}$

The air about Congress and within NBS in 1987 certainly supported discussions of some sort of information campaign to help small businesses. Despite continued opposition from the Reagan White House, which fought any legislation that smacked of industrial policy, Sen. Hollings offered his own answer to technology transfer. Based on his commitment to boosting productivity and the advice provided by his aide Windham, Hollings proposed in S. 907, the Technology Competitiveness Act of 1987, to establish a series of Hollings Centers to share manufacturing technology from the AMRF to the widest possible domestic audience. These regional centers for the transfer of manufacturing technology and automation information would have close ties with industrial partners. They would also have a strong educational component to broaden the knowledge base of automation and technological advancements in general. Hollings specifically eyed the AMRF success story when presenting his proposal, stating that the bill's goal was "to transfer the basic manufacturing technology and expertise already developed at the Bureau's 'factory of the future' [as the AMRF was often called at the time] to American companies that need that expertise." ${ }^{, 3}$ Excited by the prospect of these centers, Hollings managed to obtain appropriations to start the first three before his full legislation passed, combined with the Trade Act (to thwart a certain veto by President Reagan) into the Omnibus Trade and Competitiveness Act of $1988 .{ }^{94}$

HESE THREE MANUFACTURING TECHNOLOGY CENTERS (MTCS), as they came to be known, established in January 1989, effectively blanketed a third of the lower 48 states, reaching from Michigan to Maine to Florida. The Great Lakes MTC, operated by the Cleveland Advanced Manufacturing Program (CAMP) in Cleveland, $\mathrm{OH}$, quickly established working relationships with more than 400 firms in its first year of existence, helping them with worker training, diversification of markets, and manufacturing technology. The Northeast MTC, based in Albany, NY, and run by the New York State Science and Technology Foundation and Rensselaer Polytechnic Institute, helped firms such as Unico Special Products, which produced Corian kitchen countertops, to use CAD/CAM methods in their production lines,

\footnotetext{
${ }^{89}$ House Committee on Science, Space, and Technology, Subcommittee on Science, Research and Technology, Hearing on 1988 National Bureau of Standards Autborization, $100^{\text {in }}$ Cong., $1^{\text {\$t }}$ sess., March 3, 1987, 54.

${ }^{90}$ lbid, 53 .

${ }^{91}$ Ibid, 54 .

II Ibid, 54; Phil Nanzetta to Planning Council, Hollings Bill: DOC Testimony, May 20, 1987, File Phil Nanzetta Chron File May 1987, AMRF Files, NIST.

${ }^{95}$ Hollings, as quoted in his Senate floor statement by Phil Nanzetta, "Plan for NIT implementation of Cooperative Centers for the Transfer of Research in Manufacturing," June 1987, 1, 4, File Phil Nanzetta Chron File June 1987, AMRF Files, NIST.

"Windham, interview, August 4, 2000; Senate Subcommittee of the Committee on Appropriations, Departments of Commerce, Justice, State, the Judiciary, and Related Agencies Appropriations for Fiscal Year 1989: Hearings on H. R. 4782, 100 Cong., $2^{d}$ sess., May 12, 1988, 191-92, 271-72.
} 
significantly reducing turnaround time between order and delivery. The Southeast MTC, run by the University of South Carolina in Columbia, emphasized workforce training and hands-on demonstrations of technology solutions for an array of manufacturing situations. Building on the technical college network established under Hollings's guidance as governor and the high-technology industrial parks of the South Carolina Research Authority (SCRA), the Southeast MTC established three major demonstration centers at technical colleges distributed throughout the state, further assisting technology transfer. ${ }^{95}$ For each of these first three MTCs, the non-profit agencies hosting the centers already had some mechanism for technology transfer and established partnerships with local industry, making them strong candidates for this pilot program. South Carolina did not receive favorable treatment. As NEL director John Lyons later stated, "We swore up and down that they had competed, and they did. ... We told Pat Windham that if South Carolina wants to play this game, somebody has to lean on those people down there and make them really work hard to put together the right proposal." ${ }^{, 96}$ And they did, taking advantage of the mechanisms already available in the state.

Y THE TIME OF THE 1991 CREATION of two more centers in Ann Arbor, MI, and Overland Park, KS, experience had shown the need for a basic shift in philosophy toward small shop manufacturers. Windham, based on his fact-finding discussions with John Lyons and others, had thought that the MTCs would transfer, maybe not the state-of-the-art research of the AMRF, but still some fairly sophisticated technology to the small-to-medium firms. ${ }^{97}$ In early thoughts about the initial Hollings Centers, Phil Nanzetta had noted that NBS would have to run the AMRF continuously to meet demands of the first center representatives to see and learn from its example. And though Nanzetta warned that NBS "must be careful not to sound big-headed about handing over our research results to Hollings Centers,",98 he still envisioned a center facility layout that looked similar to that of the AMRF.9. As the centers began their actual hands-on work and evaluations poured in, Nanzetta, Windham, and others quickly realized that small- and medium-sized manufacturers needed all levels of sophistication, ranging from how to pick and install a personal computer to how to diversify operations to capture an international market. The idea of "mini-AMRFs" set up around the country could not survive, and in Nanzetta's mind, would degrade the public's opinion about the AMRF. In his management of the MTC program, Nanzetta recognized that the research facility could not be handed directly to small business. Under his initial guidance, MTCs gradually focused on demonstrating the best available commercially supported technology in their facilities, allowing local companies to "try before you buy" new technologies. ${ }^{100}$

And, the MTCs produced solid financial gains for their customers, small-batch manufacturing shops. As early as 1991, individual clients posted dollar savings of $\$ 3.5$ to $\$ 4$ million in the areas of $\mathrm{CAD} / \mathrm{CAM}$ implementation and adoption of robotics. In total, within 18 months of their establishment, MTCs achieved an impact exceeding \$75 million. Further studies of client samples in 1992 indicated a 37 percent reduction in scrap

\footnotetext{
"sational Research Council, 1992 Proposal Evaluation for the Manufacturing Technology Centers Program (Washington, DC: National Academy Press, 1992), 3; "Technology Transfer Centers Established," The NAVCIM Report, no date [1989], 4-5, File Navy, AMRF Files, NIST; 1989-1990 videotape of the first three centers, AMRF Files, NIST; John Carey, "For Manufacturers, a Taste of High-Tech Medicine," Business Week (April 30, 1990), 113.

Lyons, interview, July 28, 2000.

Windharn, interview, August 4, 2000 .

"What Will a Hollings Center Look Like?" 10.

Ibid, 9 .

(10n Nanzetta, interview, February 20, 2000; Windham, interview, August 4, 2000; NRC, 1992 Proposal Evaluation, 3. Phil Nanzetta to Beverly Fleisher, Points for Sam Kramer's Visiting Committee Presentation, March 5, 1992, 2, File Nanzetta Chron File, March 1992; Nanzetta, NIST Position on GAO Report on MTC Program, February 3, 1992, File Nanzetta Chron File, February 1992, both in AMRF Files, NIST.
} 
and a 34 percent increase in sales. Exports jumped an amazing 140 percent and employment increased 15 percent. Productivity, what had long driven the AMRF, jumped 7 percent in the MTC client sample, well above the mere 1 percent average national increase. The MTCs reportedly helped save an estimated $\$ 139$ million through improved client operations. Other signs of the program working could be found in the commitment of various organizations and agencies to MTC growth. The Department of Labor provided funding to develop a workforce training program while the Small Business Administration agreed to increase loan guarantees to MTC client firms. This success foreshadowed the boom during the Clinton administration when in fiscal year 1994, the newly named Manufacturing Extension Partnership (MEP) received a 79 percent budget increase, funding what would become in 1996 the national network of manufacturing modernization initiatives. ${ }^{101}$

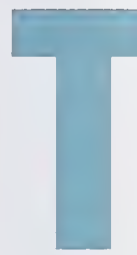

HE AMRF EXAMPLE did more than get Sen. Hollings thinking of technology transfer through his regional Manufacturing Technology Centers. The AMRF also focused attention on the manufacturing competence of the Bureau of Standards and set the agency apart as a leader in helping industry. Congress looked at the AMRF and the Bureau and saw the Navy and big companies like GM and Boeing dedicating money, time, and other resources to the manufacturing research. Talks across the country to industry by CME Deputy Director Dennis Swyt helped increase the AMRF's visibility and built larger circles of support. Windham later stated that such support had a big political impact. And, Hollings and others wanted to build on that expertise, extend its reach to help as much of American industry as possible. But, the NBS Organic Act of 1901 failed to reflect these increasing concerns in competitiveness and manufacturing. So, when Congress passed the Omnibus Trade and Competitiveness Act of 1988, it also updated the NBS organic act. This updating added the MTC program to help small businesses and also established the Advanced Technology Program, to speed up commercialization of promising new technological ideas from universities, industry, and the government. To emphasize these new technology-based programs, Congress changed the Bureau's name to the National Institute of Standards and Technology. ${ }^{102}$

Few at the venerable National Bureau of Standards liked the name change. NBS had a long history of service to the scientific, technical, and industrial communities of the country and the new name seemed to strip this past away. ${ }^{103}$ Yet, as Windham had learned, the old name failed to reflect the agency's identity. This fact became clear to him back in 1984, when Windham was heading in a subway car under the Senate office buildings to the Capitol. He was working on an NBS authorization bill. Sen. Pete Domenici (D-NM) was in the car and asked Windham what he was working on. Windham told him he was working on a bill for the National Bureau of Standards, and Sen. Domenici looked at him quizzically and asked, "What's that?" In Windham's mind, Domenici was one of the most sophisticated senators on science and technology issues, and if he didn't know what NBS was, then that was unfortunate. Furthermore, to Windham, having the word "Standards" in its name added to confusion about its identity — did this mean physical standards, voluntary product standards, or regulatory standards? Yes to the first two possibilities, but a definite no to the last one, adding to the confusion. "I'm not at all presumptuous enough to say," Windham recalled, "that I personally had a right to recommend to

\footnotetext{
${ }^{101}$ Phil Nanzetta, "Manufacturing Technology Centers," May 17, 1991, File Phil Nanzetta Chron File May 1991, AMRF Files, NIST; Phil Nanzetta to Joyce Brown, Don Johnson, October 6, 1992, File Nanzetta Chron File October 1992, AMRF Files, NIST; Phil to All MEP, VCAT on MEP, January 5 , 1994, black binder, AMRF Files, NIST; NRC, 1992 Proposal Evaluation, 3.

${ }^{100}$ Windham, interview, August 4, 2000; Swyt, interview, March 10, 2000; Eitzen, personal communication, January 28, 2001; P. L. 100-418, Ommibus Trade and Competitiveness Act of 1988: it is the purpose of this act to "modernize and restructure that agency to augment its unique ability to enhance the competitiveness of American industry while maintaining its traditional function. . ."

${ }^{103}$ This sentiment was almost universally expressed during interviews for this project. See, for example, Lyons, interview, July 28, 2000; Nanzetta, interview, February 20, 2000; Bloom, interview, March 3, 2000
} 
my boss [Sen. Hollings] that we go change an agency's name just for the heck of it." ${ }^{104}$ But, in updating the organic act, Windham did suggest that a name change would help the public focus on the meaning and mission of the agency.

NIST was not the first choice. Windham volunteered the name National Institute of Technology (NIT), which Hollings put in S. 907. However, House Science Committee staffer Jim Turner pointed out, in response to legitimate concerns raised by NBS officials, that "Standards" should remain as part of the name. Turner argued that NBS might not mean much to the general public, but it meant a great deal to the scientific, technical, and industrial communities. If "Standards" was dropped from the name, these groups would wonder if the new agency would continue to serve their needs. After much discussion, Congress adopted NIST as the new name. As Nanzetta remembered, Hollings used this new name for the first time at the ground-breaking ceremonies for the RAMP facility in Charleston. The new agency, NIST, had its foundation formed from the lasting impact of the Automated Manufacturing Research Facility and its dancing robots and whirling machine tools. ${ }^{105}$

\footnotetext{
${ }^{104}$ Windham, interview, August 4, 2000.

${ }^{105}$ Windham, interview, August 4, 2000; Nanzetta, interview, February 20, 2000; Nanzetta, "Technology Transfer," 317.
} 


\section{Chapter Five}

\section{LEGACY}

HE AMRF DEMONSTRATED through its fifteen years of existence that partnerships among government, academia, and industry advance technological innovations and aid economic development. When officially closed in 1995, the AMRF could count an array of accomplishments. Its scientists authored 20 patents on such technologies for robots as grippers, quick change wrists, end effectors, image processors, and special magnet-resistive skin and innovations for machine tools, including laser interferometer tracking devices, in-line measurement devices, tool wear monitors, and cutting tool measurement apparati. Another 20 standards or standard proposals promised seamless interfacing between computers and the "muscled" peripherals, whether they be dancing robots, whirling machine tools, inspection stations, storage systems, or other manufacturing machinery. More than 25 companies and non-profit organizations or universities developed specific products or subsystems from AMRF technology. Twice that many firms benefitted from the collaborative investigative environment at NBS/NIST through the Industrial Research Associates program. ${ }^{1}$ More companies gained valuable knowledge and guidance through the various technology transfer programs put in place thanks to the AMRF example: RAMP for Navy and other military suppliers and the Manufacturing Technology Centers, which grew from the initial three centers in 1989 to an amazing 400 locations throughout the United States and Puerto Rico by 1996. The Advanced Technology Program, which came into existence thanks to the AMRF-inspired thinking about high technology at NBS/NIST, helped speed commercialization of specific technologies through more partnerships between government and outside firms or institutions. $^{2}$

And, these initiatives and technologies could not have been done to this extent anywhere else but in a government facility. "Government has to help," as one small machine shop owner remarked after getting critical assistance in CAD/CAM from NIST and the Northeast MTC. More people from small-batch firms shared this view over the course of the AMRF's existence. Jim Brimson, Vice President of Business Development at Computer Aided Manufacturing International stated that "we need the critical mass and focus provided at the AMRF. It is found nowhere else." Businesses had to focus on the daily requirements of meeting customer demands while the AMRF could act as a forum for people in industry, government, and academia, bringing the best together to work on the long-range problems affecting all of manufacturing. The AMRF also looked out for the small-batch manufacturers, who collectively held the balance of trade but individually failed to attract much notice until the crisis in international competition. ${ }^{5}$ In the eyes of Richard Hook, Manager of Research and Development at Brown \& Sharpe machine tool company, "The AMRF facility is an excellent use of our tax dollars. The work they are doing is needed to achieve the levels of productivity we will require to compete with Japan., ${ }^{16}$ This need for

\footnotetext{
'Nanzetta, “Technology Transfer," 312-14, 322.

Windham, interview, August 4, 2000.

3 Dominick Martorana of Highland Manufacturing Inc., as quoted by John Carey, "For Manufacturers, A Taste of High-Tech Medicine," Business Week (April 30, 1990), 113 .

' Jim Brimson, as quoted by Meade, The NBS' AMRF, 33.

Meade, The NBS' AMRF, 32, 33, 35, 37.

Richard Hook, as quoted in Ibid, 33.
} 
government intervention contrasted sharply with what the Reagan and then Bush administrations felt was best left to industry. Yet, a 1992 National Academy of Engineering and National Academy of Sciences report countered this view, stating unequivocally that government investment in American technology was necessary to keep American industry competitive and the American economy strong.

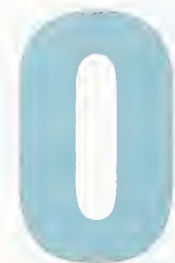

NE EXAMPLE of how the AMRF government program directly helped American competitiveness comes from Texas Instruments. Mark Luce first came to then-NBS in 1986 as a guest researcher from Texas Instruments. TI had never before taken advantage of the opportunities for research and technology advancement offered by the Bureau of Standards, but news of the AMRF had piqued the company's interest. Could a relationship with this manufacturing research laboratory help TI automate one of its production lines and save it money while increasing productivity? Luce and two other guest researchers who followed him in this task reported a resounding yes. Working with the Vertical Workstation crew of Chuck McLean, Steve Ray, Pete Brown, and others, Luce helped further develop the automated process planning system that the team had first demonstrated in 1985. By applying his engineering and manufacturing experience in $\mathrm{CAD} / \mathrm{CAM}$, design production, and installation and management expertise in metal fabrication systems at Texas Instruments, Luce helped to develop an artificial intelligence (AI)-based planning system and supporting knowledge base. The workstation controller drew upon this knowledge base to define the cutting processes, types of tools, and cutting speeds for producing an array of parts. ${ }^{8}$

Although impressive, this knowledge base for the AMRF's Vertical Workstation still only made fairly simple angle brackets or other straightforward parts. Luce and other visitors from machining shops wanted assurances that the design and development showcased in the AMRF could be hardened and transferred to real-world industry manufacturing. Luce proved that it did have that promise. According to the agreement with NBS/NIST, Luce took the system back to his company and further developed it there. Other researchers from other companies could also take the algorithm or method; Texas Instruments only retained the specific knowledge about machining processes or tools which it had uniquely contributed. Once he went back to TI, Luce worked with a team of five people to integrate the knowledge base with some off-the-shelf systems for programming, planning, and designing of parts. They also interfaced the expanded system with a newly released solid modeling program, expanding the original knowledge base into what they called a "manufacturing advisor" system. They then installed the enhanced system into a 1200-person metal fabrication facility for use by all the planners, programmers, and manufacturing engineers. They came to an interesting result. The new system aided productivity by reducing planning time. But, it also determined the most cost effective alternatives for machining. Previously, TI had relied on its engineers referring to an elaborate database of equipment and tools for determining machining processes. But, the company discovered during a survey that its planners only used about 25 percent of this elaborate database about 90 percent of the time. People had become somewhat complacent about using certain kinds of equipment and had not explored alternatives. The advisor system broadened the possibilities for machining while taking into account productivity and economics. ${ }^{9}$

This AMRF-based system continues in use at Texas Instruments, a concrete example of the benefits of government-industry participation. As Luce later stated, "the technology developed here within the AMRF was directly transferred to TI, was expanded and developed over time and created a significant benefit for the

\footnotetext{
National Academy of Engineering and National Academy of Sciences report, 1992, as described by Senator Hollings, Senate Committee on Commerce, Science, and Transportation, Government Role in Civilian Technology: Hearing, 102d Cong., 2d sess., March 26, 1992, 2.

Luce, interview, June 2, 2000.

Ibid.
} 
manufacturing and engineering part of one of the facilities." ${ }^{\text {"10 }}$ Luce fondly recalls his guest-researcher days at NBS/NIST, calling the experience one of the most rewarding ones of his career. Very positive dynamics began almost immediately, with Luce treated just like the rest of the research staff, participating in many of the decision-making activities and design meetings. He brought his hands-on work experience and on-the-floormanufacturing expertise, pushing the AMRF scientists to put realistic industry knowledge and expectations into their development systems. His teasing about the simple parts produced in the Vertical Workstation led his team members to present him with an aluminum cup machined from a solid blank. "Well, the cup was made so badly," Luce recalled, "that even if you drank out of it, you would cut your mouth. It was made in jest, but it was a little more complex because of what they had to do to it." Luce appreciated the attempt and, even more, enjoyed his time working on the AMRF so much that when an opportunity came, he later accepted a position at NIST and stayed, transferring his manufacturing knowledge to other projects.

Other examples of direct benefits to industry abound. James Albus's hierarchical control model became, according to two professors at the Robotics Institute of Carnegie Mellon University, the most popular architecture for factory control systems. ${ }^{12}$ David Godfrey remembered in the early 1980s that he stumbled through a process of implementing a hierarchical control system for about 100 machines at General Electric. That experience demonstrated to him that "the solution articulated by NBS is the answer. Their answer is right on target. Their approach is right and will help me move faster in the future." ${ }^{, 13}$ Gus Goldshine, Director of Advanced Manufacturing Engineering for General Dynamics' Pomona Division, noted in 1984 that this integrated model allowed "a control structure to achieve, for the first time, control of all machines." ${ }^{14}$ But the real beauty from industry's viewpoint came from the realization that the AMRF control architecture could be "applied to other areas of business. If it works in a machine shop in real time, it can be applied in other areas." ${ }^{, 15}$ Tony Barbera, who first left the AMRF in 1986 to apply the hierarchical control architecture and real-time control system to Martin Marietta's operations, eventually joined a small company to promote the use of this idea. "The whole control methodology," he later stated, "I still believe is one of the most important contributions we ever made. The way of partitioning a large control system, like a factory control system, in that manner so that interfaces could be defined and the standardized architecture could be built, is of tremendous benefit, it really is."

AMRF research in software error correction for both coordinate measuring machines (CMM) and machine tools also directly influenced industry with successful results. In the early 1980s, Brown \& Sharpe first implemented three-dimensional error correction in its Validator series of CMMs. Later, they added linear and axial error correction capabilities. By the mid-1980s, Giddings \& Lewis Measurement Systems had also adopted error correction in its Apollo line of CMMs, providing a higher precision machine for less cost but with speed, accuracy, and volume capabilities surpassing those of traditional measuring machines. ${ }^{17}$ As John Bosch, Vice President and General Manager of the then-named Sheffield Division of Warner \& Swasey (later Giddings \&

\footnotetext{
${ }^{10}$ Ibid.

Ibid.

"2 Paul Kenneth Wright and David Alan Bourne, Manufacturing Intelligence (Reading, MS: Addison-Wesley Publishing Company, Inc., 1988), 82.

3 Godfrey, as quoted in Meade, The NBS' AMRF, 38.

Goldshine, as quoted in Ibid, 36 .

Goldshine, as quoted in Ibid, 37. Boeing, General Electric, and other firms all reported using the AMRF systems architecture for their individual operations, as indicated in John Meyer, Albert Jones, and Cheryl Albus, Automated Manufacturing Research Facility 1993 Annual Report (Gaithersburg, MiD: NIST, 1993), 34-35.

Barbera, interview, May 22, 2000.

"Meyer, Jones, Albus, 1993 AMRF Annual Report, 38; Phil Nanzetta, Examples of Transfer of AMRF-Developed Technology to US Industry and Government Agencies, January 14, 1991, 1, File Phil Nanzetta Chron File, January 1991, AMRF Files, NIST.
} 
Lewis), stated, "The error correction through software is revolutionary and its genesis came from the National Bureau of Standards' Automated Manufacturing Research Facility." ${ }^{18}$ By the late 1980s, Giddings \& Lewis had incorporated an enhanced version of software and laser accuracy enhancement in its Summit line of CMMs. Bosch attributed this technology to his company's ability to hold American markets and gain promising overseas business. General Motors bought six of these machines to use in its Saturn automotive power train plant "to meet their stringent quality and productivity goals.",19

As Bob Hocken and John Simpson had initially envisioned back in the late 1970s, error correction moved from coordinate measuring machines to machine tools, realizing the dream of deterministic metrology, of measuring the machining parameters to produce a part right the first time. One of the first commercial thermalerror compensated machine tools came out of Saginaw Machine Systems. With the help of an Advanced Technology Program (ATP) grant, Saginaw worked with the University of Michigan and the AMRF's Alkan Donmez to develop a machine tool that compensated for temperature deformations. ${ }^{20}$ More machine tool companies, including some in Japan and Germany, now offer such error compensation capabilities. As Donmez noted, "That wasn't there before the AMRF. Nobody is surprised anymore when they see a machine [tool company] that advertises its compensation abilities. Before AMRF days, you wouldn't see any machine tool with that kind of capability." Economics drove these technological advancements. As Kang Lee, leader of the advanced turning center operation, stated, software error correction improved machine tool accuracy by a factor of ten at a cost of only a few thousand to $\$ 10,000$. Such numbers put American machine tool manufacturers back on the map, able to compete against the more accurate (and more expensive) foreign machine tools. ${ }^{22}$

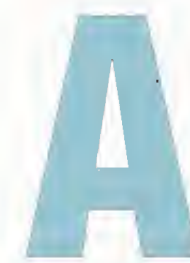

NOTHER LARGE AREA OF INFLUENCE resulting from the AMRF came from interface standards. These efforts helped cross manufacturer and product-type boundaries to build the integrated factory floor embodied in the AMRF. One example aided machine tool manufacturers. By talking with industry and national organizations such as the Machine Tool Builders Association, NBS/NIST representatives, including Donmez, identified a need for a standard to characterize machine tools. Donmez and others used the participatory methods proven by Roger Nagel in developing IGES to create a standard, approved in 1992, for performance evaluations of machining centers. Another standard came out in 1999 for characterizing turning centers. ${ }^{23}$ Work on PDES/STEP has promised further benefits for industry. AMRF interactions with industry and experience shared from developing IGES helped build an understanding about the limitations of electronic transfer of product data. Plus, implementation through RAMP, an AMRFoffshoot, further wedded the successes of the AMRF to the emergence of STEP. As NIST director Ray Kammer noted, "STEP would not have existed without the AMRF.," From STEP, the United States is positioned, according to former Senate staffer Pat Windham, to take the lead in an entirely new manufacturing infrastructure based on

\footnotetext{
${ }^{18}$ John Bosch, as quoted in Nanzetta, "Technology Transfer," 320.

${ }^{19}$ John Bosch, as quoted in 1991 Poster, AMRF Exhibit Production Materials, AMRF Files, NIST.

${ }^{20}$ Meyer, Jones, Albus, 1993 AMRF Annual Report, 38; Phil Nanzetta, Report on Trip to Saginaw Machine Systems, Detroit, April 21, 1991, File Nanzetta Chron File April 1991, AMRF Files, NIST.

Donmez, interview, May 12, 2000.

${ }^{22}$ Lee, interview, April 7, 2000. In the interview, Lee mentioned that based on the sensor integration work of the AMRF's Turning Workstation, the Mare Island Flexible Manufacturing Workstation, and the Portsmouth Fastener Workstation, he recognized the need for a sensor interface standard for networking sensors. Based on this experience, he led an IEEE Committee on Sensor Technology and developed an industry-smart transducer interface standard for sensors and actuators.

${ }^{23}$ Donmez, interview, May 12, 2000.

${ }^{24}$ Kammer, interview, June 16, 2000.
} 
electronic transmission of information. "That's an enormous competitive advantage for the United States," according to Windham. They saw this incredible potential back in 1989. "It was all based on the kind of electronic integration that came out of the AMRF project and the RAMP implementation of it. . . If we do go to web-based manufacturing, such as ordering, specification, and design, we will have the AMRF and the related projects to thank for it.",25

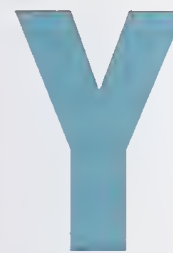

ET, THE AMRF DID NOT ACHIEVE ITS HOLY GRAlL. Even with all of these interface standards, companies still cannot simply plug multiple computer, machine tool, and robot systems together without some additional programming work. The vision of a hifi stereo system remains down the road. The AMRF provided the initial steps toward that end result, but, as Howard Bloom, now acting director of the Manufacturing Engineering Laboratory (which replaced the Center for Manufacturing Engineering in 1991) stated, "We were way ahead of our time. . . The world wasn't ready." For Bloom, if the AMRF had remained as a stable integrated factory after the 1986 full demonstration, progress might have been made. Experimentation on factory-wide integration might have produced the needed additional standards. But, in some ways, the goal was not reasonable. As Albus, the robotics man, later reflected, "The goal now ... would be to increase the productivity of the workers. Let the human do what the human does best and let the machine do what the machine does best." ${ }^{, 27}$ Former AMRF program manager Phil Nanzetta echoed this thought, stating that the idea of a total lights-out factory was "not a good model. The best model is one that has automation where automation makes sense but people where people can do the job better than automation can do the job, a much more hybrid view .... Y You would have a combination of people, computers, and manipulators do things.",28

Companies and the AMRF's major sponsor Navy ManTech realized the limitations of a totally automated factory model and pushed the AMRF toward more limited integration issues which still had great economic opportunities. A lights-out factory required incredible financial resources, in the millions of dollars, to buy, install, control, and maintain. Costs never went down so that the smaller firms could afford these cells and make total automation pervasive. Steve Linder, who replaced Jack McInnis as Navy ManTech director, stated, "There had been a lot of focus in companies where they installed robots on line because that's what they saw the Japanese doing. It was quickly discovered that's not necessarily the way you need to go." ${ }^{, 29}$ An alternative vision appeared that AMRF researchers did pursue during the post-1986 period: computer integrated manufacturing (CIM). CIM highlighted integration of a different sort. Manufacturers might buy a few automated pieces and hook them together, integrating the hardware to make products. But, these same manufacturers demanded communication between those shop-floor systems and office software systems. How do companies schedule design, engineering, purchasing, and machining together? CIM explored these facets, and former AMRF researchers, many of them joined under MEL's Manufacturing Systems Integration Division (MSID), which replaced Howard Bloom's former Factory Automated Systems Division, were in the forefront of developing this

\footnotetext{
${ }^{25}$ Windham, interview, August 4, 2000.

${ }^{26}$ Bloom, interview, April 7, 2000.

${ }^{27}$ Albus, interview, February 25, 2000.

${ }^{23}$ Nanzetta, interview, February 20, 2000.

${ }^{29}$ Linder, interview, June 23, 2000.
} 
new tighter integration vision. This CIM view of total software system integration became the focus in the 1990s of how Information Technology (IT) could benefit manufacturing. ${ }^{30}$

Computer integrated manufacturing allowed manufacturers to use what was their most important asset: information. As analyst Thomas Gunn wrote in 1987, "Many companies are beginning to realize that they are really in the software business, not in the hardware business. ... What differentiates the value of these products to customers is the sophistication of the software that lies behind the operation of the total . . system.. ${ }^{, 31}$ Instead of the tight vertical integration that characterized many companies in the 1970s and 1980s, many companies began manufacturing or assembling offshore. They coordinated with suppliers and searched overseas for ways to save money through cheap labor or lower cost raw materials. MSID researcher Al Jones, who served as deputy program manager for the AMRF from the mid-1980s to near its end, noted that "the thing a company maintains and retains is knowledge and information and that's what they deem to be important." 32 The critical question for companies became how much information should they give up to their suppliers. Too much knowledge put the supplier into the position of self-sufficiency, leaving the original company struggling to reassert its command on its particular products. From the AMRF full facility days of dancing robots and whirling machine tools, emphasis then went to integration and sharing of the critical information a company needs to survive in a truly global marketplace. Without the AMRF example and its examination of this shift in manufacturing, these questions might have taken a bit longer to determine and a bit longer to decipher, jeopardizing any competitive advantage United States firms might have obtained.

O, WHAT DID THE AMRF LOOK LIKE from the late 1980s to its 1995 closing? First, the original workstations slowly became obsolete technologically and were removed to make room for new research avenues. Some of these included the Advanced Deburring and Chamfering System (ADACS), which sat next to its predecessor the Cleaning and Deburring Station, or the Mare Island and later Portsmouth Fastener Workstations, which replaced the original Turning and Horizontal Workstations. The Quality in Automation project explored software error correction, moving into temperature control and other more advanced sensors. New AMRF projects included the Composites Workstation and the Molecular Measuring Machine ( $\left.\mathrm{M}^{3}\right)$. The Composites Fabrication Workstation developed improvements in the automated fabrication of composite components through the application of advanced sensor and Real-time Control System techniques. Working with industry and the Northeast Manufacturing Technology Center (MTC), AMRF scientists used a part's geometry to determine composite fiber placement on a mandrel, representing the shape of the final part. The workstation automatically generated the robot and mandrel motions for layering the filaments while machine vision and fiber tension measurement sensors monitored and adjusted fiber placement. This workstation successfully tested the NBS/NIST position that AMRF technology could be applied to non-chipforming metal removal manufacturing, indicating the breadth of its basic principles. ${ }^{33}$

\footnotetext{
Jones, interview, May 19, 2000. The AMRF Long Range Plan, dated July 23, 1986, discusses the emergence of CIM as an AMRF research priority. The plan defines computer integrated manufacturing as "the computerization and integration of the entire manufacturing process from product conception through detailed design, manufacturing, marketing, servicing, inventory, etc., and final obsolescence, including the feedback of information from each of these multitude of steps through the complete process for both product improvement and configuration control." See Research Directions for the Automated Manufacturing Research Facility Long Range Plan, July 23, 1986, 2, included in the NBS Packet for National Academy of Sciences Panel for CME, December 17-18, 1986, File J-140, John Simpson's Files, MEL, NIST.

Thomas G. Gunn, Manufacturing for Competitive Advantage: Becoming a World Class Manufacturer (Cambridge, MA: Ballinger Publishing Company, 1987), 5 .

Jones, interview, May 19, 2000.

Technology Transfer to and from the AMRF section of July 1986 Long Range Plan; "AMRF Developing Composites Workstation," The NAVCIM Report, no date [1990], 5, File Navy 1990s, AMRF Files, NIST; AMRF: Research Activities, included in NIST, Packet for NAS Panel Review of MEL, March 5-7,
} 
N ANOTHER NEW PROJECT, AMRF scientists Clayton Teague and members of the Molecular Measuring Machine $\left(\mathrm{M}^{3}\right)$ team investigated applying some of the vibration isolation approaches being developed for this instrument to measure and control vibrations the Navy needed for achieving required quietness levels in its submarines. While most scanning tunneling microscopes relied on passive devices such as springs and eddy current dampers to control vibrations from environmental effects in small samples (100 micrometers x 100 micrometers), the larger samples to be mapped by $\mathrm{M}^{3}(50 \mathrm{~mm} \times 50 \mathrm{~mm}$ ) required longer range slideways and larger overall mechanical supporting structures. These larger structures made $M^{3}$ more susceptible to environmental effects and thus required more extensive efforts to achieve the necessary vibration isolation. Provisions were therefore incorporated into the mechanical design of $\mathrm{M}^{3}$ for a stage of active vibration control for all six degrees of freedom of the internal core of the instrument. The goal of this stage of active vibration isolation was to isolate and damp internally and externally generated vibrations to result in accelerations of the internal core structure of less than $0.01 \mathrm{~m} / \mathrm{s}^{2}$ over the range of $\mathrm{MHz}$ to $10 \mathrm{~Hz}$. The principal goal of this project was to apply the general active vibration concepts being developed for $\mathrm{M}^{3}$ to isolating components in submarines and to improvements in precision machining. Regretfully, full implementation of the concepts of $\Lambda^{3}$ and in Navy applications were not achieved because of changes in project funding from both NIST and the Nary. ${ }^{34}$

Second, AMRF management changed, giving another face to the overall project. Program manager Phil Nanzetta took his responsibilities for overseeing the AMRF with him when he moved in early 1992 to the Office of Manufacturing Programs and directed the expansion of the Manufacturing Technology Centers into the $\$ 100$ million Manufacturing Engineering Partnership (MEP). Al Jones continued to serve as his deputy and kept track of the daily activities of the research facility. By 1993, Nanzetta had been named director of MEP, and John Meyer, an independent consultant who had recently joined NIST, was named the new AMRF program manager. Jones continued to serve under Meyer. The same year, the Nary sponsor began requiring its review and approval of all technical projects done under the AMRF name. Previously, MEL had selected projects internally and then reported them to the Navy. Many in MEL did not enthusiastically accept this loss of autonomy. ${ }^{35}$ Meyer dealt with this situation by using a business-oriented approach of selling pieces of work as opposed to selling an entire program, as Nanzetta had done. Meyer required AMRF scientists to produce glitzy end-of-the-year research reports, which he then used to market AMRF projects to other potential sponsors. Meyer's consulting background helped shape a new perspective within the AMRF and MEL more generally. As Jones later recalled, Meyer "treated this more like we had customers that we had to satisfy and that we needed to look out from a strategic perspective and look around and see what things we could do and what kinds of things customers might be willing to pay for and try to match up our capabilities with what they wanted.".36

The marketing and customer-oriented focus has since become more prominent across all of MEL and even NIST, out of economic and political necessity. The AMRF catalyzed the creation of NIST and with that creation brought much greater visibility and money to the once quiet institution. As former NIST director John Lyons

1991, File NAS Reviews, AMRF Files, NIST; Phil Nanzetta, Statement of Work, Navy Center of Excellence in Automated Manufacturing, February 4, 1992,

4, File Nanzetta Chron File February 1992, AMRF Files, NIST.

${ }^{4}$ Nanzetta, February 1992 Statement of Work, Navy Center of Excellence, 5; Meyer, Jones, Albus, 1993 AMRF Annual Report, 18, 43; Clayton Teague, personal communication to Joan Wellington and author, January 22, 2001.

Philip Nanzetta Office of Manufacturing Programs section of 1991 Packet for NAS Panel Review of MEL; Phil Nanzetta to John Simpson, March 24, 1993, AMRF in Transition, File Nanzetta Chron File March 1993, AMRF Files, NIST; David C. Stieren, "A Plan to Transition the Automated

Manufacturing Research Facility at the National Institute of Standards and Technology into Future Operations," draft, March 1995, (MA thesis,

University of Maryland University College, 1995), 18, used with permission; David Stieren, "The AVRF Status and Recommendations: MEL Planning

Council Meeting," March 7,1995, slide "Significant Contributors to AMRF Present Status," white binder, AMRF Files, NIST.

Jones, interview, May 19, 2000. 
noted, "Without the AMRF, we would still be NBS. One thing was it lifted the visibility of the institution in the eyes of key people. There are good things and bad things about that but I believe the budget of this institution for the past seven years has prospered and it's very much because of the AMRF's success." ${ }^{37}$ With more heads turned towards its activities, all divisions within NIST have had to consider the outside perspective.

HAT OUTSIDE PERSPECTIVE had driven the original establishment and phenomenal growth of the AMRF and directed the next stage for the project. Albus, Hocken, Young, and Simpson had recognized the changing face of manufacturing in the 1970s and promoted the idea of computers, robots, and machine tools working together in arfful combinations. Then, Albus, Hocken, and Simpson found a willing and supportive sponsor in the Navy, who knew that its fleet of ships and submarines needed the technological capabilities and interface standards promised by the AMRF to stay afloat. By 1994, those advancements had been delivered, and the Manufacturing Engineering Laboratory had completed the work of the AMRF. New challenges faced manufacturing and the world of business more generally. The Navy responded by shifting its support to other collaborative projects within NIST, releasing only a partial amount of its fiscal year 1994 AMRF funding in the third quarter of that year. The following year, the Navy failed to include the AMRF in its budget appropriations, effectively ending the program's status as a Navy Center of Excellence. Linder later explained that the Navy "wanted to come to some type of a conclusion with the effort out there. The AMRF had produced a lot of good product." He went on to say that "It would be hard for me to estimate the return on investments but I would definitely say that the dollars that were invested out at NIST on the AMRF have paid themselves back many many times to the Navy, DOD [Department of Defense], and the nation in terms of the technology that was made available." ${ }^{38}$ But, from the Navy's perspective, it was time to move on.

This loss of Navy money did not leave MEL struggling for financial resources. Thanks to the raised visibility of NIST and the foresight of its directors in the 1990s, MEL had increased its internal money even as the Navy had decreased its contributions. With this increased flexibility, MEL management sought outside input to determine its next course of action. In several workshops with a range of manufacturers and other industry representatives, Information Technology (IT) research shined as the single most important concern for the twenty-first century. Broadly defined, IT involves any use of digital information, for example the sharing of documents over a computer network. Thanks in part to the work of the AMRF and the Manufacturing Extension Partnership, companies had embraced the promise of computers in all aspects of their production, accounting, and distribution. Yet, they soon encountered a new set of difficulties: the inability to adapt software to changing circumstances, incompatible database file formats which resulted in redundant inputting and out-of-date information, lack of interoperability among hardware and software, and high costs for contractor services to integrate these differing systems. ${ }^{39}$ Companies still recognized that computers and IT offered many benefits that would aid in global competitiveness and technological innovations, but they needed help. And so, MEL stepped in with the NAMT, the National Advanced Manufacturing Testbed as both a follow-on to the AMRF and as a positive next step to address its customers in industry. ${ }^{40}$

The NAMT provided a state-of-the-art high-speed computing and communications infrastructure to help United States industry with the latest challenges in manufacturing. Its focus on the measurements and standards

\footnotetext{
${ }^{37}$ Lyons, interview, July 28, 2000.

${ }^{38}$ Linder, interview, June 23, 2000.

${ }^{39}$ NAMT: Tourard $21^{4}$ Century Information-Based Manufacturing, NIST Special Publication 913 (Washington, DC: GPO, 1997), 4.

${ }^{40} \mathrm{Ibid}$, 2; personal communication to author, Richard H. F. Jackson, December 29, 2000.
} 


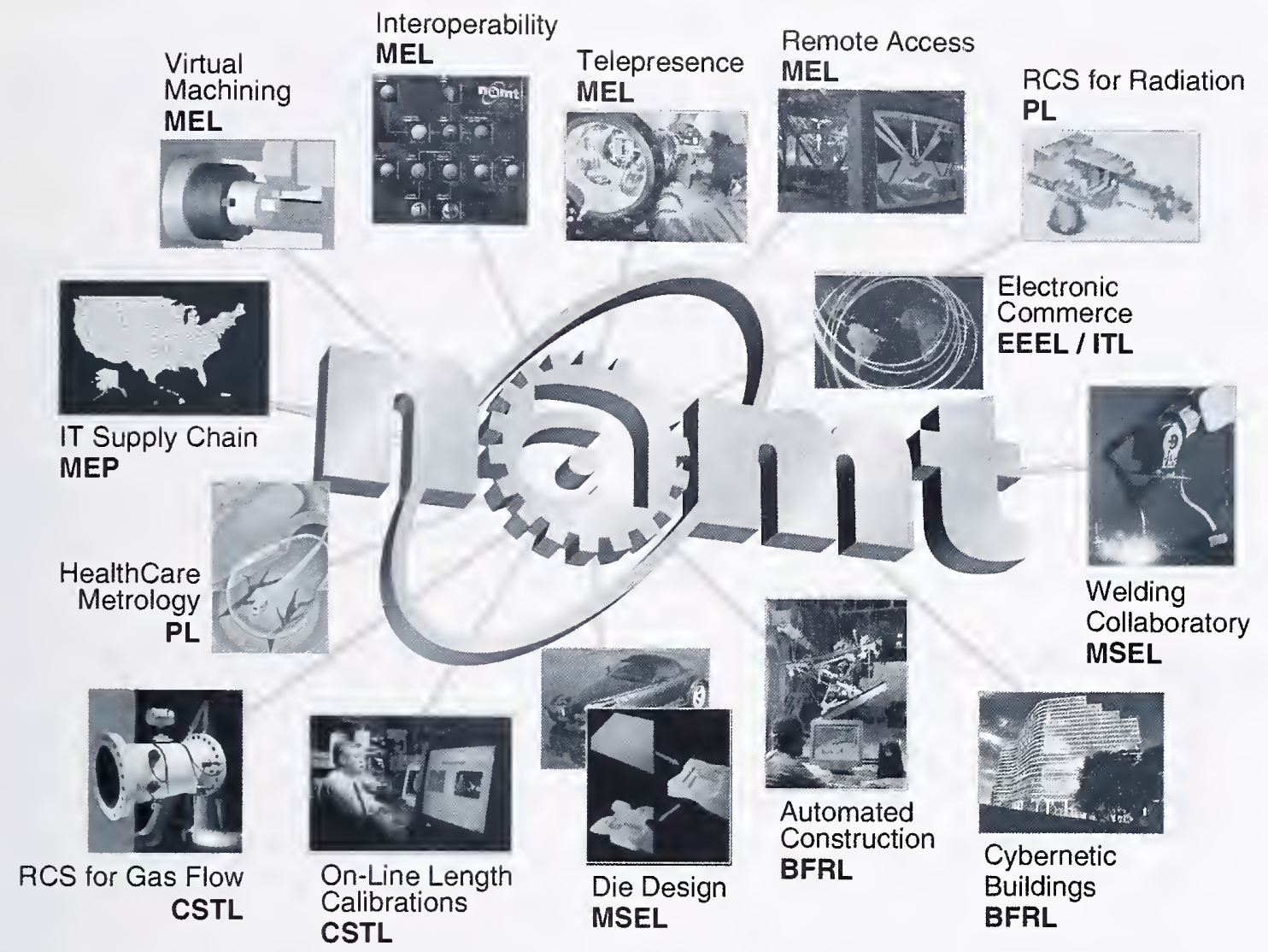

Figure 25. The National Advanced Manufacturing Testbed (NAMT) supported a range of projects throughout NIST and made Information Technology a key ingredient to serving manufacturers and other NIST customers. (MEL Office, NIST)

needed for distributed, information-based manufacturing meant that the problems of integrating new equipment or processes into existing operations and systems could be addressed. More importantly, new avenues for collaboration among companies, government, and academia were possible. These collaborations ensured that standards were developed within a shared environment of communication, an essential component for their success. Collaborative projects also built on and enhanced the value of IT, with its use of connections to find useful links among applications, resources, and facilities throughout a given sector of industry or the government. Taking full advantage of the promise of IT, NAMT projects dissolved geographical boundaries by connecting dispersed people, resources, and capabilities. Without leaving their home facilities, NAMT collaborators accessed, for example, NIST's hexapod machine tool or shared data and software tools from fellow partners in other sites. They could even teleoperate remotely located physical devices or use multimedia capabilities to interact directly across electronic linkages. ${ }^{41}$

Just as the AMRF had profoundly influenced the vision and visibility of its home institution NBS/NIST, the NAMT also has left an indelible mark on NIST. As former MEL director Richard H. F. Jackson proudly stated about NAMT's impact, "one can find the beneficial aspects of IT in everything NIST does." ${ }^{\text {"42 }}$ Through NAMT"s work in IT and the expanded capabilities of the Internet, NIST can now readily share information inside and outside the institution through the NIST Virtual Library, online publications, data banks, and other resources. Interactions

\footnotetext{
NAMT, 1-8.

${ }^{42}$ Personal communication, Jackson, December 29, 2000.
} 
with customers have benefitted by allowing them to track artifacts via online databases as their artifacts progress through the agency's measurement services. NAMT projects have crossed divisional lines within NIST, as seen in Figure 25, to exploit the possibilities of IT and enhance services. More boundaries have dissolved with the development of SIMnet, a network of 12 national metrology laboratories of the Americas to support calibration and measurement of electrical quantities during international comparisons. This pilot project represents the important first step in using the IT capabilities of NAMT for delivery of international metrology services. ${ }^{43}$

Once MEL management had determined its next focus of activity, it commemorated its past in July 1995 with a formal ceremony closing the AMRF and opening the NAMT. ${ }^{4 t}$ As then-MEL director Jackson noted, the AMRF was "an enormously successful, well planned and conceived research program to improve US manufacturers' productivity and competitiveness by focusing attention on metrology and standards, the cornerstones of manufacturing., ${ }^{, 5}$ From MEL's experience in managing the AMRF came the skill to do large projects and involve many people from a range of backgrounds and interests in a collaborative way. This ability paved the way for MEL to spearhead the NAMT project and to assist NIST with the larger vision of applying IT to all of its work.

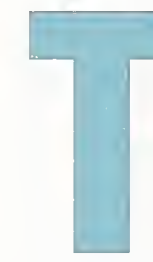

HE LEGACY OF THE AMRF'S ROBOTS AND MACHINE TOOLS dancing together in artful combinations continues in the people and their projects at NIST. Those individual people, who might have tapped on computer keys at $2 \mathrm{AM}$ before a big demonstration and strained every fiber in their brains to get a big lumbering robot to coordinate with a no-nonsense metal-cutting machine tool, continue to use these past experiences to make a difference in the manufacturing world of today. Those people, who knew intimately about the insides of the individual pieces of equipment and how to "trick" the equipment into doing the tasks needed, continue to work with industry and help develop the standards and interfaces for integrated manufacturing. Those people, who had the vision and motivating talents to convince more than two hundred scientists, along with upper management and other government entities, that the AMRF should be done and how, continue to dream up and explore the future research trends. And, those people, who believed in the vision and supported it in whatever ways they could, continue to search for avenues that might help American companies compete successfully in the global marketplace. Those people, who, as former Senate staffer Windham stated, had an amazing mixture of "brains, vision, and humility," ${ }^{46}$ and their new projects live on. The AMRF worked, and its legacy lives on because, as Windham noted, "there were some good people who cared about it and had the social and political skills to put coalitions together and make it work. My boss [Senator Hollings] would not have had the confidence that he had and continues to have in NIST, would not have assigned them programs involving hundreds of millions of new dollars unless he thought they were good people." ${ }^{, 47}$

\footnotetext{
${ }^{43}$ Ibid; MEL Program Review, May 5, 2000, unpaginated, File NAMT.

${ }^{4}$ Dave Stieren replaced John Meyer, who had resigned, as AMRF program manager and developed and directed the plan to close the facility.

Richard Jackson, typescript of his speech at the 1995 AMRF closing ceremonies, File AMRF Closing 1995, AMRF Files, NIST.

"Windham, interview, August 4, 2000. 


\section{Appendix 1}

\section{ACRONYMS}

ADACS Advanced Deburring and Chamfering System

Al Artificial Intelligence

AMRF Automated Manufacturing Research Facility

ANSI American National Standards Institute

ATP Advanced Technology Program

CAD Computer-Aided Design

CAM Computer-Aided Manufacturing

CAMP Cleveland Advanced Manufacturing Program

CDWS Cleaning and Deburring Workstation

CIM Computer Integrated Manufacturing

CIRP International Institution for Production Engineering Research

CMAC Cerebellum Model of Articulation Control

CME Center for Manufacturing Engineering

CMEPT Center for Mechanical Engineering and Process Technology

CMM Coordinate Measuring Machine

CNC Computer Numerical Control

CT Cooperative Technology

DARPA Defense Advanced Research Projects Agency

DNC Direct Numerical Control

DOD Department of Defense

HCS Hierarchical Control System

HCSE Hierarchical Control System Emulator

HWS Horizontal Workstation

ICAM Integrated Computer-Aided Manufacturing

IGES Initial Graphics Exchange Specification

IMDAS Integrated Manufacturing Data Administration System

IT Information Technology

IWS Inspection Workstation

FMC Flexible Manufacturing Center

GAO General Accounting Office
GM General Motors Corporation

GPO Government Printing Office

MAP Manufacturing Automation Protocol

$M^{3} \quad$ Molecular Measuring Machine

MEL Manufacturing Engineering Laboratory

MEP Manufacturing Extension Partnership

MHS Material Handling System

MSID Manufacturing Systems Integration Division

MTC Manufacturing Technology Center

MUM Mechanized Unmanned Manufacturing

NAMT National Advanced Manufacturing Testbed

NAS National Academy of Sciences

NASA National Aeronautics and Space Administration

NAVSUP Naval Supply Systems Command

NBS National Bureau of Standards

NEL National Engineering Laboratory

NIST National Institute of Standards and Technology

NIT National Institute of Technology

NC Numerical Control

PC Personal Computer

PDES Product Data Exchange using STEP

PEPCO Potomac Electric Power Company

RAMP Rapid Acquisition of Manufactured Parts

RCS Real-time Control System

SCRA South Carolina Research Authority

SRI Surface Roughness Instrument

STEP Standard for the Exchange of Product Model Data

TI Texas Instruments

TWS Turning Workstation

vWS Vertical Workstation 


\section{Appendix 2}

\section{AWARDS TO AMRF PROGRAM}

\begin{tabular}{lll} 
Award & Awarder & Staff Member(s) \\
\hline Gold Medal & U.S. Department of Commerce & $\begin{array}{l}\text { J. Albus (1986) } \\
\text { R. Hocken (1986) } \\
\text { P. Nanzetta (1987) }\end{array}$ \\
\hline Taylor Medal & $\begin{array}{l}\text { International Organization for } \\
\text { Production Engineering Research (CIRP) }\end{array}$ & R. Hocken \\
\hline F.W. Taylor Medal & Society of Manufacturing Engineers & R. Hocken \\
\hline $\begin{array}{l}\text { Engleberger Award for } \\
\text { Robotics }\end{array}$ & Robot Institute of America & J. Albus \\
\hline IR-100 Award-Drill-up & Industrial Research Magazine & \\
\hline $\begin{array}{l}\text { IR-100 Award-Error } \\
\text { Correction }\end{array}$ & Industrial Research Magazine & K. Yee, D. Blomquist \\
& & K. Lee, T. Charlton, J. \\
& & Shaver, R. Veale, B. \\
Borchardt, R. Liu, W.
\end{tabular}




\section{Appendix 3}

\section{STANDARDS FROM AMRF PROGRAM}

\section{In Place as of 1991}

\begin{tabular}{ll}
\hline Initial Graphics Exchange Specification ver. 1-4 & ANSI Y 14.26 M \\
\hline Characterization of Coordinate Measuring Machines & ANSI/ASME B89.1.12 \\
\hline Surface Texture & ANSI B46.1 - 1985 \\
\hline Automated Interchange of Technical Information & Department of Defense \\
\hline $\begin{array}{l}\text { Digital Representation for Communication of Product } \\
\text { Data Application Subsets }\end{array}$ & Department of Defense \\
\hline $\begin{array}{l}\text { Markup Requirements and Generic Style } \\
\text { Specification for Electronic Printed Output and } \\
\text { Exchange of Text }\end{array}$ & Department of Defense \\
\hline Raster Graphics Representation in Binary Format & NCSL \\
\hline $\begin{array}{l}\text { Digital Representation for Communication of } \\
\text { Illustration Data }\end{array}$ & NCSL \\
\hline CGM Application Profile & CALS, Department of Defense \\
\hline
\end{tabular}

\section{Being Developed as of 1991}

\begin{tabular}{ll}
\hline Models for Factory Architecture & ISO TC 184 SC 5 \\
\hline Industrial Automation & ANSI panel (IAPP) (Chair) \\
\hline Information \& Communication, Robots & RIA R15.04 Council (Chair) \\
\hline Robotics and Automation & IEEE R\&A Council (Chair) \\
\hline Robot Performance & RIA R15.05 \\
\hline Data Exchange Standards & ANSI X3 \\
\hline Manufacturing Automation Protocol & EIA \\
\hline Performance of Machining Centers & ANSI B5 TC52 \\
\hline Standard for the Exchange of Product Model Data & ISO TC 184 SC4 \\
\hline Remote Data Access & TC X3 H2.1 \\
\hline Interchange of Large Format Tiled Raster Documents & NCSL (Chair) \\
\hline
\end{tabular}




\section{Appendix 4}

\section{DONATIONS TO THE AMRF PROGRAM}

\begin{tabular}{ll} 
Company & Item \\
\hline Boeing Computer Services & Configuration Management Software \\
\hline Brown and Sharpe Mfg. Co. & $\begin{array}{l}\text { Computer Controlled Coordinate Measuring Machine } \\
\text { Validator CNC Coordinate Measuring Machine }\end{array}$ \\
\hline Carnegie Group & Knowledge Craft Expert Systems Tool Package \\
\hline Case Consulting & Dynamod Software \\
\hline CMX & Laser Interferometer System \\
\hline Computer Identics Corp. & Scan Star 50 (Laser Bar-code Scanner) \\
\hline Control Data & PC-IAST Software \\
\hline DACOM & PC-Leverage and Leverage Software \\
\hline Factrol & Scheduling Software \\
\hline Fafnir & Bearings \\
\hline Garlock Bearings & Bearings \\
\hline General Electric & Machine Tool Monitor \\
\hline Graphael & Emulator Software Package \\
\hline Hardinge Brothers & Object Oriented Software \\
\hline Harris Semiconductor Corp. & Two Hardinge Superslant CNC Turning Centers \\
\hline Hewlett-Packard & Plasma Cleaning System \\
& Refractometer \\
\hline Hitachi & HP 9845 Computer \\
\hline IBM & Scanning Electron Microscope \\
& IBM 7565 Industrial Robot with Series/1 Computer \\
& 7545 Industrial Robot \\
\hline ICONIX & 4381 Model P-12 (16 Megabyte) Computer \\
\hline Inland Motors & Various Peripherals and Software \\
\hline INTEL & RT CAD Computers (3) \\
\hline Kardex Systems, Inc. & Power Tools Software \\
\hline Kennametal, Inc. & Servo Motors \\
\hline & Software Development Systems \\
\hline & Industriever 8000 Vertical Storage/Retrieval System \\
\hline & Tool Setting Station \\
\hline & Tooling for Machine Tools \\
\hline
\end{tabular}




\begin{tabular}{|c|c|}
\hline Company & Item \\
\hline Lawrence Livermore Nat. Lab. & Zero Dur. Straight Edge \\
\hline Los Alamos National Lab. & Air Bearing Spindle \\
\hline Meta Software & Meta Software \\
\hline Metcut Research Associates & Tooling Database \\
\hline $\begin{array}{l}\text { Mitotoyo (MTI) } \\
\text { (A Japanese Measuring Equipment Co.) }\end{array}$ & Measuring Machine (Computer Assisted) \\
\hline Monarch Machine Tool Co. & VMC 75 CNC Vertical Machining Center \\
\hline MOOG, Inc. & Hydraulic Valves \\
\hline New Hampshire Ball Bearings & Bearings \\
\hline NSK Corporation & Precision Linear Bearings \\
\hline Ontologic & OB2 Object Oriented Database \\
\hline Optische Werke G. Rodenstock & Head for Rodenstock Optical Surface Gage \\
\hline Oracle Corp. & Database Software \\
\hline Pratt And Whitney & GMAP Software \\
\hline Prime/CV & $\begin{array}{l}\text { PDM } \\
\text { CAD/CAM System }\end{array}$ \\
\hline Qint Database Systems Corp. & Tina Software \\
\hline Rank Taylor Hobson (British Co.) & Surface Roughness Measuring Apparatus \\
\hline Renishaw, Inc. & Dimensional Probes and Accessories \\
\hline Rodenstock Precision Optics & EPROMS for Scanning Software \\
\hline Sandia & Shock Apparatus \\
\hline Savoir & Al Software \\
\hline SDRC (Structural Dynamics Research Corp.) & Ideas (CAD Software) \\
\hline Serviologic & Gemstone Object Oriented Database \\
\hline Sheffield Manufacturing & Computer Controlled Coordinate Measuring Machine \\
\hline Software Architecture \& Eng., Inc. & KES Expert Systems Software Tool Package \\
\hline Sony Corp. of America & Digital Audio Recorder \\
\hline Tandem Computer & VLX Non-stop Computer Systems \\
\hline Texas Instruments & TI Explorer AI Machine (2) \\
\hline Thomas Industries Inc. & Ballnut Linear Drives \& Linear Ball Bushings \\
\hline Valeron Corporation & $\begin{array}{l}\text { Tooling for Horizontal Machining Ctr. } \\
\text { 3-D Probe for Sensing }\end{array}$ \\
\hline Veeder Root & Sensors \\
\hline Westinghouse Unimation & 2000 B Unimate Robot \\
\hline Xerox & Al Workstations \\
\hline
\end{tabular}

TOTAL: $\$ 12,000,000$ 


\section{Appendix 5}

\section{INDUSTRIAL RESEARCH ASSOCIATES OF THE AMRF}

Acme-Cleveland Corporation

Allen-Bradley Company

Arthur Andersen \& Co.

Bendix Corporation, Kansas City Div.

Boeing

Brown \& Sharpe Manufacturing

Case Consulting

Cincinnati Milacron, Inc.

CMX Co.

DACOM

E. Fjeld Company, Inc.

EDAX International, Inc.

Electronic Measuring Devices, Inc.

Factrol, Inc.

FMC Corp./Northern Ordinance Div.

GCA Corporation

GCA Corporation/Tropel Div.

General Dynamics, Pomona Div.

General Electric Co.

Hardinge Brothers, Inc.

Hewlett Packard

Honeywell, Inc.

Hurco
IBM

Kennametal, Inc.

Lockheed Missiles and Space Co.

Management Collaborative Group

Mare Island Naval Shipyard

Martin Marietta Corp.

Meridian Corp.

Metcut Research Associates, Inc.

Monarch Machine Tool Co.

NASA

National Tooling and Machining Assoc.

Ontologic, Inc.

Qint Database Systems Corp.

Science Applications, Inc.

Structural Dynamics

Tandem Computers, Inc.

Texas Instruments, Inc.

Transitions Research Corporation

Vickers Instruments

VLSI Standards, Inc.

Warner and Swasey Co., Sheffield Div.

Westinghouse

White-Sundstrand 


\section{Appendix 6}

\section{PATENTS FROM AMRF PROGRAM}

\begin{tabular}{ll} 
Name & Author(s) \\
\hline "Split-Rail" Parallel Gripper & Vranish, Bunch, Johns \\
\hline Inclined Contact Recirculating Roller Bearing & Slocum \\
\hline Multi-Port Hydraulic Commutator Valve & Slocum, Peris \\
\hline "Quick Change" System for Robots & Vranish \\
\hline Robot End Effector & Slocum, Jurgens \\
\hline Pipelined Image Processors & Kent \\
\hline Magnetoresistitive Skin for Robots & Vranish, Schwee, Goetz \\
\hline Rotating Tool wear Monitoring Apparatus & Yee, Blomquist \\
\hline Interferometric Angle Measuring Device & Lau \\
\hline Automatic Laser Interferometer Tracking Device & Lau, Hocken \\
\hline Device of In-line Measurement of Lathe Cutting Tools & Peris \\
\hline Method and Mechanism for Fixturing Objects & Slocum, Peris \\
\hline Method and Mechanism for Inserting Parts & Slocum, Peris \\
\hline Local Buffer Storage for Robotic Workstation & Reisenauer, Gaver, Slocum \\
\hline Ultrasonic Device to Monitor Surface Roughness & Blessing, Eitzen \\
and/or Tool Wear & \\
\hline Automated Collet Changer & Reisenauer, Lee, Jurgens \\
\hline Multiple Actuator Hydraulic System & Slocum, Peris \\
\hline Rotary Control Valve & \\
\hline
\end{tabular}




\section{Appendix 7}

\section{PRODUCTS FROM AMRF PROGRAM}

\begin{tabular}{lll} 
Name of Product & Company & Description \\
\hline CMM Accuracy & Sheffield & Software Error Correction \\
\hline Drill-Up & Valeron & Drill Wear Detector \\
\hline Drill-Up & Technovations & Drill Wear Detector \\
\hline Validator CMM & Brown \& Sharpe & Software Correction \\
\hline Apollo CMM & Sheffield & Software Correction \\
\hline KV Quick Change Tools & Kennametal & Tooling System \\
\hline Quick Change & Medical Robotics & Quick Change Wrist \\
\hline Quick Change & Milacron & Quick Change Wrist \\
\hline Gripper & Lord Corp. & Robot Gripper \\
\hline Error Correction & Hardinge & Lathe Error Correction \\
\hline Error Correction & Brown \& Sharpe & Mill Error Correction \\
\hline Tool Setting & Hardinge & On Machine Tool Setting \\
\hline Robot Vision & Automatix & Structured Light \\
\hline PIPE & ASPEX & Image Processor \\
\hline
\end{tabular}

\section{Subsystems from AMRF Program}

\begin{tabular}{ll} 
Name of Subsystem & Location \\
\hline Servo Vise & Goodyear Tire \\
\hline Emulator (HCSE) & General Electric, BB \& N \\
\hline Controllers & Boeing/Computer Services, FMC, Timken \\
\hline Process Planner & Bendix Kansas City, Texas Instruments \\
\hline Facility Software & South Carolina Research Authority \\
\hline Robot Vision & Northrup \\
\hline IMDAS & Lehigh \\
\hline Robot Vision & Digital Signal \\
\hline Robot Control System & Honeywell, Martin Marietta, Allen Bradley, \\
\hline CAD Directed Inspection & Rensselaer Polytechnic Institute \\
\hline Feature Driven Machinery & Rensselaer Polytechnic Institute \\
\hline
\end{tabular}




\section{Appendix 8}

\section{THESIS RESEARCH ON AMRF PROGRAM}

\begin{tabular}{|c|c|c|}
\hline Title & School & Degree \\
\hline $\begin{array}{l}\text { "A Plan to Transition the Automated Manufacturing Research } \\
\text { Facility at the National Institute of Standards and Technology } \\
\text { into Future Operations." }\end{array}$ & Univ. of Maryland & MA \\
\hline $\begin{array}{l}\text { "A General Methodology For Machine Tool Accuracy } \\
\text { Enhancement, Theory, Application, and Implementation" }\end{array}$ & Purdue University & Ph.D. \\
\hline $\begin{array}{l}\text { "Sensor System Design to Determine Position and Orientation } \\
\text { of Articulated Structures" }\end{array}$ & MIT & Ph.D. \\
\hline $\begin{array}{l}\text { "Study of Continuous/Discontinuous Chip Formation Using } \\
\text { Acoustic Emission Signal Analysis" }\end{array}$ & Berkeley & Ph.D. \\
\hline $\begin{array}{l}\text { "Robot Gripper Control System Using PVDF Piezoelectric } \\
\text { Sensors" }\end{array}$ & VPI & MS \\
\hline "Methods of Detecting Wear of End Mills in Three Steels" & Johns Hopkins & MS \\
\hline "Quick Change Wrist with Sensor Feedback" & George Washington & MS \\
\hline "NC Verification Using Z-Trees" & George Washington & MS \\
\hline "Analysis of a Tool Setting Station for Turning Centers" & Purdue & MS \\
\hline "Dynamic Approach to Modeling for NC Verification" & Purdue & MS \\
\hline $\begin{array}{l}\text { "Tool Nose Radius Deviation Error Compensation Simulation } \\
\text { and Implementation" }\end{array}$ & Berkeley & MS \\
\hline $\begin{array}{l}\text { "Due-Date Based Performance Measures in Dynamic } \\
\text { Stochastic Manufacturing Systems" }\end{array}$ & Cornell & Ph.D. \\
\hline $\begin{array}{l}\text { "An Intelligent Notification System for Complex Physical } \\
\text { Processes" }\end{array}$ & George Washington & MS \\
\hline "Verifications Systems" & Univ. of Kansas & MS \\
\hline "Prototype Flexible Fixture for Prismatic Parts" & Univ. of Kansas & MS \\
\hline "Work on HERB" & Univ. of Kansas & MS \\
\hline
\end{tabular}




\section{Appendix 9}

\section{ACADEMIC CONNECTIONS OF THE AMRF PROGRAM}

Catholic University

Johns Hopkins

Lehigh

Penn State

SUNY (Utica)

University of California

University of Kansas

University of Illinois

University of Wisconsin

Stanford University

University of Utah

Boston University

University of Puerto Rico

University of Texas

University of South Carolina

Cleveland State University

Rensselaer Polytechnic Institute

Carnegie Mellon University

University of Arizona
George Washington University

Cooper Union

MIT

Purdue

Tennessee Tech.

University of Florida

University of Maryland

University of Virginia

Virginia Tech.

Cornell University

University of Tennessee

Case Western Reserve University

University of Pittsburgh

Marshall University

University of North Carolina - Charlotte

Michigan Technological University

Brigham Young University

University of New Hampshire 


\section{Appendix 10}

\section{PERSONAL INTERVIEWS}

In conjunction with the researching and writing of this history, the author conducted thirty-five interviews with people prominent in the history of the Automated Manufacturing Research Facility. The author wishes to thank these individuals for participating in these interviews. These interviews are listed below, along with the date of each interview. All interviews have been roughly transcribed. The National Institute of Standards and Technology retains custody of the audiotapes and rough transcriptions. Additional interviews with John Simpson, John Lyons, and Ernest Ambler are located in the NIST Archives.

James Albus, February 25, 2000

Anthony Barbera, May 22, 2000

Edward J. Barkmeyer, June 9, 2000

David Bettwy, July 14, 2000

Howard M. Bloom, March 3, 2000 and April 7, 2000

Thomas Charlton, May 8, 2000

M. Alkan Donmez, May 12, 2000

John M. Evans, February 18, 2000

Cita M. Furlani, March 24, 2000

Robert J. Hocken, March 3, 2000

Theodore Hopp, June 30, 2000

Al Jones, May 19, 2000

Ray Kammer, June 16, 2000

Ernest W. Kent, April 28, 2000

Roger Kilmer, July 28, 2000

Thomas R. Kramer, April 14, 2000

Robert Lach, July 21, 2000

Kang Lee, April 7, 2000
Steve Linder, June 23, 2000

Mark Luce, June 2, 2000

John W. Lyons, July 28, 2000

John W. McInnis, May 5, 2000

Charles McLean, June 2, 2000

Mary J. Mitchell, May 5, 2000

Roger Nagel, February 28, 2000

Philip Nanzetta, February 20, 2000

Richard J. Norcross, August 25, 2000

William G. Rippey, March 10, 2000

Harry Scott, June 16, 2000

John A. Simpson, February 25, 2000

Dennis A. Swyt, March 10, 2000

E. Clayton Teague, July 28,2000

Thomas E. Wheatley, May 26, 2000

Pat Windham, August 4, 2000

Russell D. Young, June 30, 2000 


\section{BIBLIOGRAPHY}

\section{Primary Sources}

Primary source materials consulted for this history resided at the National Institute of Standards and Technology (NIST). These records included:

- Automated Manufacturing Research Facility (AMRF) Files housed in the Manufacturing Engineering Laboratory (MEL) laboratory office. The files span the entire 1980-1995 chronological period of the AMRF and include correspondence, memoranda, chron files, annual reports, meeting outlines, technical reports, news clippings, press releases, photographs, slides, videos, posters, and other related materials. Oral history tapes and rough transcriptions from interviews conducted for writing this history are deposited with this collection.

- NIST Archives materials pertaining to the AMRF include biographical files on key personnel involved in AMRF activities, transcripts of oral history interviews, and photographs

- NIST Library materials pertaining to the AMRF include National Bureau of Standards (NBS) and NIST Annual Reports, congressional hearings, public laws, and NBS and NIST internal reports and other technical papers.

\section{Secondary Sources}

Albus, James S. Brains, Behavior, and Robotics. Peterborough, NH: BYTE Books, 1981.

"AMRF Gears Up for Full Operation," Modern Materials Handling (December 1986).

Ashley, Steven. "Mini-machining Cell." American Metal Market Metalworking News (April 20, 1981). 10, 16.

"The AM Award: Dr. John Simpson." American Machinist and Automated Manufacturing (December 1986): 58-65

Barkmeyer, Edward and Jane Lo. Experience with IMDAS in the Automated Manufacturing Research Facility. NISTIR-89-4132. Gaithersburg, MD: NIST, 1989.

Baum, Michael. "Automation 'Czar' Receives Presidential Award.” Commerce People (April 1986): 8.

-----. "Standard Interfaces Key to Factory Automation." NBS Research Reports (October 1984), 6-10.

Behr, Peter. "Even in R\&D, Standards Bureau Measuring Up." Washington Post (March 30, 1981), Washington Business, $1,7$.

Belanger, Dian Olson. Enabling American Innovation: Engineering and the National Science Foundation. West Lafayette, IN: Purdue University, 1998.

Bergstrom, Robin P. "Drilling Precision Stamp Cylinders at NBS." Manufacturing Engineering (April 1984): 76-79.

Blake, Peter L., ed. Advanced Manufacturing Technology. New York: North-Holland Publishing Company, 1980.

Bortz, Alfred B. "Joseph Engelberger: The Father of Industrial Robots Reflects on His Progeny." Robotics Age (April 1985): 15-21.

"Boosting Productivity by Investing in Research." Washington Star (February 27, 1987), A-12.

Carey, John. "For Manufacturers, a Taste of High-Tech Medicine." Business Week (April 30, 1990): 113. 
Clem, Mike. "Engineering Lab in Gaithersburg Does Research Unique in Nation," Frederick News-Post (November 21, 1985).

Cochrane, Rexmond C. Measures for Progress: A History of the National Bureau of Standards. Washington, DC: US Department of Commerce, 1966; reprint, Arno Press, Inc., 1976.

Cohen, Paul R. and Edward A. Feigenbaum, eds. The Handbook of Artificial Intelligence. Vol. 3. Los Altos, CA: William Kaufmann, Inc., 1982.

"Computers with Muscle: A Fully Automated, Flexible Machine Shop." Computers in Mechanical Engineering (January 1984): 4, 6.

Dallas, Daniel B. "The Advent of the Automatic Factory." Manufacturing Engineering (November 1980): 6676

Donmez, Alkan M., et al. The Turning Workstation in the AMRF. NBSIR 88-3749. Gaithersburg, MD: NBS, 1988.

Dorf, Richard C. Robotics and Automated Manufacturing. Reston, VA: Reston Publishing Company, Inc., 1983.

Furlani, Cita M., Ernest W. Kent, Howard M. Bloom, and Charles R. McLean. "The Automated Manufacturing Research Facility of the National Bureau of Standards." Paper presented at the Summer Computer Simulation Conference, Vancouver, BC, Canada, 1983.

Fusaro, Dave. "Seven Defense Contractors Incorporate PDES." Metalworking News (February 29, 1988), 5, 14.

Giffi, Craig, Aleda V. Roth, and Gregory M. Seal. Competing in World-class Manufacturing: America's $21^{\text {st }}$ Century Challenge. Homewood, IL: Business One Irwin, 1990.

Graham, Bradley. "Productivity Problems Outlined." Washington Post (October 4, 1978), C1-C2.

-----. "U.S. Productivity: Golden Days Over." Washington Post (September 10, 1978), F5.

Gunn, Thomas G. Manufacturing for Competitive Advantage: Becoming a World Class Manufacturer. Cambridge, MA: Ballinger Publishing Company, 1987.

Hocken, Robert J. "NBS Building Facility for Research into Problem of Automating Small Machine Shops." Industrial Engineering (April 1982).

Hocken, Robert J. and Philip Nanzetta. "Dimensional Metrology at the National Bureau of Standards." The Physics Teacher 21:8 (November 1983): 506-13.

-----. "Research in Automated Manufacturing at NBS." Manufacturing Engineering (October 1983): 68-69.

Hogue, Cheryl. "Robots into the Groove at Bureau of Standards." Montgomery Journal (November 21, 1985).

Jackson, Richard H. F., ed. Manufacturing and Automation Systems: Techniques and Technologies: Three Pillars of Manufacturing Technology, vol. 45 of Control and Dynamic Systems: Advances in Theory and Applications, edited by C. T. Leondes. San Diego, CA: Academic Press, Inc., 1992.

Jones, Albert T. and Charles R. McLean. "A Proposed Hierarchical Control Model for Automated Manufacturing Systems." Journal of Manufacturing Systems 5 (1986): 15-26.

Joyce, Christopher. "Factories Will Measure as They Make." New Scientist (September 4, 1986): 46-49

Kemmerer, Sharon J., ed. STEP: The Grand Experience. NIST SP 939. Gaithersburg, MD: NIST, 1999.

Khermouch, Gerry. "Automated Workstation Interests Navy." American Metal Market/Metalworking News (December 22, 1986): 7-8.

Kramer, Thomas R. and Jau-shi Jun. "Software for an Automated Machining Workstation." Paper presented at the International machine Tool Show Technical Conference, Chicago, IL, September 1986.

Lawrence Livermore Laboratory. Machine Tool Task Force. Robert J. Hocken, Working Group Chairman. Technology of Machine Tools. Vol 5 of Machine Tool Accuracy. UCRL-52960-5. Livermore: University of California, 1980. 
Lee, Kang B. "Computer-Controlled Fastener Manufacturing Workstation." Society of Automotive Engineers Technical Paper Series. 941719. Paper presented at the International Off-Highway and Powerplant Congress and Exposition, Milwaukee, WI (1994).

McLean, Charles, Mary Mitchell, and Edward Barkmeyer. "A Computer Architecture for Small-Batch Manufacturing." IEEE Spectrum (May 1983): 59-64.

Meade, William P. The National Bureau of Standards' Automated Manufacturing Research Facility (AMRF): An Analysis of its Impact. Chapel Hill, NC: Management Collaborative Group, 1984.

Merchant, M. Eugene. "The Coming of the Automatic Factory." Manufacturing Engineering (March 1980): 69-77.

----. "Future Trends in Manufacturing - Toward the Year 2000." Annals of the CIRP 25:2 (1976): 473-75.

"Metalworking Electronics," Machine and Tool Blue Book (April 1983).

Moncarz, Howard T., Stephen A. Osella, Bruce Borchardt, and Ralph Veale. Operations Manual for the Inspection Workstation. NBSIR 88-3766 (Gaithersburg, MD: NBS, 1988).

Murphy, Karl N. and Frederick M. Proctor. "An Advanced Deburring and Chamfering System." Paper presented at the Third International Symposium on Robotics and Manufacturing, British Columbia, Canada, July 1990.

Nanzetta, Philip. "Update: NBS Research Facility Addresses Problems in Set-Ups for Small Batch Manufacturing." Industrial Engineering (June 1984): 68-73

Norcross, Richard J. "A Control Structure for Multi-Tasking Workstations." Proceedings of the 1988 IEEE International Conference on Robotics and Automation. Philadelphia, PA, 1988.

Passaglia, Elio with Karma A. Beal. A Unique Institution: The National Bureau of Standards 1950-1969. Washington, DC: Government Printing Office, 1999.

Pellerin, Cheryl. "Scientists Help American Manufacturers Build Factory of the Future." Washington Technology (January 22, 1987), 14-15.

Reintjes, J. Francis. Numerical Control: Making a New Technology. New York: Oxford University Press, 1991.

Rooks, Brian W. "Encouraging Industry to Invest in Future Technology." Industrial Robot 13 (March 1986): 29-32.

Simpson, John A. "Automation Research at NBS: Seeking Generic Technology for the Automated Shop." NBS Dimensions 65 (May/June 1981): 3-7.

Simpson, J. A., R. J. Hocken, and J. S. Albus. "The Automated Manufacturing Research Facility of the National Bureau of Standards." Journal of Manufacturing Systems 1 (1982): 17-32.

Society of Manufacturing Engineers. The National Role and Importance of Manufacturing Engineering and Advanced Manufacturing Technology. May 1978.

"Standard Data Formats: Transferring Part Designs between Systems." NBS Research Reports (October 1984): 10.

"Standard for Performance Evaluation of Coordinate Measuring Machines." Industrial News (October 1985).

Steeds, William. A History of Machine Tools 1700-1910. London: Oxford University Press, 1969.

Stieren, David C. "A Plan to Transition the Automated Manufacturing Research Facility at the National Institute of Standards and Technology into Future Operations." MA Thesis, University of Maryland University College, 1995.

"Tool Handling Advancements." Robotics Today (1986).

U.S. General Accounting Office. Report to the Congress by the Comptroller General of the United States: Manufacturing Technology - A Changing Challenge to Improved Technology. LCD-75-436. Washington, DC: GPO, 1976.

-----. Opportunities and Constraints for Expanding Use of Research Facilities at the National Bureau of Standards. GAO/RCED-85-55. Washington, DC: GPO, 1985. 
U.S. House Committee on Science and Technology, Subcommittee on Science, Research and Technology. 1981 National Bureau of Standards Authorization: Hearings. 96 $6^{\text {th }}$ Cong., 2d sess., February 1980.

-----. The National Bureau of Standards: A Review of Its Organization and Operations 1971-1980. 97 Cong., $1^{\text {st }}$ sess., May 1981.

U.S. House Committee on Science, Space, and Technology. Subcommittee on Science, Research, and Technology. Hearing on 1988 National Bureau of Standards Authorization. $100^{\text {th }}$ Cong., $1^{\text {st }}$ sess., March 3, 1987.

U.S. National Research Council. Reactions of Small Machine Shop Owners to the Automated Manufacturing Research Facility of the National Bureau of Standards. Washington, DC: National Academy Press, 1985.

----- 1992 Proposal Evaluation for the Manufacturing Technology Centers Program. Washington, DC: National Academy Press, 1992.

U.S. Senate Subcommittee of the Committee on Appropriations. Departments of Commerce, Justice, State, the Judiciary, and Related Agencies Appropriations for Fiscal Year 1989; Hearings on H. R. 4782. $100^{\text {th }}$ Cong., 2 d sess., May 12, 1988.

U.S. Senate Committee on Commerce, Science, and Transportation. Department of Commerce Technology Programs Authorization: Hearing. 100 Cong., $1^{\text {st }}$ sess., June 6, 1989.

U.S. Senate Committee on Commerce, Science, and Transportation. Government Role in Civilian Technology: Hearing. 102d Cong., 2d sess., March 26, 1992.

Wilson, Frank W. Numerical Control in Manufacturing. New York: McGraw-Hill Book Company, 1963.

Wright, Paul Kenneth and David Alan Bourne. Manufacturing Intelligence. Reading, MS: Addison-Wesley Publishing Company, Inc., 1988.

Yang, Charles and Kang Lee. "Integration of Real-Time Process Planning for Small-Batch Flexible Manufacturing." Paper submitted to the International Association of Science and Technology for Development, Twelfth International Symposium, Robotics and Manufacturing. Around 1990. 


\section{About the Author}

Joan M. Zenzen, an independent public historian, holds a Ph.D. in American Studies from the University of Maryland. She has written about promotional images of the western national parks; National Park Service administration; nuclear production reactors at Hanford, Washington; and nuclear waste practices at many US Department of Energy sites. Her book, Battling for Manassas: The Fifty-Year Preservation Struggle at Manassas National Battlefield Park (Penn State University Press, 1998), examined the heated issue of use versus preservation at this national battlefield site in northern Virginia. 


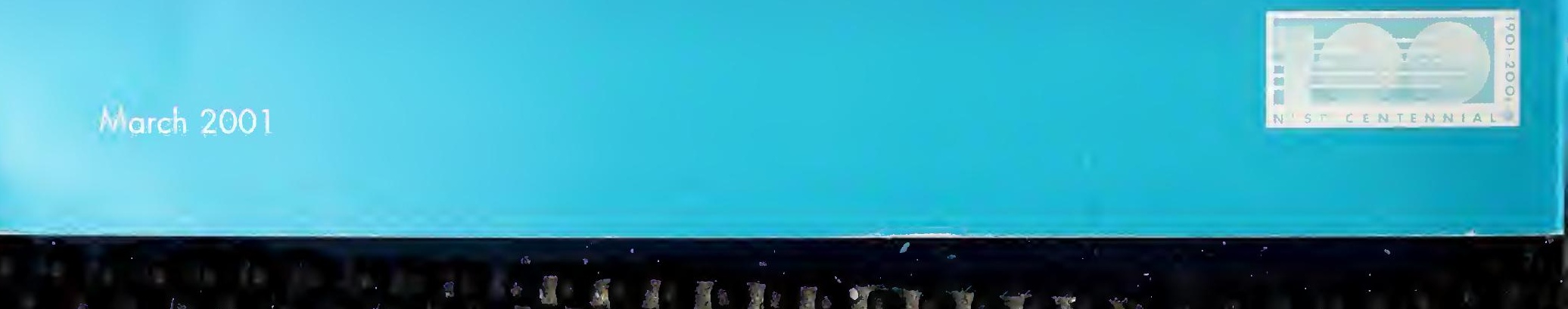